Universidade de São Paulo

Escola Superior de Agricultura "Luiz de Queiroz”

Identificação de polimorfismos no gene da leptina e de seu receptor em duas linhagens de aves e associação com características de desempenho e carcaça

Kerli Ninov

Dissertação apresentada para obtenção do título de Mestre em Agronomia. Área de concentração: Ciência Animal e Pastagens

Piracicaba 


\section{Kerli Ninov}

Licenciado e Bacharel em Ciências Biológicas

Identificação de polimorfismos no gene da leptina e de seu receptor em duas linhagens de aves e associação com características de desempenho e carcaça

Orientador:

Prof. Dr. LUIZ LEHMANN COUTINHO

Dissertação apresentada para obtenção do título de Mestre em Agronomia. Área de concentração: Ciência Animal e Pastagens

Piracicaba 
Dados Internacionais de Catalogação na Publicação (CIP) DIVISÃO DE BIBLIOTECA E DOCUMENTAÇÃO - ESALQ/USP

Ninov, Kerli

Identificação de polimorfismos no gene da leptina e de seu receptor em duas linhagens de aves e associação com características de desempenho e carcaça / Kerli Ninov. - Piracicaba, 2006.

90 p. : il

Dissertação (Mestrado) - - Escola Superior de Agricultura Luiz de Queiroz, 2006. Bibliografia.

1. Aves de corte 2. Aves poedeiras 3. Carcaça 4. Genes 5. Hormônios peptidícos 6. Linhagens animais 7. Melhoramento genético animal 8. Polimorfismo I. Título

CDD 636.5

"Permitida a cópia total ou parcial deste documento, desde que citada a fonte - O autor" 


\section{DEDICO}

A minha mãe Dirlei e ao meu irmão Márcio, pela compreensão, incentivo e carinho

\section{OFEREÇO}

Ao meu pai Oscar (in memorian) 


\section{AGRADECIMENTOS}

Ao Prof. Dr. Luiz Lehmann Coutinho, pela orientação e ensinamentos recebidos.

À Dra. Mônica Corrêa Ledur, pela orientação, paciência, apoio e amizade.

À FAPESP, pela concessão da bolsa de estudo.

À Embrapa Suínos e Aves, pelo apoio financeiro ao desenvolvimento deste trabalho.

Aos amigos e profissionais da Embrapa Suínos e Aves.

Aos técnicos do Laboratório de Biotecnologia Animal, Jorge e Nirlei pelo apoio e amizade durante estes anos.

À amiga e secretária Giovana de Oliveira, pelo atendimento e atenção recebidos.

Aos amigos Carla dos Anjos, Jane Gabriel, Mateus Patrício e Kátia Nones, pela ajuda e troca de idéias nas diferentes fases desta dissertação.

À amiga Helena, pelos conselhos e pelo ombro amigo, sempre me apoiando e me animando nos momentos difíceis.

Ao amigo Millor, pelo apoio durante estes anos.

Aos demais amigos do Laboratório de Biotecnologia Animal, pela convivência e troca de experiências durante estes anos.

Aos amigos Adriana (Dri), Aline (Esmerê), Ana Paula (Flipper), Erik, Graziela, Marina, Naiane, Priscilla e Roberta, pela paciência, amizade e pelos momentos de descontração.

A todos que de alguma maneira contribuíram para a realização deste trabalho. 


\section{SUMÁRIO}

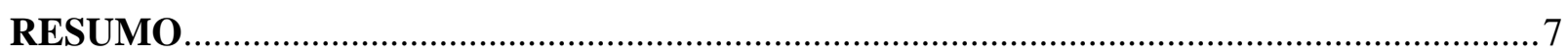

ABSTRACT

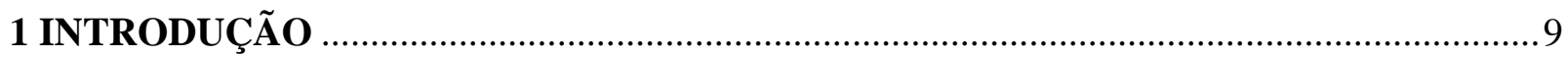

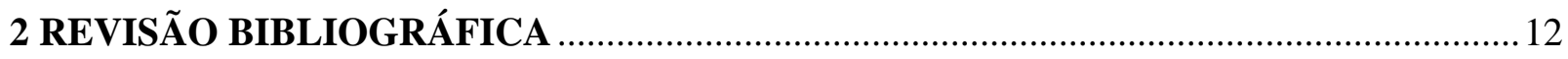

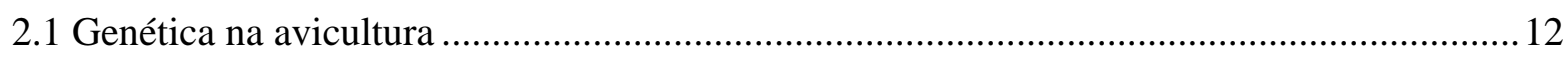

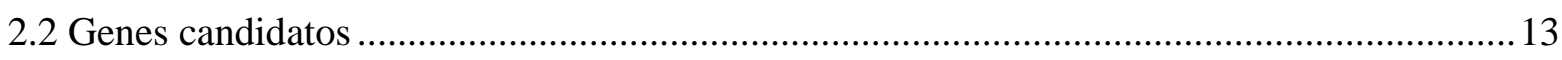

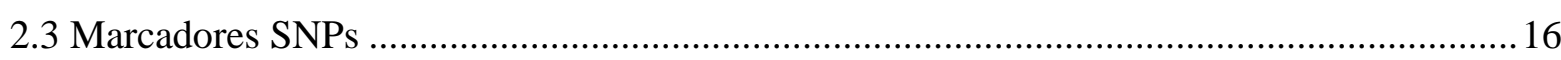

2.4 Caracterização do gene da leptina e de seu receptor ..........................................................18

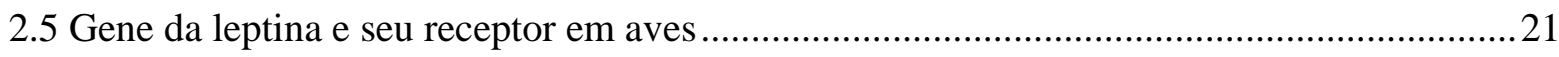

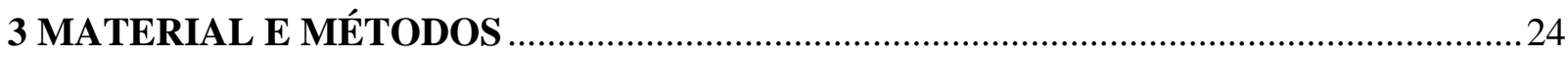

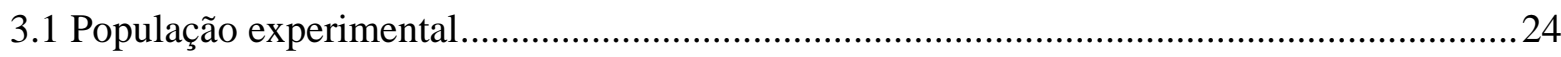

3.2 Coleta de dados fenotípicos e de amostras de sangue ........................................................26

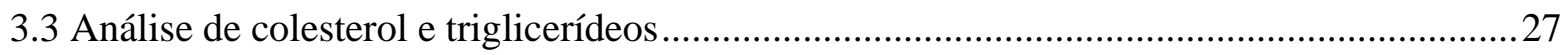

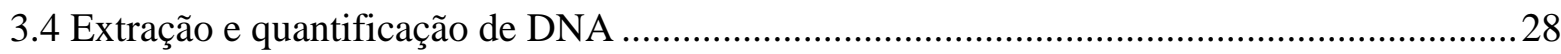

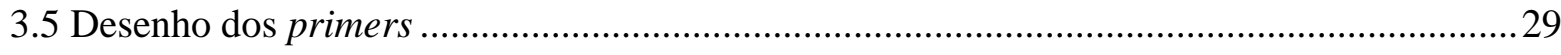

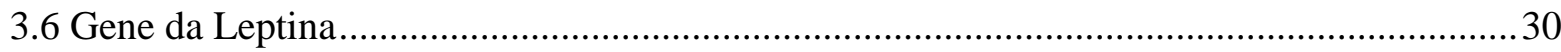

3.6.1 Otimização das condições de amplificação por PCR ....................................................... 30

3.6.2 Extração e quantificação de RNA total ............................................................................ 31

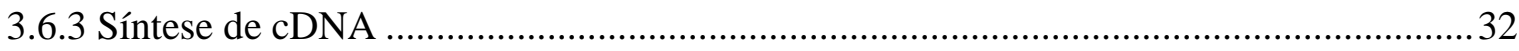

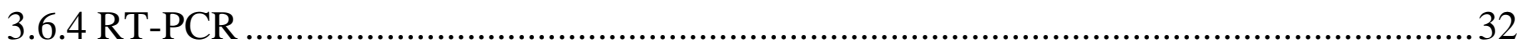

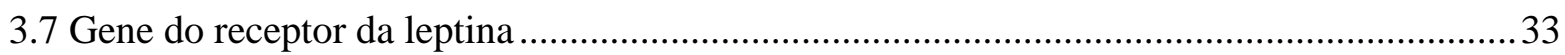

3.7.1 Otimização das condições e amplificação por PCR ........................................................33

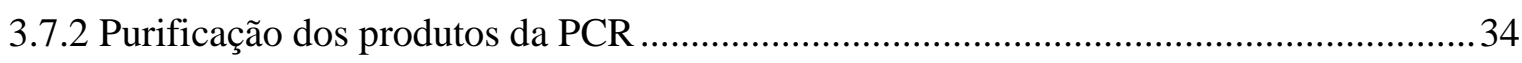

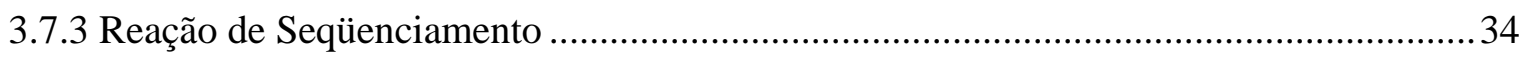

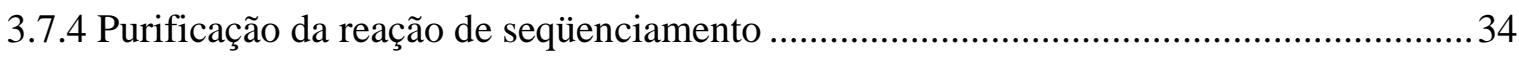

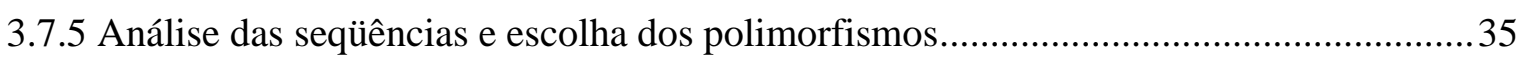

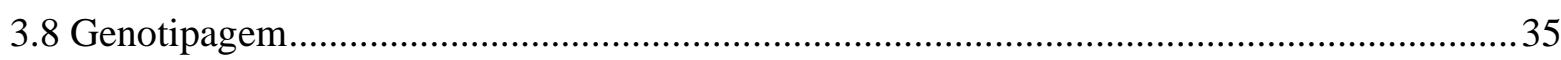

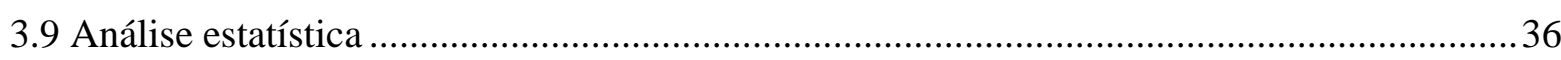

3.10 Localização do gene do receptor da leptina no mapa de ligação da Embrapa .....................37 


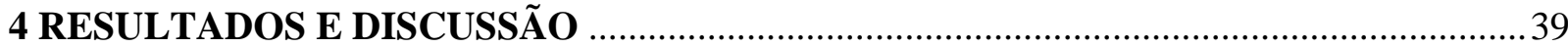

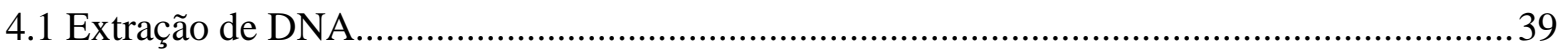

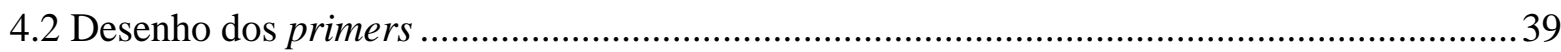

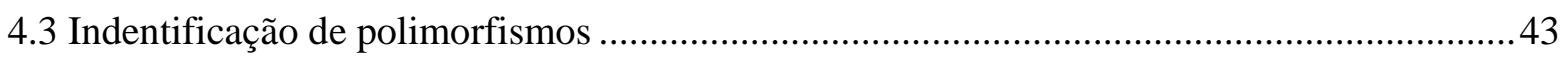

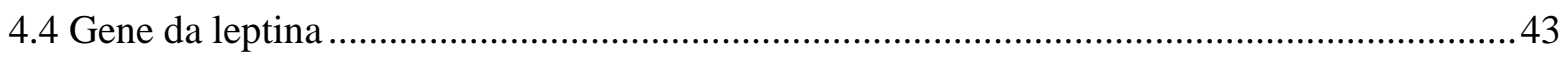

4.4.1 Otimização das condições e amplificação por PCR ........................................................ 43

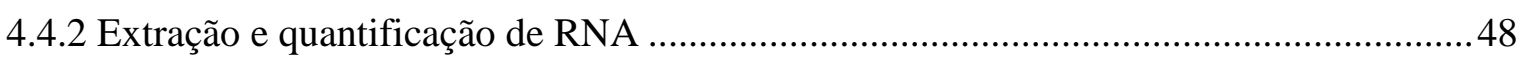

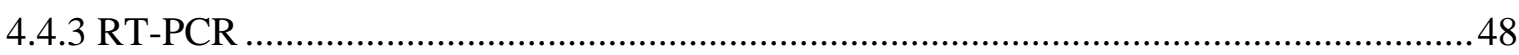

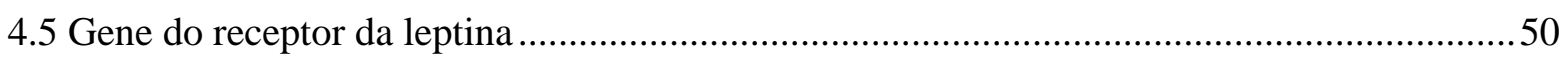

4.5.1 Otimização das condições e amplificação por PCR ........................................................50

4.5.2 Purificação dos produtos da PCR .................................................................................. 51

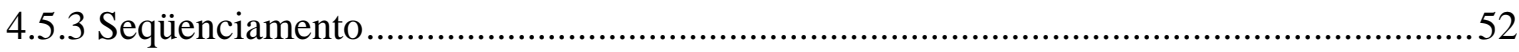

4.5.4 Análise das seqüências e escolha dos polimorfismos........................................................52

4.6 Genotipagem de polimorfismos no gene RLep …...............................................................55

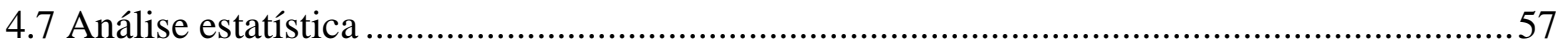

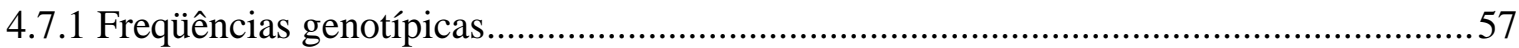

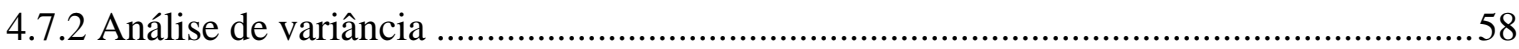

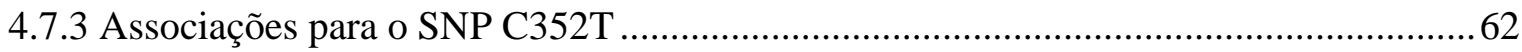

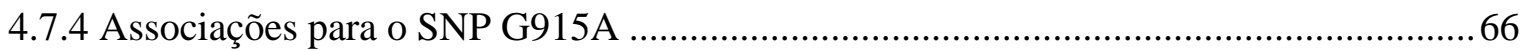

4.8 Efeito de polimorfismos no gene do receptor da leptina .......................................................69

4.9 Localização do gene do receptor da leptina no mapa de ligação da Embrapa ....................... 70

4.10 QTLs mapeados no cromossomo 8 de Gallus gallus .......................................................... 71

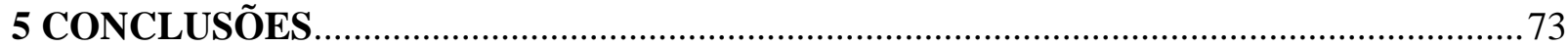

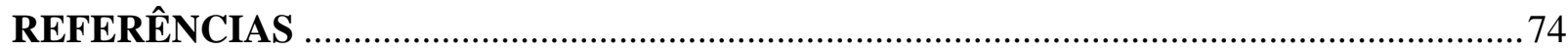

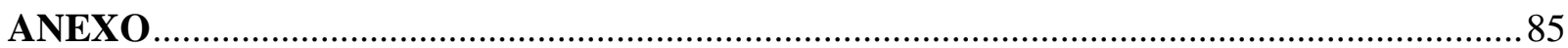




\title{
RESUMO
}

\section{Identificação de polimorfismos no gene da leptina e de seu receptor em duas linhagens de aves e associação com características de desempenho e carcaça}

\begin{abstract}
A tendência da indústria em produzir alimentos mais saudáveis, com menos gordura vem aumentando sensivelmente. O desafio do melhoramento nos dias atuais é melhorar a qualidade da carcaça dos frangos juntamente com a redução nos teores de gordura, que é uma exigência do mercado consumidor. A leptina é um hormônio polipeptídico secretado principalmente pelo tecido adiposo com um importante papel na regulação da ingestão de alimentos, metabolismo de energia e reprodução. O gene da leptina e seu receptor vem sendo objeto de intensa investigação representando excelentes genes candidatos para deposição de gordura na carcaça nos programas de seleção assistida por marcadores. A função desses genes tem sido intensamente estudada em mamíferos, porém, em aves poucos estudos foram realizados. O presente trabalho teve como objetivo investigar a ocorrência de polimorfismos no gene da leptina e de seu receptor em galinhas, e avaliar os efeitos desses polimorfismos sobre características de desempenho e carcaça. Duas linhagens de aves, uma de corte (TT) e uma de postura (CC) foram utilizadas para desenvolver a população referência F2 empregada no presente estudo. A polução referência foi desenvolvida no sistema de Melhoramento Genético de Aves da Embrapa Suínos e Aves, em Concórdia/SC. Foram desenhados primers para amplificar o gene da leptina e os íntrons 8 e 19 do do gene do receptor da leptina. Entretanto, após diversas tentativas não foi possível amplificar o DNA genômico e cDNA do gene da leptina. No íntron 8 do gene do receptor da leptina o SNP C352T foi genotipado por seqüenciamento em 247 animais da população F2. O alelo $\mathrm{T}$ foi associado ao maior rendimento de carcaça $(\mathrm{P}=0,0165)$, rendimento de peito ( $\mathrm{P}=0,0137)$, gramas de proteína bruta $(\mathrm{P}=0,0112)$ e cinza na carcaça $(\mathrm{P}=0,0150)$, enquanto o alelo $\mathrm{C}$ foi associado somente ao rendimento de fígado $(0,0102)$. No íntron 19 o SNP G915A foi genotipado por PCR-RFLP em 137 animais da população F2. O alelo A foi associado ao consumo de ração $(P=0,0339)$ ), o alelo $G$ ao rendimento de pulmão $(P=0,287)$ e os alelos $A$ e $G$ quando em homozigose foram associados com rendimento de coxas e sobrecoxas $(0,0302)$. Por ocorrerem em região de íntron, provavelmente esses SNPs não estão envolvidos diretamente com as características associadas, mas podem estar ligados a outra mutação localizada na região regulatória do gene do receptor da leptina ou em outro gene próximo. No futuro outros polimorfismos deverão ser explorados, em regiões codificadoras desse gene, para serem utilizados como marcadores associados a características de desempenho e carcaça em aves. Em adição o gene do receptor da leptina foi localizado no mapa de ligação do cromossomo 8 da população de aves da Embrapa, o próximo passo será realizar a análise de QTL incluindo os SNPs estudados como marcadores.
\end{abstract}

Palavras chave: Genes Candidatos, polimorfismos, gene da leptina, gene do receptor da leptina, Gallus gallus 


\begin{abstract}
Polymorphism identification in the leptin and leptin receptor gene in two chicken lines and its association with performance and carcass traits
\end{abstract}

The trend of industry in producing healthier nourishment, with less fat has raised sensibly. The challenge of animal breeding in the current days is to improve carcass quality of chickens with concomitant reduction in the fat content, witch is a consumer's demand. Leptin is a polypeptide hormone secreted mainly by adipocytes with an important role in the regulation of food ingestion, energy metabolism energy and reproduction. The leptin (LEP) and its receptor (LEPR) genes are being subject of intense investigation representing excellent candidate genes for fat deposition in the carcass in marker assisted selection programs. The function of those genes has been intensely studied in mammals, however, in birds few studies were accomplished. The present work aimed to investigate the occurrence of polymorphisms in the LEP and LEPR genes in Chickens, and also evaluate the effects of those polymorphisms on performance and carcass traits. Two chicken lines, a broiler (TT) and a layer line (CC) were used to develop an F2 reference population used in the present study. The reference population was developed in the Poultry Genetic Breeding System at Embrapa Suínos e Aves, in Concórdia/SC. Primers were designed for the PCR amplification of the LEP gene leptina and introns 8 and 19 of the LEPR gene. However, after several attempts it was not possible to amplify the genomic DNA or cDNA of the leptin gene. In the intron 8 of the LEPR gene, SNP C352T was genotyped by DNA sequencing of 247 animals of the $\mathrm{F} 2$ population. The $\mathrm{T}$ allele was associated with greater carcass yield $(\mathrm{P}=0,0165)$, breast yield $(\mathrm{P}=0,0137)$, grams of crude protein $(\mathrm{P}=0,0112)$ and ashes in the carcass $(\mathrm{P}=0,0150)$, while the $\mathrm{C}$ allele was associated only to liver yield $(0,0102)$. The SNP G915A in the intron 19 was genotyped by PCR-RFLP of 137 animals from the F2 population, the allele $A$ was associated to the feed intake $(P=0,0339)$, the allele $G$ to the lung yield $(P=0,287)$, and the alleles $A$ and $G$, when in homozigose, were associated with drumstick and thigh yield $(0,0302)$. Because these SNP are located within an intron area, they are not likely directly involved with the associated characteristics, but they can be linked the other mutation located in the regulatory area of the LEPR gene. In the future other polymorphisms should be explored, in the coding regions of this gene, so they can be used as markers associated to performance and carcass characteristics in poultry. In addition, the LEPR gene was located in the ligation map of the chromosome 8 for the Embrapa population. The next step will be to accomplish the analysis of QTL including the SNPs studied as markers.

Key words: Candidate genes, polymorphisms, leptin gene, leptina receptor, Gallus gallus 


\section{INTRODUÇÃO}

Nos últimos anos a avicultura tem ocupado lugar de destaque na agropecuária brasileira e internacional. De acordo com a Associação Brasileira de Exportadores de Frangos (2006), a produção mundial de carne de frango registrou em 2005 um aumento de 4,3\%, passando de 55,8 para 58,2 milhões de toneladas, sendo que a produção brasileira ficou acima dessa média, ao atingir 9,297 milhões de toneladas, 9,5\% acima do ano anterior. Essa produção manteve o País como o terceiro maior produtor, atrás apenas dos EUA e da China, onde a produção cresceu 3\% e $2 \%$, respectivamente.

Em 2005, o agronegócio avícola se consolidou como o segundo maior no ranking da exportação do agronegócio brasileiro, sendo que na classificação geral ocupa o sexto lugar, com uma participação de 2,6 \%. De acordo com o relatório da União Brasileira de Avicultura (UBA), as exportações brasileiras de carne de frango somaram 2,845 milhões de toneladas, com crescimento de $15 \%$ em relação a 2004, firmando o Brasil como o maior exportador mundial de carne de frango tanto em receita cambial quanto em volume de exportações. Esse desempenho foi influenciado positivamente pela ocorrência de problemas sanitários nos principais concorrentes do Brasil no mercado internacional de carnes. De acordo com UBA (2006), o Brasil trabalha com a manutenção e a consolidação dessa liderança nas exportações, estabelecendo metas como a abertura de novos mercados e a ampliação das exportações para os países que já são compradores de nosso produto.

Por ser grande produtor de grãos e pelos avanços tecnológicos alcançados, tanto na área genética como na industrial, o Brasil ganha importância cada vez maior, seja na produção de frangos, no consumo ou nas exportações. A indústria e os produtores brasileiros têm recebido relevantes contribuições dos programas de melhoramento genético. Entretanto, para que as indústrias brasileiras mantenham o nível de competitividade no mercado, será imprescindível a incorporação de novas técnicas moleculares como ferramentas nos programas tradicionais de melhoramento genético para que maiores progressos sejam obtidos.

A Biotecnologia, por meio da identificação de genes associados com características de interesse econômico, principalmente aquelas de difícil mensuração ou de baixa herdabilidade, têm permitido avanços nos programas de melhoramento, através de uma seleção mais efetiva. As 
diversas técnicas de biotecnologia têm contribuído para o desenvolvimento de mapas genéticos saturados e a identificação de locos controladores de características quantitativas (QTLs).

No caso do melhoramento animal, uma estratégia para a identificação de genes que controlem características de interesse é feita através de estudos utilizando-se genes candidatos cujas mutações possam ser associadas a uma determinada característica. Genes candidatos são genes de seqüência e ação biológica conhecida e que estão envolvidos com o desenvolvimento ou a fisiologia de uma determinada característica de interesse (BRYNE; MCMULLEN, 1996). De acordo com Rothschild e Soller (1999), o estudo de genes candidatos não tem alto custo e apresenta vantagens como: alto poder estatístico, ampla aplicabilidade, simplicidade operacional e conveniente aplicação à seleção assistida por marcadores (MAS - Marker Assisted Selection).

Nos últimos anos, o gene da leptina vem sendo objeto de intensa investigação representando um excelente gene candidato aos programas de seleção assistida por marcadores. Este gene foi caracterizado e identificado no tecido adiposo de camundongos mutantes obesos e estéreis (ob/ob) (ZHANG et al., 1994) os quais não produzem leptina devido a uma mutação genética. A leptina é um hormônio produzido principalmente no tecido adiposo e é considerado um fator de adiposidade presente no sangue, cuja síntese ocorre proporcionalmente à energia estocada na forma de gordura (FREDERICH et al., 1995). Quando as reservas de gordura corporal aumentam, a leptina atua no hipotálamo promovendo a redução do apetite e aumento dos gastos de energia (CARO et al., 1996).

A função do gene da leptina e de seu receptor tem sido intensamente estudada em mamíferos, porém, em aves ainda é pouco conhecida. A região codificadora da leptina foi identificada e caracterizada em galinhas (TAOUIS et al., 1998), sendo sua seqüência 83 \%, 96 \% e 97 \% idêntica aos homólogos em humanos, ratos e camundongos, respectivamente. Entretanto, Friedman-Einat et al. (1999) não conseguiram repetir os resultados usando os mesmos primers publicados por Taouis et al. (1998). Pitel et al. (2000) concluíram que o gene da leptina ainda não foi mapeado em galinhas, ao contrário do que foi publicado pelos mesmos autores anteriormente (PITEL et al., 1999).

Se por um lado ainda existem controvérsias a respeito do gene da leptina em galinhas, por outro lado o gene de seu receptor já está bem cararcterizado. Duun et al. (2000) mapearam o gene do receptor da leptina em galinhas no cromossomo 8. Em aves, esse gene é expresso no hipotálamo, ovário, intestino, fígado, rim (OHKUBO et al., 2000) e recentemente foi 
identificado nas células $\beta$-pancreáticas, sugerindo um papel importante deste gene na regulação da secreção da insulina (BENOMAR et al., 2003).

Considerando a importância em relação ao crescimento corporal, regulação da deposição de gordura e função endócrina, o presente trabalho teve como objetivo investigar a ocorrência de polimorfismos no gene da leptina e de seu receptor e sua associação com características de desempenho e carcaça numa população de aves desenvolvida pela Embrapa Suínos e Aves, Concórdia, SC. 


\section{REVISÃO BIBLIOGRÁFICA}

\subsection{Genética na avicultura}

Durante os últimos 80 anos, a seleção de linhagens de aves proporcionou inúmeros benefícios, dentre eles o aumento da produção de carne e ovos foi o que mais se destacou. No entanto, associado a esse sucesso da seleção fenotípica surgiram características indesejáveis, como o aumento de deposição de gordura na carcaça, maior incidência de doenças metabólicas, redução da fertilidade e da resistência a doenças infecciosas e aumento da incidência de osteoporose. Segundo Burt (2002), o progresso na produção de carne e ovos alcançará o seu limite nos próximos 30 anos, sendo assim, a prioridade da indústria avícola é reduzir perdas e desenvolver novos produtos.

O primeiro genoma seqüenciado em aves foi obtido a partir de uma fêmea da raça Red Jungle Fowl (Gallus gallus), espécie da qual descendem todas as raças e linhagens de galinhas domésticas, trabalho realizado pelo Consórcio Internacional de Seqüenciamento do Genoma da Galinha (HILLIER et al., 2004). De acordo com esses autores, o genoma da galinha servirá de modelo para outras 9.600 espécies de aves, além de conduzir a novas evidências para a compreensão do genoma humano e contribuir para a criação de galinhas mais saudáveis.

A galinha possui um genoma relativamente pequeno compreendendo $1,2 \times 10^{9}$ pares de base (pb), o que equivale a um terço do genoma humano, contendo um baixo número de DNA repetitivo, somente $11 \%$ quando comparado aos $40 \%$ a $50 \%$ encontrado em mamíferos, o que facilita o seqüenciamento e a procura por genes (HILLIER et al., 2004). O genoma da galinha é composto por 38 pares de autossomos e um par de cromossomos sexuais ( $\mathrm{Z}$ e $\mathrm{W}$ ): cinco são macrocromossomos, cinco são intermediários e 28 são microcromossomos. Diferente dos mamíferos, nas aves a fêmea é o sexo heterogamético (ZW) e o macho o sexo homogamético (ZZ). Os microcromossomos da galinha têm uma taxa de recombinação de 6,4 cM/Mb enquanto que os macrocromosomos de 2,8 cM/Mb, contrastando com 1-2 cM/Mb para a maioria dos cromossomos humanos. Essa alta taxa de recombinação faz da galinha um organismo ideal para estudos de ligação gênica, porém, mapas genéticos de alta resolução serão necessários para definir a taxa de recombinação dentro dos cromossomos (SCHIMD et al., 2005).

Atualmente há uma grande preocupação no mundo inteiro com a saúde e qualidade de vida da população, aumentando o cuidado com os alimentos que são consumidos. Em resposta 
a esta exigência por parte dos consumidores, a indústria avícola deverá produzir alimentos mais saudáveis. Para isto é necessário reduzir a deposição de gordura, bem como o uso de antibióticos e aumentar a resistência genética a patógenos. É difícil a solução destes problemas usando somente a seleção genética convencional, porém o seqüenciamento do genoma da galinha traz novas perspectivas para a moderna produção animal (BURT, 2006).

\subsection{Genes candidatos}

A genética molecular aplicada ao melhoramento animal tem como objetivo principal tornar as estratégias convencionais de seleção mais eficientes, promovendo maiores progressos genéticos em curto prazo. Algumas das diferenças genéticas entre os indivíduos são devidas a mutações em um único gene. No entanto, a maioria das características de importância econômica, como aquelas relacionadas a crescimento, fertilidade e resistência a doenças, é influenciada por diversos genes, cada um contribuindo com um pequeno efeito (BURT; HOCKING, 2002). Nesse contexto, o desenvolvimento de técnicas moleculares tem permitido o avanço na elucidação de como e quais genes influenciam características quantitativas de interesse econômico.

Nos últimos anos, a análise do genoma animal, através da clonagem e seqüenciamento, possibilitou a identificação de marcadores moleculares e de polimorfismos de DNA que podem ser utilizados como marcadores genéticos na seleção assistida (LEDUR, 2001). Um grande esforço da pesquisa em genômica de aves tem sido o mapeamento e identificação de locos que influenciam características quantitativas ou QTLs. Sua detecção pode ser feita por meio do uso de marcadores moleculares distribuídos ao longo do genoma, ou seja, uma varredura de todo o genoma (PLASTOW, 2000) ou de cromossomos específicos (ROTHSCHILD et al., 1995), buscando regiões do genoma que se segregam junto com a característica de interesse, ou ainda pela análise de genes candidatos (ROTHSCHILD; SOLLER, 1999; LI et al., 2003).

Os genes candidatos para uma determinada característica são genes já seqüenciados e de ação biológica conhecida e que estão envolvidos com características do desenvolvimento ou da fisiologia. Estes genes podem ser estruturais ou de uma via bioquímica regulatória que afeta a expressão da característica (BRYNE; MCMULLEN, 1996). O processo de identificação de QTL por meio de genes candidatos baseia-se na detecção de polimorfismos que possam estar associados a características fenotípicas de interesse, através de uma análise 
estatística apropriada, empregando-se dados provenientes de uma amostra da população. A probabilidade de que o polimorfismo do gene candidato investigado em uma população referência possa corresponder a um dos QTLs segregantes nessa população é consideravelmente grande como observada por Rothschild e Soller (1997).

Dentre as vantagens do uso de genes candidatos para mapeamento de QTL, podem ser destacados: o maior poder estatístico obtido com menor número de famílias e indivíduos quando comparado com análises de mapas de ligação; a ampla aplicabilidade, pois não é necessário utilizar-se populações com duas ou três gerações; o baixo custo após a determinação dos primers e detecção dos polimorfismos e a simplicidade operacional, pois se pode trabalhar com um único gene e não com o genoma inteiro. Finalmente, uma vez validado, o gene candidato pode ter utilização imediata na seleção assistida por marcadores Rothschild e Soller (1999).

As limitações desse procedimento são o pequeno número de genes conhecidos que controlam características de interesse, o efeito pleiotrópico de outros genes sobre o gene candidato, o alto custo da etapa inicial e a dificuldade no estabelecimento do efeito do gene candidato. Até que se estabeleça a variante causal do gene responsável pelo efeito quantitativo, sempre haverá a possibilidade de que o gene estudado não seja o gene que realmente esteja causando a diferença na característica, mas esteja somente ligado ao QTL. Isso pode levar a resultados contraditórios, dependendo da população estudada, pois associações significativas em uma população podem não ser verificadas em outras devido a quebra de ligação durante as recombinações (ROTHSCHILD; SOLLER, 1999).

O poder estatístico do teste de associação é maior quando regiões polimórficas usadas para genotipar o gene candidato estão em completo desequilíbrio de ligação, causando variação na função do gene, isto é, na sua região funcional (ROTHSCHILD; SOLLER, 1999). Sendo assim as análises de genes candidatos em uma população referência, proveniente do cruzamento entre duas linhagens divergentes, irá gerar desequilíbrio de ligação envolvendo grandes blocos de cromossomos contendo centenas de genes, o que permitirá a análise das regiões polimórficas e sua associação às características fenotípicas (ROTHSCHILD; SOLLER, 1999).

A identificação de marcadores moleculares associados a características fenotípicas de interesse permite a seleção assistida por marcadores genéticos em adição à seleção fenotípica e também auxilia a introgressão de determinada característica de uma população para outra, mantendo as características desejáveis da população receptora. Tal seleção mostra-se mais efetiva 
se aplicada em características de baixa herdabilidade, limitadas pelo sexo, como por exemplo, a produção de ovos, e características que não podem ser medidas diretamente ou de alto custo, como resistência a doenças, qualidade de carcaça e bem-estar animal (MUIR, 1999). Segundo Plastow (2000), o uso de marcadores de DNA para auxiliar na seleção visando à melhoria na qualidade da carne é uma das melhores oportunidades para a indústria avícola.

Alguns exemplos de aplicações de marcadores moleculares bem sucedidos, a partir de estudos de genes candidatos, têm sido descritos em espécies domésticas. Em suínos, Fujii et al. (1991) identificaram polimorfismos no gene do receptor da rianodina relacionados com a incidência de carne PSE (Pale, Soft and Exudative; pálida, flácida e com perda de água), e desenvolveram um método eficaz de identificar a presença da mutação ao amplificar a região em que a mutação ocorre e digerir o produto amplificado com enzima de restrição específica. Esse método é rotineiramente usado nos programas de seleção. Também em suínos, um polimorfismo no gene do receptor de estrogênio (ESR) tem mostrado um aumento no tamanho da leitegada (SHORT et al., 1995). Em raças bovinas, deleções no gene da miostatina são responsáveis pelo fenótipo de musculatura dupla nas raças Belgian Blue e Piamontese (GROBET et al., 1997).

Em aves, genes candidatos para algumas mutações já foram identificados ou sugeridos por estudos genéticos ou fisiológicos, tais como associação de polimorfismos do receptor da vitamina D (VDR) com o conteúdo mineral ósseo, do fator de crescimento semelhante à insulina-I (IGF-I) com peso corporal e da insulina (INS) com o peso corporal (BENNETT et al., 2006). Polimorfismos no gene do hormônio do crescimento (GH) foram associados ao peso corporal, tamanho da coxa e ganho de peso (NIE et al., 2005). Wang et al. (2006) associaram polimorfismos no gene da proteína de ligação de ácidos graxos (A-FABP), cujo papel está relacionado com ligação e transporte intracelular de ácidos graxos, com o peso e porcentagem de gordura abdominal.

No Brasil, a Embrapa Suínos e Aves e a ESALQ/USP iniciaram estudos na área de genômica de aves, com o objetivo de mapear QTLs e identificar genes candidatos para várias características de importância econômica. Para esse estudo foi desenvolvida uma população F2 específica para estudos de mapeamento do genoma da galinha, que vêm sendo utilizada para identificar marcadores associados a características de crescimento, consumo, eficiência alimentar, composição e rendimento de carcaça (LEDUR; BERTANI, 2002). Resultados obtidos por este grupo em estudos de mapeamento de QTLs nos cromossomos 1, 2, 3, 4 e 5 identificaram 4 regiões 
nos cromossomos 1, 3 e 4 associadas ao peso vivo aos 35, 41 e 42 dias de idade (BARON, et al. 2003, NONES, et al. 2003 e RUY, et al. 2003). Adicionalmente, resultados referentes ao cromossomo 1 (NONES et al., 2006) revelaram QTLs para peso corporal, consumo de alimento, peso de coxa e sobre coxa, peso de gordura abdominal, já identificados em outras populações, e QTLs para peso de moela, fígado, pulmões, coração e pés, e comprimento de intestino, ainda não descritos na literatura. A partir desses resultados pode-se, futuramente, investigar a relação dos QTL com genes candidatos. Neste mesmo grupo, Souza et al. (2005) associaram um polimorfismo no gene da miogenina com as características de peso vivo aos 42 dias de idade, ganho de peso do nascimento aos 42 dias de idade, ganho de peso dos 35 aos 42 dias de idade, peso da carcaça, peso das asas e da carcaça residual, peso da gordura abdominal, peso do fígado e do pulmão. Embora o polimorfismo esteja localizado em uma região codificadora, não implicou em qualquer alteração na seqüência de aminoácidos. Este resultado sugere que, possivelmente, este polimorfismo deve estar atuando como um marcador genético próximo ao verdadeiro sítio polimórfico responsável pelas variações fenotípicas observadas.

\subsection{Marcadores SNPs}

$\mathrm{Na}$ última década, houve um aumento significativo de tecnologias na área biológica, principalmente no que se refere aos progressos na área de seqüenciamento genômico. À medida que a seqüência nucleotídica dos genomas foi sendo desvendada, foi constatado um grande número de variações genéticas individuais. As variações que ocorrem com maior freqüência são denominadas polimorfismos de nucleotídeos únicos ou SNPs (Single Nucleotide Polymorphisms) e correspondem a posições onde existe uma única substituição de base na seqüência (GUIMARÃES; COSTA, 2002). Para que tal posição seja considerada como um SNP, assume-se que o alelo menos freqüente tenha uma abundância acima de 1\%. A princípio, os SNPs podem ser polimorfismos bi-, tri-, ou tetralélicos, entretanto na prática são em geral bialélicos (BROOKES, 1999), ocorrem com maior freqüência em todos os genomas, e provavelmente são responsáveis pela maioria das contribuições do genótipo na variação do fenótipo (BOTSTEIN; RISCH, 2003).

As substituições mais freqüentes que ocorrem no DNA são as que envolvem trocas entre duas purinas (A/G ou G/A) ou duas pirimidinas (C/T ou T/C) e são denominadas transições. As transversões são substituições de uma purina por uma pirimidina ou vice-versa. Essas 
alterações, algumas vezes, têm origem em erros de incorporação de bases durante a replicação do DNA. Alguns autores consideram inserções e deleções de pares de base como SNPs, embora certamente ocorram por um mecanismo diferente (VIGNAL et al., 2002).

Os SNPs ocorrem tanto em regiões codificadoras (exons) como em não codificadoras (íntrons) dos genomas. Em regiões codificadoras, quando resultam em uma substituição de aminoácido na seqüência protéica, são denominados não sinônimos, podendo a substituição ser conservativa ou não conservativa em função das características dos aminoácidos envolvidos na troca. Nesses casos, pode haver modificações estruturais e funcionais na proteína. Embora SNPs sinônimos não alterem a seqüência protéica, eles podem modificar a estrutura e a estabilidade do RNA mensageiro e, conseqüentemente afetar a quantidade de proteína produzida (KIM et al., 2003). As mutações que ocorrem nos íntrons não podem afetar diretamente a estrutura da proteína, entretanto, elas podem impedir a produção do RNA mensageiro, por exemplo, inibindo a união por splicing dos éxons (LEWIN, 2001).

Grande parte dos estudos tem relatado a associação entre um único SNP e uma determinada patologia, ou mesmo definido um SNP como um marcador para pré-disposição a uma determinada doença. Entretanto, visando a compreensão das bases moleculares de doenças de características genéticas mais complexas, pesquisas têm sido intensificadas no sentido de tentar associar, ao fenótipo alterado, conjuntos de determinados SNPs, denominados haplótipos (BROOKES, 2002).

Para identificar um SNP é necessário comparar a seqüência de diversos indivíduos. Quando dois alelos estão presentes no mesmo loco de um indivíduo fica difícil saber se é artefato de sequenciamento ou um sítio heterozigoto (VIGNAL et al., 2002).

O estudo de SNPs envolve duas fases: a identificação do SNP e a genotipagem. Para a genotipagem, podem ser utilizadas diversas metodologias, as quais são escolhidas de acordo com sua precisão, agilidade e custo. Métodos robustos de genotipagem podem ser citados: chips de DNA ou microarranjos, cromatografia líquida de alta pressão desnaturante (DHPLC), espectrometria de massa, PCR em tempo real e seqüenciamento de uma única base. Entretanto, em análises de menor escala, métodos como seqüenciamento e digestão por enzimas de restrição (RFLP) são rotineiramente empregados (VIGNAL et al., 2002).

Através do estudo de seqüências polimórficas em galinhas, significantes progressos têm sido feitos no entendimento das divergências fenotípicas entre indivíduos/raças e da evolução 
da população. Um estudo de polimorfismos foi realizado por Wong et al. (2004), utilizando a raça Red Jungle fowl e outras três linhagens de aves domésticas (machos de uma linhagem de corte, fêmeas de uma linhagem de postura e fêmeas da raça Silkie). Foram encontradas 3,1 milhões de variações na seqüência de DNA, 2,8 milhões caracterizadas com SNPs e 0,3 milhões como deleções. Mais de $90 \%$ desses SNPs são verdadeiros e em torno de $70 \%$ são SNPs comuns e segregam em diversas raças de galinhas. Além disso, os autores consideraram como SNPs todos os tipos de variações (substituição, deleção ou inserção), ocorrendo aproximadamente na freqüência de $5 \mathrm{SNPs} / \mathrm{Kb}$. Os polimorfismos ocorreram independentemente do tamanho do cromossomo, entretanto, esse resultado não era esperado, tendo em vista que a taxa de recombinação é mais alta nos microcromossomos do que nos macrocromossomos. Por outro lado, em outros organismos como humanos e Drosophila melanogaster, a taxa de recombinação correlaciona-se à ocorrência de polimorfismos (WONG et al., 2004).

No processo de identificação de SNPs, é necessário o uso de ferramentas da bioinformática. Com o desenvolvimento tecnológico de programas e de equipamentos cada vez mais robustos e sofisticados, vem sendo possível gerar e analisar um grande número de dados de seqüências de DNA (WANG et al., 2005). As ferramentas da bioinformática são utilizadas em várias etapas do estudo de polimorfismos, desde a identificação das variações até a predição do efeito das mesmas. Além disso, esses recursos também são úteis na construção e manutenção de bancos de dados que podem ser acessados pela Internet e que atuam como sedes de referência para a deposição de SNPs (GUIMARÃES; COSTA, 2002). O maior banco de dados público de polimorfismos é mantido pelo National Center for Biotechnology Information (NCBI), o dbSNP (http://www.ncbi.nlm.nih.gov/SNP), este banco recebe seqüências de mais de cem mil espécies do mundo inteiro.

\subsection{Caracterização do gene da leptina e de seu receptor}

De acordo com a teoria lipostática, descrita por Kennedy (1953), a regulação do balanço energético é intermediada por um produto do metabolismo energético presente na circulação sangüínea e que interage com receptores associados ao sistema nervoso central. Este modelo propõe que quando as reservas energéticas do tecido adiposo estão elevadas, os centros da saciedade no hipotálamo são ativados, provocando a redução da ingestão de alimentos e que 
durante a restrição alimentar ou jejum prolongado, ocorre a mobilização das reservas de gordura para a produção de energia com um aumento de apetite.

Hervey (1959) conduziu experimentos de parabiose, onde os sistemas circulatórios de ratos obesos e magros foram cirurgicamente unidos. Por este método, há troca de $1 \%$ de fluxo sangüíneo entre os camundongos. A partir desses resultados concluiu-se que o aumento da massa gordurosa produziu um fator circulante, o qual, em contato com o camundongo magro, atuou induzindo a saciedade. As primeiras evidências da existência de um fator circulante diretamente associado ao controle do consumo alimentar foram descritas nos experimentos de parabiose, conduzidos em camundongos geneticamente obesos (COLEMAN, 1973). Camundongos obesos $(o b)$ e diabéticos $(d b)$ apresentam uma mutação recessiva, resultando em obesidade e diabetes assemelhando-se a obesidade mórbida em humanos. Em experimento de parabiose envolvendo esses dois camundongos revelou-se que, enquanto o camundongo $d b / d b$ não era afetado o camundongo $o b / o b$ morreu por hipofagia. Sugerindo-se que os dois camundongos apresentavam mutações em genes distintos resultando em fenótipos similares e que o camundongo $d b / d b$ produz um fator circulante que regula o consumo de alimento em camundongos ob/ob. Assim, o camundongo ob/ob reage a um sinal de saciedade o qual é não é efetivo nos camundongos $d b / d b$.

Com os recursos da biotecnologia, (ZHANG et al., 1994) caracterizaram este fator circulante e seu gene foi clonado em ratos e humanos. Esse gene codifica um hormônio chamado leptina, o qual é 84 \% idêntico entre humanos e camundongos, representado por um RNA mensageiro de 4,5 Kilobases (Kb) com uma seqüência aberta de leitura (ORF) correspondente a 167 aminoácidos. A estrutura cristalina da proteína leptina mostra semelhança com inúmeras citocinas. Uma mutação, $(\mathrm{C} \rightarrow \mathrm{T})$ na posição 105 , nos camundongos $o b / o b$ resulta na mudança de uma arginina para um códon de finalização, formando uma proteína inacabada que não é liberada na corrente sanguínea. A administração exógena de leptina em camundongos ob/ob reparou as funções reprodutivas e endócrinas, assim como a redução do consumo de alimento e perda de peso (CHEHAB et al. 1996).

Os níveis plasmáticos de leptina estão altamente correlacionados à massa de tecido adiposo e diminuem acentuadamente tanto em humanos quanto em camundongos após a perda de peso (MAFFEI et al., 1995). A proteína leptina está presente no soro de roedores normais, tendo sua concentração aumentada com a obesidade (FREDERICH et al., 1995). O rim é o maior sítio de catabolismo da leptina, removendo 80\% de toda leptina do plasma humano (MEYER et al., 
1997), entretanto, os níveis plasmáticos dessa proteína permanecem constantes, sugerindo-se que a leptina é secretada continuamente a partir dos adipócitos (CUMIN et al., 1996), sendo a sua velocidade de remoção igual à taxa de produção (VILÀ et al., 1998). Em mamíferos, a leptina é sintetizada principalmente no tecido adiposo, embora análises de RT-PCR tenham demonstrado a expressão de mRNA da leptina na placenta (MASUZAKI et al., 1997), no estômago (BADO et al., 1998) e no cérebro (MORASH et al., 1999) de roedores e humanos.

A proteína leptina é sintetizada no tecido adiposo e secretada na corrente sanguínea agindo no sistema neural regulando o consumo de alimento, metabolismo de glicose, metabolismo de gordura, gasto de energia, puberdade e fertilidade de mamíferos (FRIEDMAN; HALLAS, 1998). A leptina produzida e secretada pelas células do tecido adiposo é transportada via corrente sanguínea, para tecidos alvos, onde interage com receptores celulares específicos. O receptor da leptina pertence à classe I da família de receptores de citocina, a qual também pertencem os receptores do hormônio do crescimento, da prolactina e da interleucina-6, entre outros.

A ação da leptina é feita a partir da ativação de seus receptores na membrana citoplasmática. O gene do receptor da leptina foi clonado primeiramente em mamíferos e classificado como membro da família de receptor de citocina tipo I (TARTAGLIA et al. 1995). São descritas seis isofomas do receptor da leptina, cinco apresentam forma curta com domínio intracelular pequeno e um apresenta forma longa. A comparação entre as isoformas revela que o domínio extracelular é comum, mas a porção do domínio citoplasmático é variável. Porém somente a forma longa contém um domínio intracelular que é capaz de transmitir o sinal de ligação com a leptina para dentro da célula, através do sistema Janus Kinase (JAK)/Sinal de ativação e tradução da transcrição (STAT) de transdução do sinal após sua ligação com a leptina (LICINIO et al., 1998).

Estudos sobre os mecanismos de ação da leptina, realizados com seres humanos e com linhagens de camundongos obesos $(o b / o b)$ ou diabéticos $(d b / d b)$, demostraram o envolvimento da leptina no controle do apetite e na modulação da secreção de insulina pelo pâncreas. A leptina, por meio de uma ação autócrina, inibe a captação de glicose estimulada pela insulina, reduz a lipogênese e estimula a lipólise no tecido adiposo. Numa ação endócrina, a leptina estimula a captação da glicose e a síntese de glicogênio pelas células do tecido muscular, além de acelerar a taxa de oxidação de ácidos graxos neste tecido (CEDDIA et al., 1998). A ação da leptina no sistema nervoso central (hipotálamo), em mamíferos, promove a redução da ingestão 
alimentar e o aumento do gasto energético, além de regular a função neuroendócrina e o metabolismo da glicose e de gorduras. A leptina é sintetizada também na glândula mamária, músculo esquelético, epitélio gástrico e na placenta (FRIEDMAN-EINAT et al., 1999).

A associação de polimorfismos com características de interesse econômico tais como crescimento corporal e deposição de gordura são de grande relevância para os programas de melhoramento genético. Em suínos, Robert et al. (1998) observaram que polimorfismos no gene da leptina estavam asssociados com animais magros e que níveis elevados de mRNA da leptina estavam correlacionados com maior espessura de gordura subcutânea. Em estudos conduzidos por Buchanan et al. (2002), em bovinos de corte, polimorfismos no exon 2 do gene da leptina foram associados à deposição de gordura na carcaça, esses polimorfismos foram caracterizados pela transição de uma citosina (C) para uma timina (T) que codifica a mudança de um aminoácido arginina para uma cisteína. A freqüência do alelo T foi associada com carcaças mais gordas, com maior expressão gênica da leptina e com as raças Angus e Hereford. Por outro lado, a freqüência do alelo C foi associada com carcaças mais magras, com menor nível de expressão do gene da leptina e com as raças Charolês e Simental.

\subsection{Gene da leptina e seu receptor em aves}

A função do gene da leptina tem sido intensamente estudada em mamíferos, porém, em aves ainda é pouco conhecida. Sua região codificadora foi identificada e caracterizada em galinhas por Taouis et al. (1998), sendo sua seqüência 83\%, 96\% e 97\% idêntica aos homólogos em humanos, ratos e camundongos, respectivamente. A leptina em galinhas contém o aminoácido arginina na posição 105 e apresenta dois resíduos de cisteína nas posições 113 e 165, essenciais ao processo de enovelamento durante a síntese desse peptídeo. Embora, tenha sido identificada uma cisteína adicional na posição 21 exclusivamente na leptina de aves, sua função biológica ainda permanece desconhecida nestes animais.

Ao contrário dos mamíferos, em aves o gene da leptina é expresso principalmente no fígado e tecido adiposo. A expressão hepática da leptina foi detectada exclusivamente em galinhas por Taouis et al. (1998), esta particularidade pode ser atribuída ao metabolismo lipídico das aves, onde o fígado é o órgão primário da lipogênese. Dridi et al. (2005), estudaram a expressão do gene da leptina e níveis de circulação deste hormônio em duas linhagens de aves, uma selecionada para alta deposição de gordura e outra para baixa deposição de gordura. Em 
adição, os efeitos de leptina de galinha recombinante no metabolismo do fígado foram investigados. A expressão da leptina hepática e níveis de leptina no plasma foram altamente significativos na linhagem selecionada para alta deposição de gordura ao contrário da linhagem de baixa deposição de gordura e a administração da leptina recombinante baixou a expressão do gene do receptor da leptina no fígado.

Entretanto, permanecem controvérsias sobre o gene da leptina em galinhas. Friedman-Einat et al. (1999), na tentativa de confirmar os resultados obtidos por Taouis et al. (1998), desenharam 14 pares de primers, sendo que quatro eram idênticos às seqüências publicadas anteriormente. Os experimentos conduzidos por Friedman-Einat et al. (1999) foram realizados em laboratórios pertencentes a diferentes instituições de pesquisa, porém não houve amplificação. Os testes foram realizados com cDNA do tecido hepático, pancreático e adiposo de camundongo, frango de corte, peru, ganso, codorna e bantam (galinha de pequeno porte), porém, somente em camundongos foi obtido o fragmento esperado.

Pitel et al. (1999) mapearam o gene da leptina da galinha no cromossomo 7, porém esses mesmos autores numa publicação posterior (PITEL et al., 2000) sequenciaram o produto de PCR gerado pelos primers construídos a partir da seqüência descrita por Taouis et al. (1998), contudo as seqüências obtidas não apresentaram similaridade com a seqüência publicada nem com a de qualquer outra seqüência do genoma da galinha disponível no GenBank.

Recentemente, Carre et al. (2006) não encontraram o gene da leptina entre 578,445 ESTs de frango analisadas. Além disso, não foi possível amplificar o gene da leptina com base nos primers publicados por Taouis et al. (1998).

Em Israel, o grupo de pesquisa liderado pela Dra. Miriam Friedman-Einat está em uma fase avançada de clonagem do gene da leptina e já foi dado início aos procedimentos de patenteamento. De acordo com Friedman-Einat (http://www.agri.gov.il/Units/Kidum/einat.html), os resultados dessa pesquisa serão publicados somente após a conclusão do processo de patenteamento.

Em galinhas, o cDNA do receptor da leptina é composto por 1148 aminoácidos, e sua seqüência é 62\%, 61\% e 59\% idêntica ao receptor da leptina em humanos, bovinos e roedores, respectivamente (HOREV et al., 2000). Através de análise de segregação, Dunn et al. (2000) localizaram o gene do receptor da leptina no cromossomo 8 da galinha. A seqüência do gene do receptor da leptina de perus também foi caracterizada, com 94\% de identidade com a seqüência de 
galinhas (RICHARDS et al., 2003). Em aves, a expressão desse gene descrita no hipotálamo, ovário, intestino, fígado e rim (OHKUBO et al., 2000) e, por último, foi identificada nas células $\beta$-pancreáticas, sugerindo-se um papel importante desse gene na regulação da secreção da insulina (BENOMAR et al., 2003).

Ao investigar polimorfismos no gene do receptor da leptina em duas linhagens divergentes para peso corporal, Kuo et al. (2002) encontraram uma mutação no nucleotídeo 182 (C-T) no íntron 8. A linhagem leve apresentou formas homozigotas (T-T) e heterozigotas (C-T) e a linhagem pesada apenas a forma homozigota (C-C). A identificação de polimorfismos nesse gene poderá contribuir para o melhor entendimento dos mecanismos moleculares envolvidos na regulação da composição e crescimento corporal em aves. Gu et al. (2002), investigaram o gene do receptor da leptina em várias linhagens de Gallus gallus, encontrando uma mutação silenciosa localizada no exon 9. Dois SNPs identificados no íntron 8 do gene do receptor da leptina foram associados a deposição de gordura abdominal e peso do fígado em linhagens de frangos de corte selecionadas divergentemente para gordura abdominal (WANG et al., 2004). Levando-se em consideração, a grande extensão do gene do receptor da leptina, que compreende 20 exons, juntamente com a possível ocorrência de splicing alternativo, pode-se sugerir que esses e outros polimorfismos precisam ser investigados. 


\section{MATERIAL E MÉTODOS}

\subsection{População experimental}

Duas linhagens de aves, uma de corte (TT) e uma de postura (CC) foram utilizadas para desenvolver a população referência F2 empregada no presente estudo. Tanto as linhagens (TT e CC) como a população F2 foram desenvolvidas no sistema de Melhoramento Genético de Aves da Embrapa Suínos e Aves, em Concórdia/SC. As linhagens empregadas no cruzamento, TT e CC, apresentam composições genéticas distintas, pois a linhagem de corte teve sua origem a partir do cruzamento das raças Cornish, Hamshire e White Plymouth Rock, enquanto a linhagem de postura foi originada da raça White Leghorn.

A linhagem TT é uma linha paterna de corte, cuja seleção foi efetuada dentro de linha com o objetivo de melhorar o peso corporal, conversão alimentar, rendimentos de carcaça e partes, viabilidade, fertilidade, eclodibilidade, redução da gordura abdominal e de doenças metabólicas. Na época da formação da população referência, a linhagem TT havia sido selecionada para estas características por seis gerações. A linhagem CC foi selecionada por oito gerações, para melhorar a produção de ovos, peso do ovo, conversão alimentar, viabilidade, maturidade sexual, fertilidade, eclodibilidade, qualidade do ovo e um reduzido peso corporal. Maiores informaçoes sobre as linhagens TT e CC podem ser obtidas em (FIGUEIREDO et al., 2003 a,b)

Para a formaçao da população F2, sete machos TT e sete fêmeas CC foram escolhidos ao acaso e utilizados como parentais no cruzamento, na proporção de um macho TT para uma fêmea CC. As aves foram mantidas em gaiolas individuais, com controle de pedigree e os ovos foram identificados para possibilitar o anelamento, ao nascer, dos pintos da primeira geração, chamada F1 TC. A geração F1 consta de sete famílias obtidas do cruzamento de machos de corte com fêmeas de postura. Em cada família foram escolhidos ao acaso três machos e seis fêmeas F1. Estas aves foram criadas como matrizes de frango de corte e alojadas em gaiolas individuais.

Para a formação da segunda geração, chamada F2, foram selecionados um macho e três fêmeas, ao acaso, de cada uma das sete famílias da população F1. Cada macho fecundou três fêmeas, por meio de inseminação artificial, evitando-se acasalamentos entre parentes. Um total de sete machos e 21 fêmeas F1 geraram cerca de 100 pintos F2 por família de F1 em 17 incubações, com intervalos de 15 dias durante quase oito meses, totalizando cerca de 2060 aves F2, sendo que metade dessas aves era macho e a outra metade fêmea. 
As aves da população F2 foram aneladas, com controle de pedigree individual, sendo criadas como frangos de corte recebendo ração e água a vontade. Essas aves tiveram suas características de desempenho e carcaça avaliadas. Os animais receberam ração inicial de 1 a 21 dias de idade (21\% de proteína bruta, PB e 3.150 kcal de energia metabolizável, EM), ração de crescimento de 22 a 35 dias de idade (20\% de PB e 3.200 kcal de EM) e ração final de 36 a 41 dias de idade (18,5\% de PB e 3.200 kcal de EM). As rações formuladas foram à base de milho e farelo de soja para atender as necessidades nutricionais das aves. Nas Tabelas 1 e 2 são apresentadas a estrutura populacional e as relações de parentesco nas famílias que deram origem a população F2 TCTC, respectivamente.

Tabela 1 - Estrutura da população referência F2 TCTC

\begin{tabular}{lccc}
\hline Geração & Machos & Fêmeas & Total \\
\hline Parental & 7 & 7 & 14 \\
F1 & 7 & $20^{1}$ & 27 \\
F2 & 1039 & 1024 & 2063 \\
\hline
\end{tabular}

${ }^{1}$ Houve perda por morte de uma fêmea F1.

Tabela 2 - Relações de parentesco nas famílias que deram origem à população F2 TCTC

\begin{tabular}{|c|c|c|c|c|c|c|c|}
\hline \multicolumn{8}{|c|}{ Casais Parentais: } \\
\hline macho TT & $\underline{5649}$ & $\underline{5661}$ & $\underline{5561}$ & $\underline{6232}$ & $\underline{5921}$ & $\underline{6037}$ & $\underline{5596}$ \\
\hline $\begin{array}{c}\text { fêmea CC } \\
\left(n^{\circ} \text { casal) }\right.\end{array}$ & $\begin{array}{l}886 \\
(1)\end{array}$ & $\begin{array}{l}88 \\
(2)\end{array}$ & $\begin{array}{l}570 \\
(3)\end{array}$ & $\begin{array}{c}332 \\
(4)\end{array}$ & $\begin{array}{l}37 \\
(5)\end{array}$ & $\begin{array}{l}241 \\
(6)\end{array}$ & $\begin{array}{l}05 \\
(7)\end{array}$ \\
\hline \multicolumn{8}{|c|}{ Casais F1: } \\
\hline macho TC & 7716 (1) & $7769(2)$ & $7797(3)$ & $7822(4)$ & $7975(5)$ & $7977(6)$ & $7985(7)$ \\
\hline fêmeas TC & 7761 (7) & $7749(6)$ & 7972 (5) & $7765(2)$ & $7713(3)$ & $7722(1)$ & 7805 (1) \\
\hline (n ${ }^{\circ}$ casal & $7810(4)$ & $7816(4)$ & 7812 (4) & $7971(5)$ & $7980(7)$ & $7771(2)$ & $7736(4)$ \\
\hline parental) & $7978(6)$ & 7709 (3) & 7992 (2) & 7798 (3) & $7755(6)$ & 7987 (7) & $7743(5)$ \\
\hline
\end{tabular}

Os números apresentados para machos e fêmeas são equivalentes aos anéis das aves. 


\subsection{Coleta de dados fenotípicos e de amostras de sangue}

As características fenotípicas avaliadas para o desempenho foram: peso ao nascer (PN), aos 35 (P35), 41 (P41) e 42 (P42) dias de idade. O peso aos 42 dias foi medido após 6 horas de jejum e transporte para o abate, que foi realizado no abatedouro do Campo Experimental de Suruvi, pertencente a Embrapa Suínos e Aves. Foram avaliadas também as características: ganho de peso (GP), consumo de ração (CR) e eficiência alimentar (EA) dos 35 aos 41 dias de idade.

Após o abate, as carcaças foram evisceradas e os pesos de coração (COR), fígado (FIG), pulmão (PUL), moela (MO) e comprimento de intestino (CI) foram avaliados. Após 4 horas de resfriamento, foi avaliado o peso da carcaça (sem cabeça, pés, vísceras e penas - CARC) e o peso das partes: cabeça (CABE), peito (com pele e ossos - PEIT), asas (ASA), dorso (DORSO), coxas (peso de coxas e sobre coxas - COXA), pés (PES) e gordura abdominal (GA). Também foram realizados cálculos para rendimento dos órgãos: rendimento de coração (RCOR), de fígado (RFIG), de pulmão (RPUL) e de moela (RMO), e rendimento da carcaça e de suas partes: rendimento de carcaça (RCARC), de peito (RPEIT), de asas (RASA), de dorso (RDORSO), de coxas e sobre coxas (RCOXA), de pés (RPES) e rendimento de gordura abdominal (RGA). Os valores de rendimento foram obtidos dividindo-se o peso da característica pelo peso vivo aos 42 dias e multiplicando-se por 100.

Após a avaliação de peso, as carcaças foram identificadas, colocadas em sacos plásticos e armazenadas em câmara fria a $-7{ }^{\circ} \mathrm{C}$. Posteriormente, as carcaças foram moídas para a realização das análises de composição da carcaça no Laboratório de Análises Físico-Químico da Embrapa Suínos e Aves. Os teores de proteína, gordura, água e cinza nas carcaças foram determinados utilizando Espectroscopia de Infravermelho Próxima (NIR). O equipamento NIR System 6500 (Silver Spring, MD, USA) foi primeiramente calibrado utilizando 100 aves de diferentes cruzamentos.

Klein et al. (2002) apresentam os resultados de validação da utilização do NIR para a determinação da composição da carcaça. Estes autores concluem que o NIR pode ser utilizado para essas análises com a mesma exatidão dos métodos convencionais de laboratório, com a vantagem de serem mais rápidas e não gerarem resíduos tóxicos. As características de composição de carcaça avaliadas foram: matéria seca (MS), umidade (UM), gramas de proteína bruta (PB), proteína bruta na matéria natural (PB_MN), proteína bruta na matéria seca (PB_MS), gramas de cinza (CZ), cinza na matéria natural (CZ_MN), cinza na matéria seca (CZ_MS), 
gramas de extrato etéreo (EE), extrato etéreo na matéria natural (EE_MN) e extrato etéreo na matéria seca (EE_MS).

Todos os dados fenotípicos obtidos estão armazenados em um Banco do Setor de Melhoramento de Aves da Embrapa, para realização de diversos estudos envolvendo genes candidatos e mapeamento de QTLs.Foram coletados $10 \mathrm{~mL}$ de sangue da veia braquial, sem anticoagulante, para posterior análise de colesterol (COL) e triglicerídeos (TRIGLI) no soro. Até o momento da análise essas amostras foram armazenadas em freezer $-20^{\circ} \mathrm{C}$. Para extração de DNA, amostras de sangue foram coletadas em tubos contendo EDTA 10\% e armazenadas em freezer a $-70^{\circ} \mathrm{C}$. Alíquotas de sangue foram levadas para o Laboratório de Biotecnologia Animal (ESALQ/USP- Piracicaba, SP) e o restante está sendo mantido como um Banco de Sangue na Embrapa Suínos e Aves para futuros estudos.

\subsection{Análise de colesterol e triglicerídeos}

O soro das aves foi submetido à análise de colesterol total e triglicerídeos, utilizando-se kits comerciais (Labtest Diagnóstica SA). O protocolo usado para a determinação de colesterol total e triglicerídeos foi o mesmo, porém, utilizando-se kits com composições diferentes. Para determinação de colesterol foi utilizado um kit composto de: tampão 50 mmol, pH 7,0 (fenol 24,0 mmol/L, colato de sódio $500 \mu \mathrm{mol} / \mathrm{L}$, azida sódica 15 mmol/L, 4 aminoantipirina $500 \mu \mathrm{mol} / \mathrm{L}$, colesterol esterase $\geq 250 \mathrm{U} / \mathrm{L}$, colesterol oxidase $\geq 250 \mathrm{U} / \mathrm{L}$ e peroxidase $\geq 1000$ U/L.) e um padrão $200 \mathrm{mg} / \mathrm{dL}$ (colesterol $200 \mathrm{mg}$ e azida sódica $15 \mathrm{mmol} / \mathrm{L}$ ). Para determinação de triglicerídeos foi utilizado um kit composto de: tampão $50 \mathrm{mmol} / \mathrm{L}, \mathrm{pH}$ 6,9 (acetato de magnésio 4 mmol/L; 4-clorofenol 5 mmol/L; 4-aminoantipirina $300 \mu \mathrm{mol} / \mathrm{L}$ ATP 1,0 mmol/L; lipase da lipoproteína $\geq 1400 \mathrm{U} / \mathrm{L}$; glicerolquinase $\geq 1000 \mathrm{U} / \mathrm{L}$ e azida sódica 7 mmol/L) e um padrão 200 mg/dL (triglicérides 200 mg/dL e ázida sódica 7 mmol/L).

As determinações do colesterol total e triglicerídeos foram realizadas por espectrofotometria. O espectrofotômetro foi primeiramente calibrado, adicionando-se $1000 \mu \mathrm{L}$ do tampão (Kit) em um tubo de ensaio e em outro tubo adicionou-se $1000 \mu \mathrm{L}$ do tampão a $10 \mu \mathrm{L}$ do padrão (Kit). Para a análise, adicionou-se $1000 \mu \mathrm{L}$ de tampão a $10 \mu \mathrm{L}$ de soro de cada amostra. Os reagentes de cada tubo foram misturados e em seguida mantidos em banho-maria a $37{ }^{\circ} \mathrm{C}$ durante dez minutos. A absorbância das amostras foi determinada por espectrofotometria a $500 \mathrm{~nm}$. O valor da absorbância foi obtido, dividindo-se o valor da absorbância do teste pela absorbância do 
padrão multiplicando-se por 200 (valor da concentração do padrão). Todas as amostras foram analisadas em duplicata, e os resultados referem-se à média de duas determinações. Os mesmos procedimentos foram realizados para a determinação dos triglicerídeos.

\subsection{Extração e quantificação de DNA}

Foram utilizadas duas metodologias de extração de DNA, com o objetivo de se obter DNA íntegro e em concentração suficiente para as análises de polimorfismos. Para a extração de DNA genômico dos animais parentais e F1, utilizou-se o protocolo de extração de DNA com Proteinase K e para os animais F2 o reagente DNAzol (Invitrogen).

Para a extração de DNA com Proteinase K, $1 \mathrm{~mL}$ de tampão de lise de células vermelhas (0,32 $\mathrm{M}$ de sucrose, $12 \mathrm{mM}$ Tris- $\mathrm{HCl} \mathrm{pH}$ 7,5, $5 \mathrm{mM} \mathrm{MgCl}_{2}, 1 \%$ Triton $\left.\mathrm{X}\right)$ foi adicionado em $50 \mu \mathrm{L}$ de sangue conservado em EDTA, seguindo-se centrifugação por um minuto a 1400 x g e descarte do sobrenadante. A adição do tampão de lise seguida da centrifugação e descarte do sobrenadante foi realizada duas vezes, para obter-se um sobrenadante límpido. Foram adicionados $500 \mu \mathrm{L}$ de água, seguindo-se de centrifugação a 1400 x g por um minuto e descarte do sobrenadante. Em seguida o pellet foi ressuspendido em $80 \mu \mathrm{L}$ do tampão de proteinase $\mathrm{K}$ (0,37 M NaCl, 0,12 M EDTA pH 8,0), $7 \mu \mathrm{L}$ de proteinase $\mathrm{K}(20 \mathrm{mg} / \mathrm{mL}), 10 \mu \mathrm{L}$ de SDS 20\% e $283 \mu \mathrm{L}$ de água destilada, seguindo-se de incubação a $55{ }^{\circ} \mathrm{C}$ por uma hora. Após a incubação, foram adicionados $120 \mu \mathrm{L}$ de $\mathrm{NaCl} 5 \mathrm{M}$ seguindo-se de homogeneização (vórtex) por 15 segundos e centrifugação a 1400 x g por cinco minutos. O sobrenadante foi transferido para um novo tubo, sendo adicionado $1 \mathrm{~mL}$ de etanol absoluto seguindo-se de centrifugação por cinco minutos a 1400 $\mathrm{x} g$ e descarte do sobrenadante. Foi feita uma segunda lavagem, utilizando-se etanol $95 \%$, seguindo-se de centrifugação a $1400 \mathrm{x}$ g por cinco minutos e descarte do sobrenadante. O pellet foi desidratado à temperatura ambiente por uma hora e em seguida ressuspendido em $100 \mu \mathrm{L}$ de água Milli-Q estéril e armazenado a $-20{ }^{\circ} \mathrm{C}$.

Para a extração de DNA com o reagente DNAzol (Invitrogen), $500 \mu \mathrm{L}$ de DNAzol foram adicionados a $5 \mu \mathrm{L}$ de sangue conservado em EDTA, seguindo-se de homogeneização (vórtex). Após a homogeneização foram adicionados $250 \mu \mathrm{L}$ de etanol absoluto, invertendo-se cuidadosamente cada amostra. O DNA precipitado foi coletado com o auxílio de um micropipetador e transferido para um novo tubo. A seguir, foram feitas duas lavagens com $500 \mu \mathrm{L}$ de etanol 95 \%, seguindo-se de centrifugação a 1000 x $g$ por dez minutos entre as lavagens. Na 
última lavagem, o sobrenadante foi descartado e o pellet desidratado à temperatura ambiente por 30 minutos e em seguida ressuspendido em $100 \mu \mathrm{L}$ de água Milli- $Q$ estéril e armazenado a $-20{ }^{\circ} \mathrm{C}$.

O DNA foi quantificado em espectrofotômetro (HITACHI, modelo U-200) em 260 nm. Após a quantificação, as amostras foram diluídas para a concentração de $20 \mathrm{ng} / \mu \mathrm{L}$ e submetidas à eletroforese em gel de agarose $1 \%$ para a verificação da integridade do DNA e confirmação da concentração.

\subsection{Desenho dos primers}

Os primers para a amplificação das regiões de interesse foram desenhados com base nas seqüências do gene da leptina (Lep) e do receptor da leptina (Rlep) disponíveis no GenBank (www.ncbi.nlm.nih.gov), com a utilização do programa Primer3 (http://wwwgenome.wi.mit.edu/cgi-bin/primer/primer3_www.cgi). A qualidade dos primers foi verificada com o auxílio do programa Net Primer (http://www.premierbiosoft.com/netprimer/netprlaunch /netprlaunch.html). O par de primers Lep_4 foi descrito por Dridi et al. (2005). O número de acesso ao GenBank, localização, seqüência dos primers e o tamanho do fragmento amplificado podem ser observados na Tabela 3.

Tabela 3 - Seqüência dos primers desenhados e tamanho da região flanqueada

\begin{tabular}{|c|c|c|c|c|c|}
\hline Primer & Gene & $\begin{array}{c}\text { Acesso } \\
\text { GenBank }\end{array}$ & Localização & Seqüência dos primers & $\begin{array}{c}\text { Tamanho } \\
\text { pb }\end{array}$ \\
\hline RL_1 & Rlep & AF222783 & Intron 8 & $\begin{array}{l}\text { Direto: 5’-TCTGGAGTGAATGGAGCACA -3' } \\
\text { Reverso: 5’-GCTACGCTCTGGGTTTTGTT -3 }\end{array}$ & 754 \\
\hline RL_2 & Rlep & AY348717 & Intron 19 & $\begin{array}{l}\text { Direto: 5’-AAAACCAGCACCCTGAAATG-3' } \\
\text { Reverso: 5’-CAGACTGTGCTTGGGGATTT-3' }\end{array}$ & 940 \\
\hline Lep_1 & Lep & AF012727 & $*$ & $\begin{array}{l}\text { Direto: 5’-CCAAAACCCTCATCAAGACC - 3' } \\
\text { Reverso:5’-TGAAGCCCAGGAATGAAGTC- 3' }\end{array}$ & 1856 \\
\hline Lep_2 & Lep & AF012727 & $*$ & $\begin{array}{l}\text { Direto:5'-CACCAGGATCAATGACATTTCAC-3' } \\
\text { Reverso:5’-ACCTCTGTGGAGTAGAGTGAGGC-3' }\end{array}$ & 2012 \\
\hline Lep_3 & Lep & AF012727 & $*$ & $\begin{array}{l}\text { Direto: 5’-GACTTCATTCCTGGGCTTCA- 3' } \\
\text { Reverso: 5’-CTCAAAGCCACCACСTCTGT- 3' }\end{array}$ & 272 \\
\hline Lep_4 ${ }^{1}$ & Lep & AF012727 & $*$ & $\begin{array}{l}\text { Direto: 5’-ACACGTCGGTATCCGCCAAG- 3' } \\
\text { Reverso: 5'-AGCAGATGGAGGAGGTCTCG- 3' }\end{array}$ & 190 \\
\hline
\end{tabular}

${ }^{1}$ Primer descrito por Dridi et al. (2005).

* Localização dos primers não determinada, pois a seqüência do gene da leptina de Gallus gallus não está disponível no Genbank. 


\subsection{Gene da Leptina}

\subsubsection{Otimização das condições de amplificação por PCR}

Para o gene da leptina foram encontradas dificuldades de amplificação. Em decorrência dessas dificuldades, foram desenhados quatro pares de primers e diferentes metodologias foram utilizadas para a otimização da reação usando os primers Lep_1, Lep_2, Lep_3 e Lep_4. Foi utilizado o PCR Optimizer Kit (Invitrogen), constituído por tampões com diferentes concentrações de magnésio e pH, sendo que todos os tampões têm em comum $300 \mathrm{mM}$ de Tris-HCl e 75 mM de Sulfato de amônio. Para cada reação foram utilizados $3 \mu \mathrm{L}$ de DNA genômico (20 ng/ $\mu \mathrm{L}$ ) adicionados a $22 \mu \mathrm{L}$ do mix de reação composto pelos seguintes reagentes: 5,0 $\mu \mathrm{L}$ de um dos tampões $5 \mathrm{X}$ (A, B, C, E e J), $1 \mu \mathrm{L}$ de dNTP $(10 \mathrm{mM}), 2,5 \mu \mathrm{L}$ de cada primer (2,5 pmoles/ $\mu \mathrm{L}$ ), 0,3 $\mu \mathrm{L}(1 \mathrm{U})$ de enzima Taq DNA polimerase (Invitrogen), para um volume final de $25 \mu \mathrm{L}$. Os quatro pares de primers selecionados para o gene da leptina foram testados com os tampões A, B, C, E e J (Tabela 4).

Tabela 4 - Composição dos tampões A, B, C, E e J

\begin{tabular}{cc}
\hline Tampão & Composição \\
\hline Tampão A 5X & $\mathrm{MgCl}_{2} 7,5 \mathrm{mM}, \mathrm{pH} 8,5$ \\
Tampão B 5X & $\mathrm{MgCl}_{2} 10 \mathrm{mM}, \mathrm{pH} 8,5$ \\
Tampão C 5X & $\mathrm{MgCl}_{2}$ 12,5 mM, pH 8,5 \\
Tampão E 5X & $\mathrm{MgCl}_{2} 7,5 \mathrm{mM}, \mathrm{pH} \mathrm{9,0}$ \\
Tampão J 5X & $\mathrm{MgCl}_{2} 10 \mathrm{mM}, \mathrm{pH} 9,5$ \\
\hline
\end{tabular}

Além dos testes com tampões com concentrações de magnésio e pH diferentes, foram feitos testes com diferentes condições de amplificação com o objetivo de se estabelecer uma condição ótima para cada um dos pares de primers. Na Tabela 5 são apresentados os programas usados para a otimização da PCR usando os primers Lep_1, Lep_2, Lep_3 e Lep_4. Os produtos da PCR foram aplicados em gel de agarose 1\% para confirmação do tamanho dos fragmentos amplificados. O marcador de peso molecular utilizado variou de acordo com o tamanho do fragmento esperado, foram utilizados os marcadores $1 \mathrm{~Kb}$ ladder (invitrogen) e $\phi \mathrm{x}$ 174 (invitrogen). 
Tabela 5 - Programas utilizados no termociclador na otimização da PCR usando os primers Lep_1, Lep_2, Lep_3 e Lep_4

\begin{tabular}{ccc}
\hline Passos & Temperatura & Tempo \\
\hline 1 & 92 a $95^{\circ} \mathrm{C}$ & 2 a 3 minutos \\
2 & 92 a $95^{\circ} \mathrm{C}$ & 1 minuto \\
3 & 45 a $70^{\circ} \mathrm{C}$ & 1 minuto \\
4 & $72{ }^{\circ} \mathrm{C}$ & 1 minuto \\
5 & Repetir os passos 2 ao $4(29$ vezes $)$ & \\
6 & $72^{\circ} \mathrm{C}$ & 10 minutos \\
7 & $4^{\circ} \mathrm{C}$ & Indefinidamente \\
\hline
\end{tabular}

\subsubsection{Extração e quantificação de RNA total}

Uma vez que não foi possível amplificar o gene da leptina usando DNA genômico, a alternativa foi tentar amplificar o cDNA. Para isso foi necessária a extração de RNA do tecido adiposo e hepático de frangos de corte com 21 dias de idade.

O isolamento do RNA total do tecido adiposo e hepático foi realizado segundo o protocolo descrito no reagente TRIZOL (Invitrogen). Os tecidos coletados foram macerados em 1 $\mathrm{mL}$ de TRIZOL e incubados por cinco minutos a temperatura ambiente. A esta mistura foram adicionados $200 \mu \mathrm{L}$ de clorofórmio, sendo incubados por cinco minutos a temperatura ambiente. Após centrifugação a 12000 x g por 15 minutos a $4{ }^{\circ} \mathrm{C}$, a fase aquosa foi recuperada em um tubo novo. A este foram adicionados $500 \mu \mathrm{L}$ de isopropanol seguindo-se de incubação por dez minutos a temperatura ambiente. Em seguida, foram centrifugadas a $10000 \mathrm{x}$ g por dez minutos a $4{ }^{\circ} \mathrm{C}$ e o pellet lavado com $1 \mathrm{~mL}$ de etanol 75\%, sendo procedida nova centrifugação a $10000 \mathrm{x}$ g por 15 minutos a $4^{\circ} \mathrm{C}$. O pellet foi desidratado a temperatura ambiente e ressuspendido em $20 \mu \mathrm{L}$ de água-DEPC para posterior determinação da concentração de RNA total por espectrofotômetro. As amostras foram submetidas à eletroforese em gel de agarose 1\% para verificação da integridade do RNA total. 


\subsubsection{Síntese de cDNA}

A síntese de cDNA foi feita empregando-se o Kit SuperScript First-Strand Synthesis System for RT-PCR (Invitrogen). Os cDNAs foram sintetizados a partir de $5 \mu$ g de RNA total das amostras de tecido, $1 \mu \mathrm{L}$ de primer oligo $(\mathrm{dT})-0,5 \mu \mathrm{g} / \mu \mathrm{L} ; 1 \mu \mathrm{L}$ de dNTP mix $10 \mathrm{mM}$; após incubação à $65{ }^{\circ} \mathrm{C}$ por cinco minutos, a reação foi resfriada em gelo por um minuto. Ao serem retiradas do gelo as amostras receberam $2 \mu \mathrm{L}$ de Buffer RT $10 \mathrm{X} ; 4 \mu \mathrm{L}$ de $\mathrm{MgCl}_{2} 25$ mM; $2 \mu \mathrm{L}$ de DTT 0,1 M e $1 \mu \mathrm{L}$ de RNase OUT (40 u/ $\mu \mathrm{L}$ ) em um volume final de $20 \mu \mathrm{L}$. A reação foi incubada a $42{ }^{\circ} \mathrm{C}$ por dois minutos e posteriormente foram adicionadas 50 unidades da enzima Superscript II RT (Invitrogen). A transcrição reversa foi feita a $42{ }^{\circ} \mathrm{C}$ por 50 minutos, procedendose a inativação da enzima a $70{ }^{\circ} \mathrm{C}$ durante 15 minutos. Para remover o RNA molde da molécula híbrida cDNA:RNA foi feita digestão com duas unidades de RNase $\mathrm{H}$ por 20 minutos a $37^{\circ} \mathrm{C}$.

\subsubsection{RT-PCR}

Para verificação da integridade do cDNA, primeiramente foi realizada a reação de PCR para o gene constitutivo beta-actina. Para a amplificação do cDNA da leptina o par de primers Lep_3 foi escolhido por localizar-se numa região codificadora. Foram feitos testes para a otimização das condições de amplificação com o objetivo de se estabelecer uma condição ótima.

Para cada reação foram utilizados $2 \mu \mathrm{L}$ de cDNA (20 ng/ $\mu \mathrm{L})$ adicionados a $23 \mu \mathrm{L}$ do mix de reação composto pelos seguintes reagentes: 1,0 $\mu \mathrm{L}$ de tampão $10 \mathrm{X}$ (50 mM de KCl, 10 mM Tris-HCl pH 9,0), $1 \mu \mathrm{L}$ de $\mathrm{MgSO}_{4}$ (50 mM), $1 \mu \mathrm{L}$ de dNTP (10 mM), 2,5 $\mu \mathrm{L}$ de cada primer (2,5 pmoles $/ \mu \mathrm{L}$ ), 0,25 $\mu \mathrm{L}$ (1U) de Taq DNA polimerase (Invitrogen), para um volume final de 25 $\mu \mathrm{L}$. Na Tabela 6 são apresentados os programas usados para a otimização da PCR. Os produtos da PCR foram visualizados em gel de agarose 1\% para confirmação do tamanho dos fragmentos amplificados utilizando-se o marcador de peso molecular $\phi x 174$ (Invitrogen). 
Tabela 6 - Programas utilizados para a otimização das reações por RT-PCR para o primer Lep_3

\begin{tabular}{lll}
\hline Etapas & Temperatura & Tempo \\
\hline Desnaturação inicial & $95^{\circ} \mathrm{C}$ & $1-5$ minutos \\
Desnaturação & $95^{\circ} \mathrm{C}$ & $1-2$ minutos \\
Anelamento & $45^{\circ} \mathrm{C}$ a $65^{\circ} \mathrm{C}$ & 1 minuto \\
Extensão & $72^{\circ} \mathrm{C}$ & $1-2$ minutos \\
Extensão final & $72^{\circ} \mathrm{C}$ & 10 minutos \\
$\mathrm{N}^{\text {o de ciclos }}$ & 30 & \\
\hline
\end{tabular}

\subsection{Gene do receptor da leptina}

\subsubsection{Otimização das condições e amplificação por PCR}

Foram realizados testes de otimização das condições de amplificação para os primers do gene do receptor da leptina (RL_1 e RL_2) com o objetivo de se estabelecer uma condição ótima para cada um dos pares de primers. Foi necessária somente a otimização da temperatura de melting (Tm) de cada primer, obtida com o programa Primer3, foi realizado um gradiente com uma variação de cinco graus acima e cinco graus abaixo da Tm indicada pelo programa para a realização da PCR.

Para a reação de PCR dos primers RL_1 e RL_2, foram utilizados $3 \mu \mathrm{L}$ de DNA genômico (20 ng/ $\mu \mathrm{L}$ ) adicionados a $22 \mu \mathrm{L}$ do mix de reação composto pelos seguintes reagentes: 2,5 $\mu \mathrm{L}$ de tampão 10 X (50 mM de KCl, 10 mM Tris-HCl pH 9,0 ), $1 \mu \mathrm{L}$ de $\mathrm{MgSO}_{4}(50 \mathrm{mM}), 1$ $\mu \mathrm{L}$ de dNTP (10mM), 2,5 $\mu \mathrm{L}$ de cada primer (2,5 pmoles/ $\mu \mathrm{L}), 0,1 \mu \mathrm{L}$ (1U) de enzima Platinum Taq DNA Polymerase High Fidelity (Invitrogen), para um volume final de $25 \mu \mathrm{L}$.

Para a amplificação dos fragmentos do gene do receptor da leptina (primers RL_1 e RL_2), foi feita uma desnaturação inicial por um minuto a $95{ }^{\circ} \mathrm{C}$, seguindo-se de uma nova desnaturação por um minuto a $95{ }^{\circ} \mathrm{C}$. As condições de anelamento foram de $60{ }^{\circ} \mathrm{C}$ para RL_1 e $62{ }^{\circ} \mathrm{C}$ RL_2 por um minuto e a extensão a $72{ }^{\circ} \mathrm{C}$ por um minuto seguindo-se de uma extensão final a $72{ }^{\circ} \mathrm{C}$ por dez minutos. Foram realizados 30 ciclos nas reações para os dois pares de primers. Os produtos da PCR foram visualizados em gel de agarose $1 \%$ para confirmação do tamanho dos fragmentos amplificados utilizando o marcador de peso molecular $\phi x 174$ 
(Invitrogen). O tamanho esperado dos produtos da PCR e a seqüência dos primers utilizados na amplificação de cada região do gene do receptor da leptina são apresentados na Tabela 3.

\subsubsection{Purificação dos produtos da PCR}

Após a amplificação foi feita a purificação dos produtos da PCR, que consiste na retirada de resíduos de primers e nucleotídeos não incorporados para obtenção de seqüências de melhor qualidade. Para esta finalidade procedeu-se o seguinte protocolo recomendado no GFX PCR DNA and Gel Band Purification Kit (GE Health Care): A coluna (Kit) foi encaixada no tubo coletor (Kit), sendo adicionados $500 \mu \mathrm{L}$ de Capture buffer e $20 \mu \mathrm{L}$ do produto de PCR. Após centrifugação por 1 minuto a 14400 x g o tubo coletor foi descartado e um novo tubo foi encaixado à coluna. Foram adicionados à coluna $500 \mu \mathrm{L}$ de Wash buffer $(10 \mathrm{mM}$ Tris-HCl pH 8,0, 1 mM EDTA) seguindo-se de centrifugação por um minuto a 14400 x g. O tubo coletor foi descartado e a coluna foi transferida para um tubo de $1,5 \mathrm{~mL}$ e a esse foram adicionados $30 \mu \mathrm{L}$ de água Milli-Q seguindo-se de incubação à temperatura ambiente por um minuto e centrifugação por um minuto a $14400 \mathrm{x}$ g. As amostras foram submetidas a eletroforese em gel de agarose $1 \%$ juntamente com o padrão de concentração pGEM4Z $(40 \mathrm{ng} / \mu \mathrm{L})$ para a verificação da concentração.

\subsubsection{Reação de Seqüenciamento}

A reação de seqüenciamento foi realizada segundo o protocolo do kit Big Dye Terminator Cycle Sequencing Ready Reaction (Applied Biosystems). Para cada reação de seqüenciamento foram utilizados: $2 \mu \mathrm{L}$ de Tampão Save Money (200 mM de Tris pH 9, 0,5 mM $\mathrm{MgCl}_{2}$ ), $1 \mu \mathrm{L}$ de primer (2,5 pmoles/ $\mu \mathrm{L}$ ), $2 \mu \mathrm{L}$ de Kit Big Dye e 50 ng de DNA. O programa utilizado para a reação de seqüenciamento compreendeu as seguintes etapas: desnaturação a $95^{\circ} \mathrm{C}$ por 20 segundos, anelamento a $60{ }^{\circ} \mathrm{C}$ por 15 segundos e extensão a $60^{\circ} \mathrm{C}$ por um minuto, totalizando 25 ciclos.

\subsubsection{Purificação da reação de seqüenciamento}

Para a purificação da reação de seqüenciamento foram adicionados $80 \mu \mathrm{L}$ de isopropanol 65\% a reação, seguindo-se de homogeneização (vórtex) e incubação no escuro por 15 minutos a temperatura ambiente. Após a centrifugação por 45 minutos a 3200 x g, o sobrenadante 
foi removido por inversão e foram adicionados $150 \mu \mathrm{L}$ de etanol $60 \%$ seguindo-se de centrifugação por 15 minutos, a 3200 x g a temperatura ambiente. O pellet foi desidratado por uma hora a temperatura ambiente e ressuspendido em $10 \mu \mathrm{L}$ de formamida. As amostras foram desnaturadas a $95^{\circ} \mathrm{C}$ por cinco minutos, resfriadas em gelo e aplicadas em seqüenciador automático ABI 3100 (Applied Biosystems).

\subsubsection{Análise das seqüências e escolha dos polimorfismos}

Para a detecção de polimorfismos, as seqüências de nucleotídeos da geração parental foram analisadas quanto à qualidade e alinhadas com o auxílio dos programas Phred/Phrap/Consed (Ewing \& Green, 1998; Gordon et al., 1998). Foram selecionadas as sequências com qualidade (Phred) superior ou igual a 20, valor estipulado como qualidade mínima. O mesmo processo foi realizado nos 20 animais da geração F1 para a confirmação dos polimorfismos encontrados.

Após confirmação, os polimorfismos considerados de maior interesse foram selecionados para a genotipagem da geração F2. O critério utilizado para a seleção desses polimorfismos foi a ocorrência dos mesmos em famílias F1 informativas (formadas por casais heterozigotos), bem como famílias F1 já estudadas pelo grupo de pesquisa do Laboratório de Biotecnologia Animal em parceria com a Embrapa Suínos e Aves. Adicionalmente, a identificação de sítios de restrição nas seqüências, realizada com o auxílio do programa Webcutter (http://www.firstmarket.com/firstmarket/cutter/), foi relevante para a seleção dos polimorfismos.

\subsection{Genotipagem}

Na região do primer RL_1 o loco estudado foi C352T, onde não foi encontrado nenhum sítio de restrição. Foram selecionadas quatro famílias informativas (7765, 7798, 7810 e 7798), totalizando 247 aves, para a genotipagem por seqüenciamento. Dessas quatro famílias, três já foram avaliadas nos estudos de QTL realizados pela parceria do Laboratório de Biotecnologia Animal com a Embrapa Suínos e Aves.

Para a região amplificada pelo primer RL_2, o loco estudado foi o G915A, sendo que a genotipagem foi realizada com a utilização da técnica de PCR-RFLP (Polymerase Chain Reaction-Restriction Fragment Length Polymorphism). Foram selecionadas duas famílias informativas (7713 e 7972), um total de 137 aves para esta região, as quais também foram 
avaliadas em estudos anteriores realizados no Laboratório de Biotecnologia Animal. Os produtos da PCR foram tratados com a enzima de restrição Bsp1407 I e incubados a $37{ }^{\circ} \mathrm{C}$ por três horas. O volume final da reação foi de $15 \mu \mathrm{L}$, constituindo-se de 1,0 $\mu \mathrm{L}$ de buffer Tango $10 \mathrm{X}(10 \mathrm{mM}$ KCl, 10m M Tris-HCl pH 7,4, 1 mM EDTA, 1 mM DTT, 0,2 mg/mL de BSA e 50\% de glicerol), 0,4 unidades de enzima Bsp1407I, $10 \mu \mathrm{L}$ de DNA amplificado, completando-se o volume com água Milli-Q. A seqüência das bases reconhecidas pela enzima de restrição Bsp1407I pode ser observada na Figura 1.

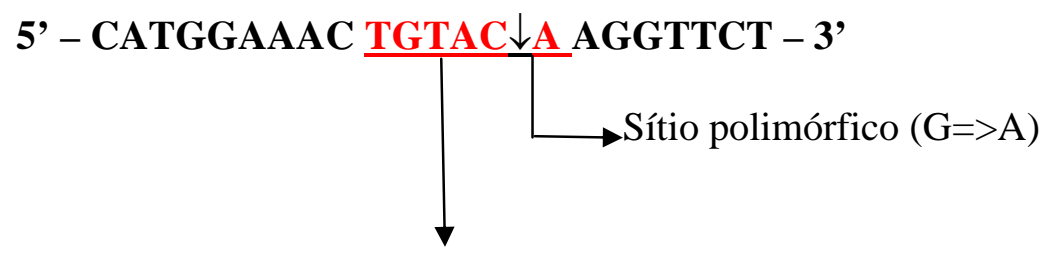

Seqüência reconhecida pela enzima Bsp1407I

Figura 1 - Sítio de restrição da enzima Bsp1407I, utilizada para a genotipagem do polimorfismo G915A encontrado no íntron 19 do gene do receptor da leptina

\subsection{Análise estatística}

A freqüência genotípica foi determinada usando o PROC FREQ do SAS (2002). Para cada SNP estudado, foi realizada primeiramente uma análise das freqüências dos genótipos nas diferentes famílias e nos sexos para verificar a possibilidade de inclusão ou não das interações genótipo x família e genótipo x sexo no modelo.

A associação dos SNPs identificados com as características de interesse econômico avaliadas foi realizado por análise de variância usando-se o procedimento GLM do SAS (2002). As características fenotípicas avaliadas foram: P35, P41, P42, GP, CR, EA, COR, FIG, PUL, MO, CI, CARC, CABE, PEIT, ASA, DORSO, COXA, PES, GA, MS, UM, PB, PB_MN, PB_MS, CZ, CZ_MN, CZ_MS, EE, EE_MN, EE_MS, COL, TRIGLI, RCOR, RFIG, RPUL, RMO, RCARC, RPEIT, RASA, RDORSO, RCOXA, RPES e RGA. 
Na análise da variância foram utilizados os efeitos fixos de incubação (I), família de mãe $(F)$, sexo $(S)$, genótipo $(G)$ e a interação de sexo com genótipo $(S \times G)$, em um modelo linear como segue:

$$
y_{i j k l m}=\mu+I_{i}+F_{j}+S_{k}+G_{l}+(S \times G)_{k l}+e_{i j k l m} \text { em que: }
$$

$Y_{i j k l m}=$ representa o valor fenotípico de cada característica; $\mu=$ média geral da característica; $I_{i}=$ efeito fixo da $\mathrm{i}^{\text {ésima }}$ incubação $(\mathrm{i}=1,2, \ldots, 17$ para o loco C352T e i=1,2,...,10 para o loco G915A); $F_{j}$ = efeito fixo da jésima família (j=1,2,3,4 para o loco C352T e j=1,2 para o loco G915A); $S_{k}=$ efeito fixo do $\mathrm{k}^{\text {ésimo }}$ sexo $(\mathrm{k}=1,2) ; G_{l}=$ efeito fixo do lésimo genótipo $(\mathrm{l}=1,2,3)$; $(S \times G)_{k l}=$ efeito fixo do kl ${ }^{\text {ésimo }}$ interação sexo e genótipo; $e_{i j k l m}=$ erro aleatório.

Os efeitos aditivos e de dominância foram estimados através de contrastes linear e quadrático, respectivamente. Os valores de probabilidade dos efeitos gerados na análise de variância foram classificados como altamente significativos (**) quando $\mathrm{P}<0,01$ e significativos (*) quando $\mathrm{P}<0,05$.

Foi realizada a análise exploratória de dados através da análise gráfica de resíduos e da observação de diagramas de ramos e folhas, no intuito de verificar possíveis dados discrepantes (“outliers”) e inconsistências nas suposições da análise da variância.

\subsection{Localização do gene do receptor da leptina no mapa de ligação da Embrapa}

No cromossomo 8, onde está localizado o gene do receptor da leptina de Gallus gallus, tem sido realizados estudados de QTLs na população da Embrapa por Moura et al. (2006). O gene do receptor da leptina foi localizado no mapa de ligação do cromossomo 8 da população da Embrapa com o objetivo de integrar resultados entre os estudos realizados nesta população.

Para a construção do mapa de ligação foram utilizados os marcadores MCW0095, ADL0154, ABR0345, ABR0322 e ADL0172, que são apresentados na Tabela 7, e o SNP C352T. Os marcadores microssatélites foram genotipados em quatro famílias de irmãos-completos (7765, 7971, 7810 e 7978) enquanto o SNP C352T foi genotipado apenas em três delas (7765, 7810 e 7978) Os marcadores MCW0095, ADL0154 e ABR0345 foram selecionados no mapa consenso publicado por Groenen et al. (2000) que utilizou informações provenientes de três populações referência diferentes, East Lansing, Compton e Wageningen. Os marcadores ABR0322 e 
ADL0172 foram selecionados no mapa da população East Lansing (MOURA et al. 2006). Os mapas consenso e da população de East Lansing estão disponíveis no site ArkDB (http://www.thearkdb.org/).

O mapa de ligação foi construído pelo método da máxima verossimilhança, com o auxílio do programa CRIMAP (GREEN et al., 1990), que utiliza a função de Kosambi para transformar fração de recombinação em distância de mapa em cM. As informações de pedigree e genótipos dos marcadores foram digitadas em arquivo de editor de texto com o formato requerido pelo programa. Os seguintes procedimentos foram empregados: a) twopoint, que gera valores de verossimilhança para as probabilidades de ligação de cada par de marcadores; b) build, que ordena todos os marcadores de acordo coma taxa de recombinação entre eles. O programa utiliza como default o LOD superior a 3, que implica que a hipótese dos marcadores estarem ligados é 1000 vezes mais provável que a de não estarem.

Tabela 7 - Marcadores microssatélites do cromossomo 8, indicando a posição e os mapas de ligação em que foram mapeados

\begin{tabular}{lccc}
\hline \multicolumn{1}{c}{ Marcador } & Cromossomo & Posição no mapa (cM) & Mapa \\
\hline ABR0322 & 8 & 5 & East Lansing \\
MCW0095 & 8 & 26 & Consenso 2000 \\
ADL0154 & 8 & 46 & Consenso 2000 \\
ABR0345 & 8 & 56 & Consenso 2000 \\
ADL0172 & 8 & 95 & East Lansing \\
\hline
\end{tabular}




\section{RESULTADOS E DISCUSSÃO}

\subsection{Extração de DNA}

As amostras de sangue dos animais parentais e F1 não se encontravam em bom estado de conservação, provavelmente pelo tempo de estocagem superior ao das amostras dos animais F2 e pelas várias vezes em que foram descongeladas. Para essas amostras o protocolo de extração de DNA com Proteinase K mostrou-se mais eficiente. Já para a extração de DNA das amostras dos animais F2, os quais o sangue apresentava-se em bom estado de conservação, foi utilizado o protocolo de extração com o reagente DNAzol (Invitrogen), sendo este um método que apresentou maior facilidade e rapidez de extração.

Após a extração, todas as amostras tiveram sua concentração determinada por espectrofotometria e ajustada para $20 \mathrm{ng} / \mathrm{uL}$. As amostras padronizadas foram aplicadas em gel de agarose 1\% para verificação da qualidade do DNA, conforme pode ser observado na Figura 2.

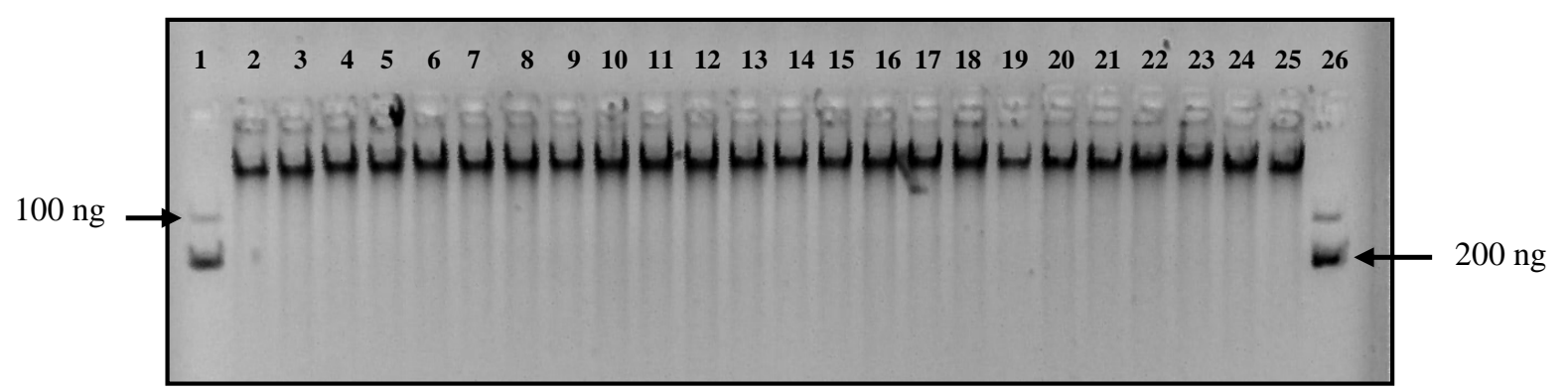

Figura 2 - Gel de agarose 1\% para visualização da qualidade do DNA. As amostras 1 e 26 correspondem ao padrão de peso molecular (plasmídeo pGEN4Z - 100 e 200 ng/uL). As amostras 2 a 25 correspondem ao DNA extraído

\subsection{Desenho dos primers}

Para este trabalho foi necessário o desenho de cinco pares de primers. O desenho de primers para PCR é um passo importante para uma reação bem sucedida. Apesar de ser um procedimento simples, é necessário respeitar algumas regras para garantir um anelamento correto entre os primers e a seqüência alvo. Para tanto algumas ferramentas de bioinformática que podem ser utilizadas. 
Os primers para a amplificação das regiões de interesse foram desenhados com base nas seqüências do gene da leptina (Lep) e de seu receptor (RLep) disponíveis no GenBank (www.ncbi.nlm.nih.gov). A seqüência completa do gene da leptina em galinhas ainda não está disponível em nenhum banco de dados, por isso, foram escolhidas as seqüências de cDNA de galinha (Gallus gallus - GenBank AF012727) e camundongo (Mus musculus - GenBank NM_008493), por apresentarem maior similaridade entre as seqüências disponíveis no GenBank. Após a escolha, estas seqüências foram alinhadas com a utilização do programa Multalin (CORPET, 1988 - http://prodes.toulouse.inra.fr/multalin/multalin.html). Na Figura 3 pode-se visualizar o alinhamento das seqüências. Com base no alinhamento, foram desenhados três pares de primers em regiões conservadas do gene nessas duas espécies. Baseando-se na seqüência do gene da leptina de camundongos descrita por He et al. (1995), supõe-se que na seqüência do gene da leptina de galinha estudada exista um íntron (íntron 2) com aproximadamente 1730 pb. Sendo assim, o primeiro par de primers (Lep_1) que amplifica uma região de 1856 pb e o segundo (Lep_2) que amplifica uma região de 2012 pb, foram desenhados numa região flanqueando o íntron 2. O terceiro par de primers (Lep_3) foi desenhado para amplificar uma região de 272 pb no exon 3, enquanto que o quarto (Lep_4) que amplifica uma região de 190 pb foi selecionado do trabalho descrito por Dridi et al. (2005). Na Figura 4, podem ser visualizadas as seqüências dos primers desenhados para o gene da leptina, bem como a região flanqueada pelos mesmos. 
ATGTGCTGGAGACCCCTGTGTCGACTTTGGTCATACCTTGTTTATGTTCAAGCAGTGCCGTGCCAGATCTTCCAGG Lep_1 Direto Lep_2 Direto Lep_4 Direto ATGACACCAAAACCCTCATCAAGACCATTGTCACCAGGATCAATGACATT...íntron_2...TCACACACGTCGGTAT Lep_1 Reverso e Lep_3 Direto CCGCCAAGCAGAGGGTCACTGGCTTGGACTTCATTCCTGGGCTTCACCCCATTCTGAGTTTGTCCAAGATGGACCA GACTCTGGCAGTCTATCAACAGGTCCTCACCAGCCTGCCTTCCCAAAATGTGCTGCAGATAGCCAATGACCTGGAG Lep_4 Reverso AATCTCCGAGACCTCCTCCATCTGCTGGCCTTCTCCAAGAGCTGCTCTCTGCCTCAGACCAGTGGCCTGCAGAAGC

Figura 4 - Seqüência de cDNA do gene da leptina de Gallus gallus (AF012027), localização dos primers e do provável íntron

Para o gene do receptor da leptina foi desenhado um par de primers (RL_1) localizados entre o final do exon 8 e o início do exon 9 (GenBank AF222783), flanqueando uma região intrônica de 754 pb (Figura 5). Para a segunda região do gene do receptor da leptina, o par de primers (RL_2) foi desenhado para amplificar parte do íntron 19 (GenBank AY348718S2), flanqueando $940 \mathrm{pb}$ (Figura 6).

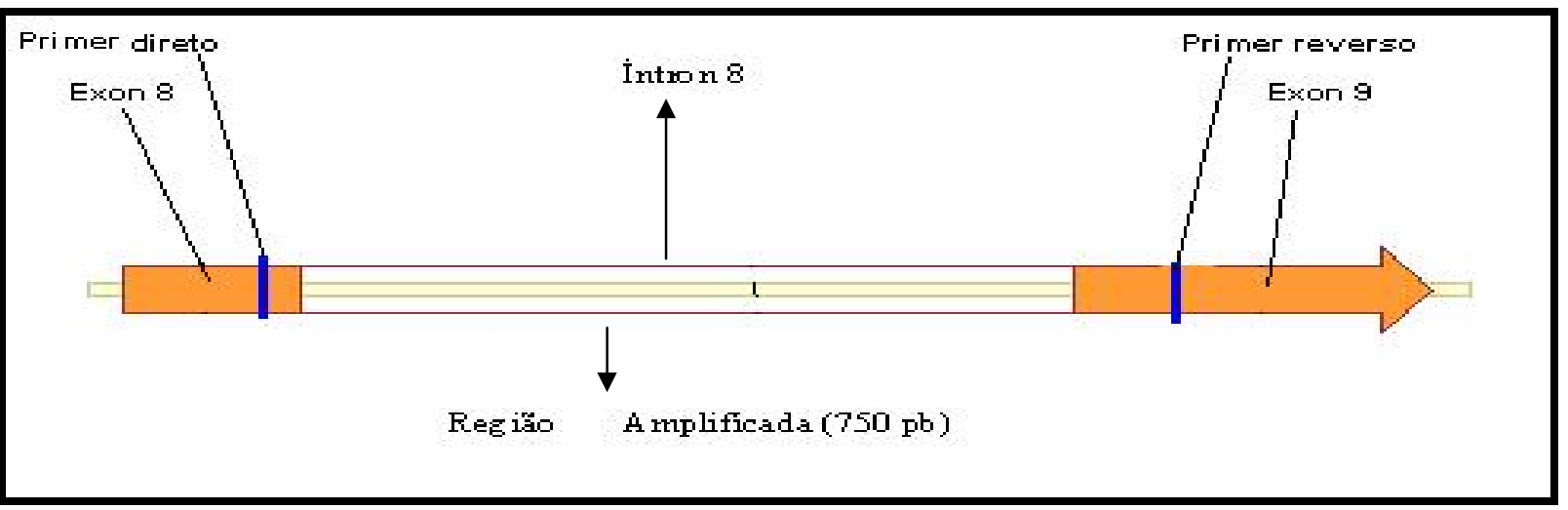

Figura 5 - Região do íntron 8 do gene do recepetor da leptina onde foi desenhado o par de primers RL_1 


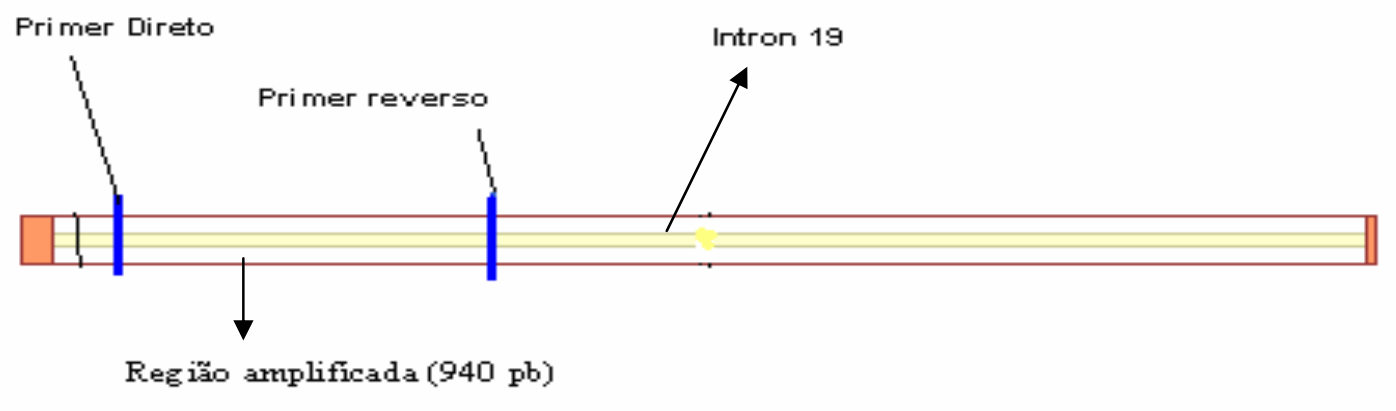

Figura 6 - Região do íntron 19 do gene do receptor da leptina onde foi desenhado o par de primers RL_2

\subsection{Indentificação de polimorfismos}

A detecção de polimorfismos envolve o conhecimento da seqüência de DNA para um mesmo loco de vários indivíduos dentro de uma determinada população, permitindo a observação de posições específicas que possam apresentar variações as quais caracterizem diferentes alelos. Para que isso seja possível, as seguintes etapas são necessárias: escolha do gene a ser estudado, desenho de primers específicos para a seqüência de interesse, seguindo-se da amplificação por PCR, sequenciamento, análise das seqüências e escolha do método de genotipagem. Neste trabalho, todas as etapas mencionadas foram seguidas.

\subsection{Gene da leptina}

\subsubsection{Otimização das condições e amplificação por PCR}

Para o gene da leptina, ao todo foram testados 4 pares de primers. Foram feitos vários testes para a otimização das condições de amplificação dos primers, utilizando-se os tampões A, B, C, E, e J (PCR Optimizer Kit - Invitrogen) contendo diferentes pHs e concentrações de $\mathrm{MgCl}_{2}$, submetidos a um gradiente de temperatura variando de $45{ }^{\circ} \mathrm{C}$ a $70{ }^{\circ} \mathrm{C}$. No entanto, nenhum dos quatro pares de primers testados gerou bandas específicas (Figuras 7, 8, 9 e 10). Os tamanhos esperados dos fragmentos eram 1856, 2012, 272 e 190 pb, respectivamente, para os primers Lep_1, Lep_2, Lep_3 e Lep_4. Os produtos amplificados foram visualizados em géis de agarose $1 \%$ para verificação do tamanho esperado dos produtos da PCR para cada um dos primers utilizados. 


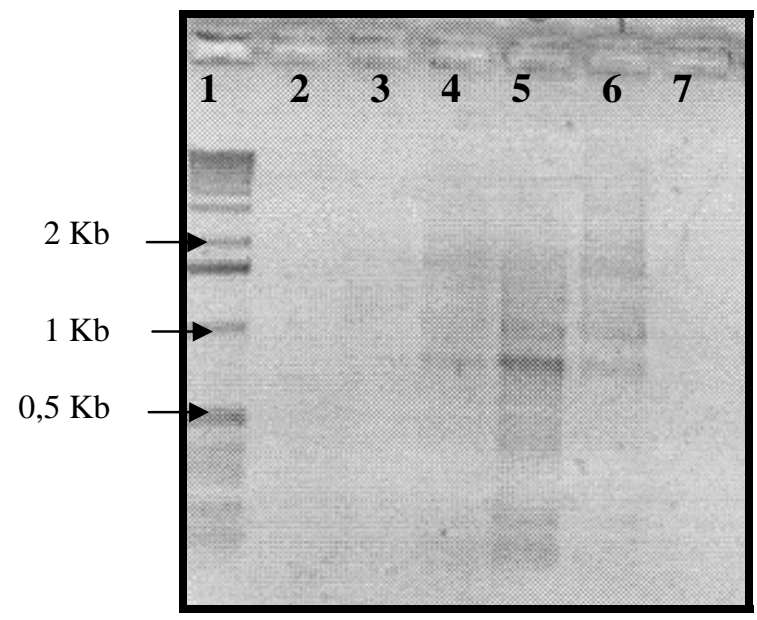

Figura 7 - Gel de agarose 1\% para visualização dos fragmentos amplificados pelo primer Lep_1 do gene da leptina. A canaleta 1 corresponde ao marcador de peso molecular $1 \mathrm{~Kb}$ ladder (Invitrogen) e as canaletas 2 a 7 são amostras de DNA usadas para teste de amplificação. O fragmento esperado era de 1856pb

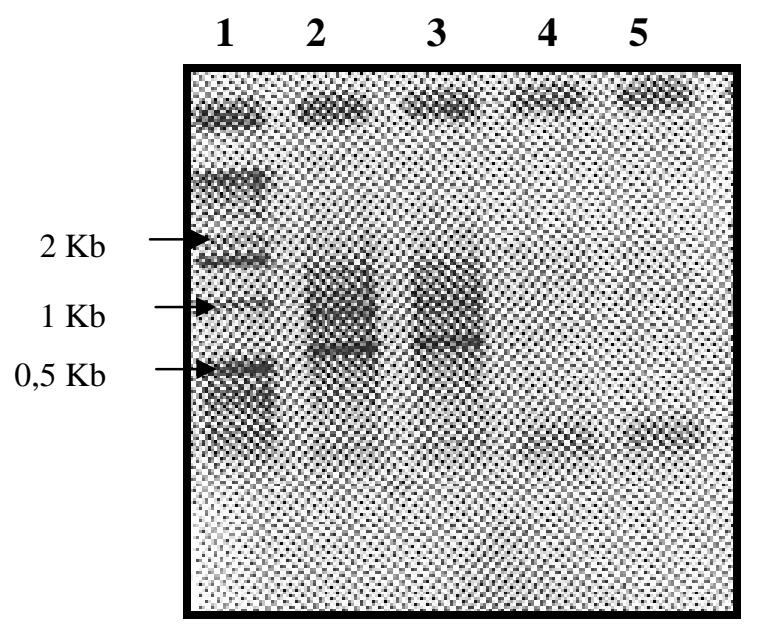

Figura 8 - Gel de agarose 1\% para visualização dos fragmentos amplificados pelo primer Lep_2 do gene da leptina. A canaleta 1 corresponde ao marcador de peso molecular $1 \mathrm{~Kb}$ ladder (invitrogen) e as canaletas 2 a 5 são amostras de DNA usadas para teste de amplificação. O fragmento esperado era de 2012pb 


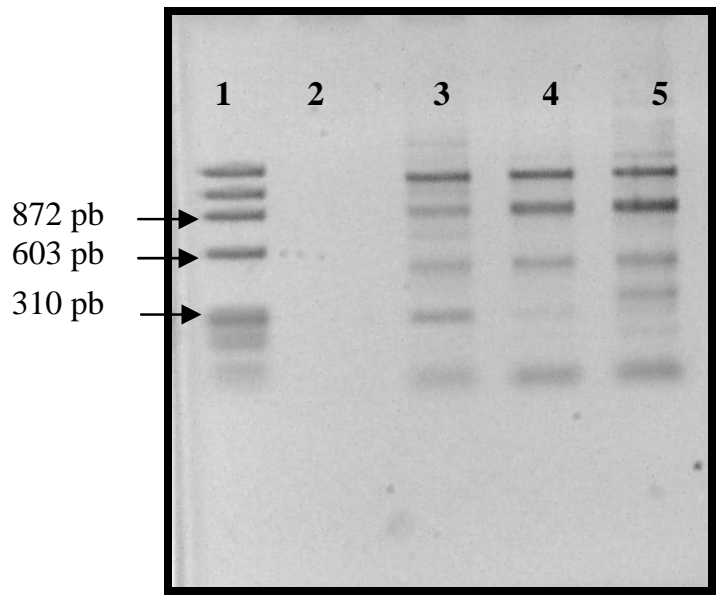

Figura 9 - Gel de agarose 1\% para visualização dos fragmentos amplificados pelo primer Lep_3 do gene da leptina. A canaleta 1 corresponde ao marcador de peso molecular $1 \mathrm{~Kb}$ ladder (invitrogen) e as canaletas 2 a 8 são amostras de DNA usadas para teste de amplificação. O fragmento esperado era de 272pb

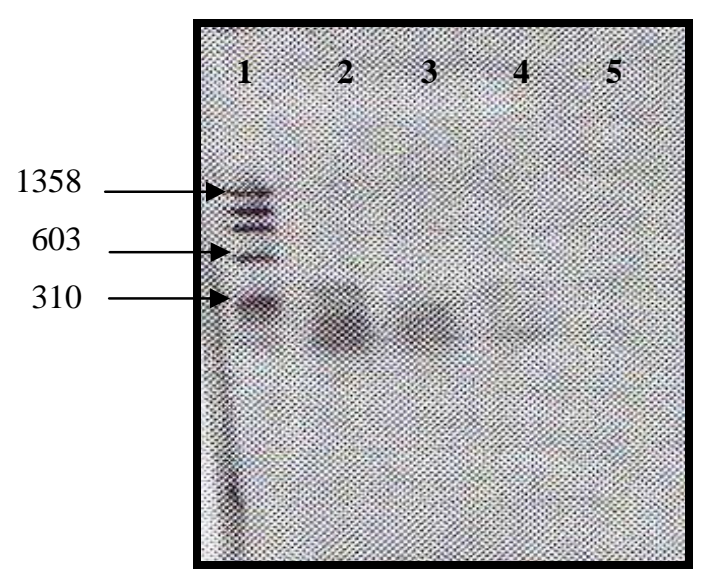

Figura 10 - Gel de agarose 1\% para visualização dos fragmentos amplificados pelo primer Lep_4 do gene da leptina. A canaleta 1 corresponde ao marcador de peso molecular $\phi x 174$ (Invitrogen) e as canaletas 2 a 5 são amostras de DNA usadas para teste de amplificação. O fragmento esperado era de 190pb 
No presente trabalho foram realizadas tentativas de amplificar o gene da leptina utilizando três pares de primers desenhados a partir da provável seqüência do gene da leptina descrita por Taouis et al. (1998) e o quarto par de primers foi descrito por Dridi et al. (2005) que verificaram a expressão hepática do gene da leptina em galinhas. Os quatro pares de primers foram submetidos a diversas condições de amplificação, no entanto, não foi possível identificar uma banda específica e nem do tamanho esperado. Outros autores, Friedman-Einat et al. (1999), na tentativa de amplificar o gene da leptina utilizando como referência os resultados obtidos por Taouis et al. (1998), desenharam 14 pares de primers em diversas regiões da suposta seqüência do gene da leptina em galinhas, sendo que quatro eram idênticos às seqüências de primers publicadas anteriromente. Esses experimentos foram realizados paralelamente em dois laboratórios pertencentes a diferentes instituições de pesquisa, porém não houve amplificação. Os testes foram realizados com cDNA do tecido hepático, pancreático e adiposo de camundongo, frango de corte, peru, ganso, codorna e bantam (galinha de pequeno porte). Houve amplificação do cDNA do tecido hepático de frango de corte e bantam, mas as bandas foram inespecíficas e nenhuma do tamanho esperado, mesmo assim foram seqüenciadas, mas não revelaram similaridade com a seqüência conhecida. Somente em camundongos foi obtido o fragmento esperado. Em adição, esses autores também usaram as estratégias de hibridização através da técnica de Northern e Southern Blot, mas não houve hibridização do RNA e DNA de nenhuma das aves, somente do gene GAPDH usado como controle.

Pitel et al. (1999) publicaram o mapeamento do gene da leptina da galinha no microcromossomo 7 a partir da seqüência descrita por Taouis et al. (1998). Entretanto, Pitel et al. (2000) ao sequenciarem o produto de PCR gerado pelos primers desenhados com base na seqüência descrita por Taouis et al. (1998) detectaram que a seqüência gerada não correspondia nem à seqüência publicada (TAOUIS et al.1998) nem a qualquer outra seqüência do genoma da galinha depositada no GenBank. Com base nesses dados, Pitel et al. (2000) comunicaram que na verdade o gene da leptina da galinha ainda não tinha sido mapeado, ao contrário do que eles mesmos haviam publicado anteriormente, uma vez que a localização do gene da leptina da galinha requereria a amplificação de um fragmento genômico, e isso era impossível usando os primers desenhados a partir da seqüência publicada. 
Recentemnte, Carre et al. (2006) não encontraram o gene da leptina entre 578,445 ESTs de frango analisadas. Além disso, não foi possível amplificar o gene da leptina com base nos primers publicados por Taouis et al. (1998).

Segundo Rosa e Giancheto ${ }^{1}$ (Informação pessoal), no Brasil um grupo de pesquisa da Universidade Estadual Paulista (UNESP) também realizou diversas tentativas de amplificação e clonagem do gene da leptina em galinhas, mas não obteve sucesso.

A alta similaridade da seqüência do gene da leptina de galinhas e camundongos é questionável. Segundo FRIEDMAN-EINANT et al. (1999) e DOYON et al. (2001), tal similaridade não está de acordo com a relação filogenética entre a seqüência nucleotídica da leptina em mamíferos e também de outros genes em mamíferos. Na Tabela 8 são apresentadas as comparações de porcentagem de similaridade de nucleotídeos dos genes da leptina, prolactina e interferon entre camundondo, rato, ovelha e galinha. Quando são comparadas as seqüências dos genes da prolactina e interferon (genes pertencentes à família das citocinas) entre os mamíferos, é encontratada uma similaridade menor do que os $94,6 \%$ encontrados entre a seqüência da leptina de camundongo e de galinha.

Tabela 8 - Comparação da porcentagem de similaridade de nucleotídeos dos genes da leptina, prolactina e interferon com camundongo, rato, ovelha e galinha

\begin{tabular}{|c|c|c|c|c|c|}
\hline Gene & & Camundongo & Rato & Ovelha & Galinha \\
\hline \multicolumn{6}{|l|}{ Leptina } \\
\hline & Camundongo & $100 \%$ & $95,6 \%$ & $83,3 \%$ & $94,6 \%$ \\
\hline & Rato & & $100 \%$ & $83,6 \%$ & $90,4 \%$ \\
\hline & Ovelha & & & $100 \%$ & $81,5 \%$ \\
\hline & Galinha & & & & $100 \%$ \\
\hline \multicolumn{6}{|l|}{ Prolactina } \\
\hline & Camundongo & $100 \%$ & $89,4 \%$ & $68,4 \%$ & $62,6 \%$ \\
\hline & Rato & & $100 \%$ & $71,3 \%$ & $65,7 \%$ \\
\hline & Ovelha & & & $100 \%$ & $67,3 \%$ \\
\hline & Galinha & & & & $100 \%$ \\
\hline \multicolumn{6}{|l|}{ Interferon } \\
\hline & Camundongo & $100 \%$ & $88,2 \%$ & $64,2 \%$ & $59,8 \%$ \\
\hline & Rato & & $100 \%$ & $65,4 \%$ & $56,4 \%$ \\
\hline & Ovelha & & & $100 \%$ & $57,2 \%$ \\
\hline & Galinha & & & & $100 \%$ \\
\hline
\end{tabular}

Tabela adapata de Friedman-Einant et al. (1999).

\footnotetext{
${ }^{1}$ ROSA, P.S.; GIANCHETTO, P. Mensagem recebida por < prosa@cnpsa.embrapa.br> e

<poliana.gianchetto@alellyx.com.br> em 20 de novembro de 2006
} 


\subsubsection{Extração e quantificação de RNA}

Foram realizadas diversas tentativas de amplificação do gene da leptina de Gallus gallus, porém não foi possível amplificar o gene a partir de DNA genômico. Sendo assim, optouse por tentar a amplificação a partir de cDNA, para isso foi feita a extração de RNA total de tecido adiposo e hepático de frangos de corte com 21 dias de idade. Após a extração, as amostras foram submetidas à eletroforese em gel de agarose $1 \%$ para a verificação da integridade do RNA total, conforme pode ser observado na Figura 11. A integridade do material foi avaliada pela presença das bandas estruturais de RNA ribossômico (28S, 18S e 5,8S). Cinco microgramas de RNA total de cada amostra foram utilizadas na síntese de cDNA empregado nas análises de PCR.

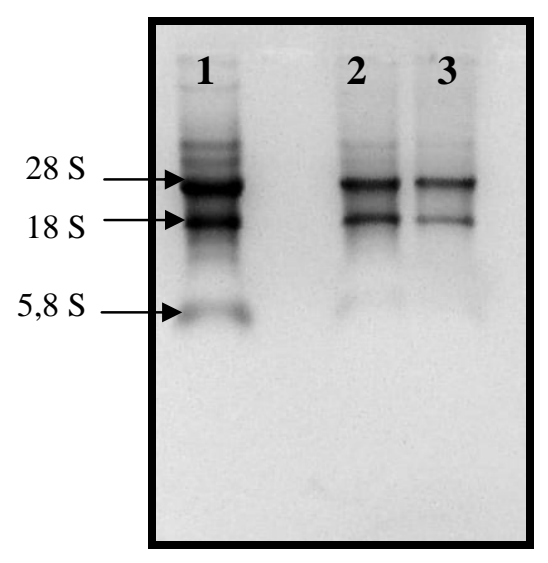

Figura 11 - Gel de agarose 1\% para verificação da integridade do RNA total, podendo-se visualizar as bandas estruturais de RNA ribossômico (28S e $18 \mathrm{~S}$ e 5,8S). A amostra 1 corresponde ao tecido hepático e as amostras 2 e 3 ao tecido adiposo

\subsubsection{RT-PCR}

Primeiramente foi realizada a reação de PCR para o gene constitutivo beta-actina (409 pb), utilizado como controle para verificação da integridade do cDNA (Figura 12). Depois de confirmada a integridade foram feitos alguns testes de gradiente de temperatura para a otimização das condições de amplificação do primer Lep_3. As amostras foram submetidas a um gradiente de temperatura variando de $45^{\circ} \mathrm{C}$ a $65{ }^{\circ} \mathrm{C}$, no entanto, não houve amplificação. $\mathrm{O}$ tamanho esperado do fragmento era de 272 pb (Figura 13). Os produtos amplificados foram visualizados em géis de agarose $1 \%$ para verificação do tamanho esperado dos produtos da PCR. 


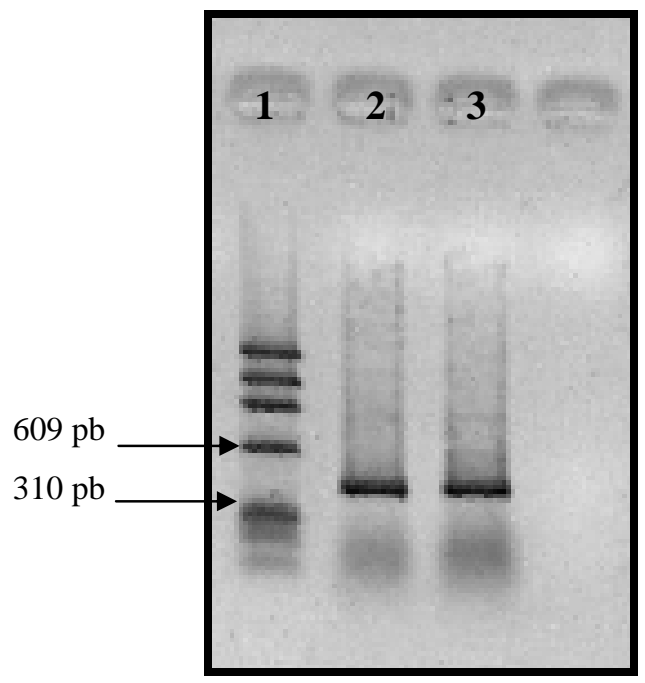

Figura 12 - Gel de agarose $1 \%$ para visualização do fragmento de 409 pb do gene da beta-actina. A canaleta 1 corresponde ao padrão de peso molecular $\phi \mathrm{x} 174$ (Invitrogen), as canaletas 2 e 3 correspondem as amostras de cDNA do tecido adipso e hepático respectivamente

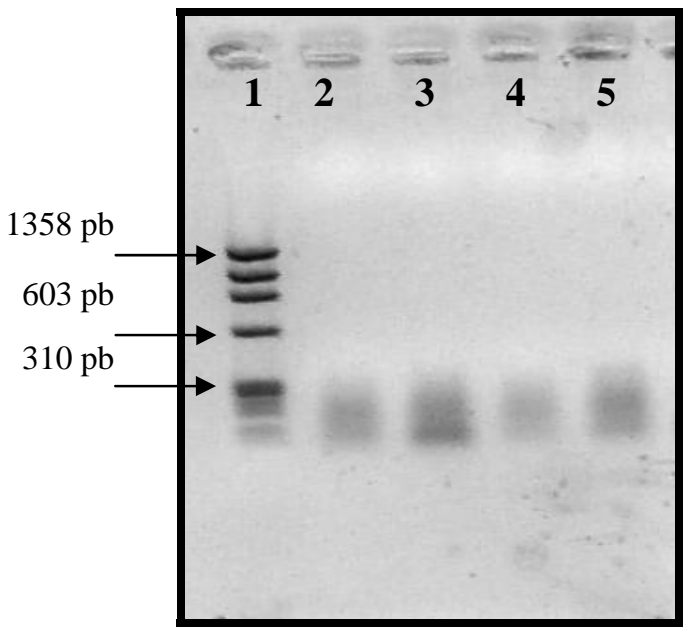

Figura 13 - Gel de agarose 1\% para visualização do fragmento amplificado pelo primer Lep_3 do gene da leptina. A canaleta 1 corresponde ao padrão de peso molecular $\phi x 174$ (Invitrogen), as canaletas 2 e 4 correspondem as amostras de cDNA do tecido adiposo e as canaletas 3 e 5 correspondem as amostras de cDNA do tecido hepático 
Após várias tentativas de amplificação do gene da leptina usando DNA e cDNA, não foi detectado o fragmento esperado. Esses resultados corroboram os resultados encontrados por Friedman-Einant et al. (1999), Pitel et al. (2000) e Carre et al. (2006), os quais tambem não tiveram sucesso na amplificaçao deste gene. Vale ressaltar que foram feitas buscas (utilizando-se a ferramenta BLAST - Basic Local Alignment Search Tool) pela suposta seqüência do gene da leptina de galinha (Taouis et al., 1998) no genoma de Gallus gallus (http://www.ncbi.nlm.nih.gov /genome/seq/BlastGen/BlastGen.cgi?taxid=9031), porém a seqüiência do gene não foi encontrada.

\subsection{Gene do receptor da leptina}

\subsubsection{Otimização das condições e amplificação por PCR}

As condições de amplificação das duas regiões do gene do receptor da leptina variaram apenas na temperatura de anelamento dos dois primers, sendo que para o primer RL_1 a temperatura foi de $60{ }^{\circ} \mathrm{C}$ e para o primer RL_2 de $64{ }^{\circ} \mathrm{C}$. As Figuras 14 e 15 são imagens de géis de agarose a $1 \%$, onde foram aplicados os produtos das PCRs para visualização do tamanho dos fragmentos amplificados. Os tamanhos esperados dos fragmentos são 750 e 940 pb, para os primers RL_1 e RL_2, respectivamente.

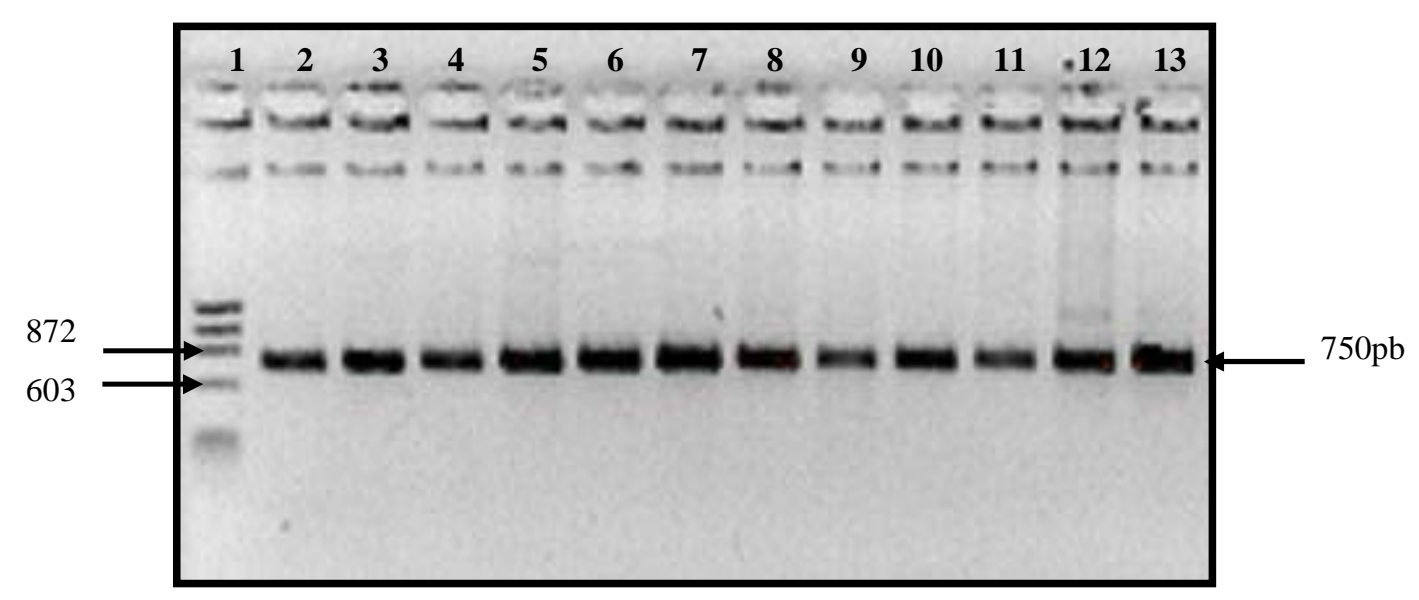

Figura 14 - Gel de agarose 1\% para visualização do fragmento amplificado pelo primer RL_1 do gene do receptor da leptina. A canaleta 1 corresponde ao padrão de peso molecular $\phi x 174$ (Invitrogen) e as canaletas 2 a 13 correspondem as amostras de DNA amplificadas da geração parental 


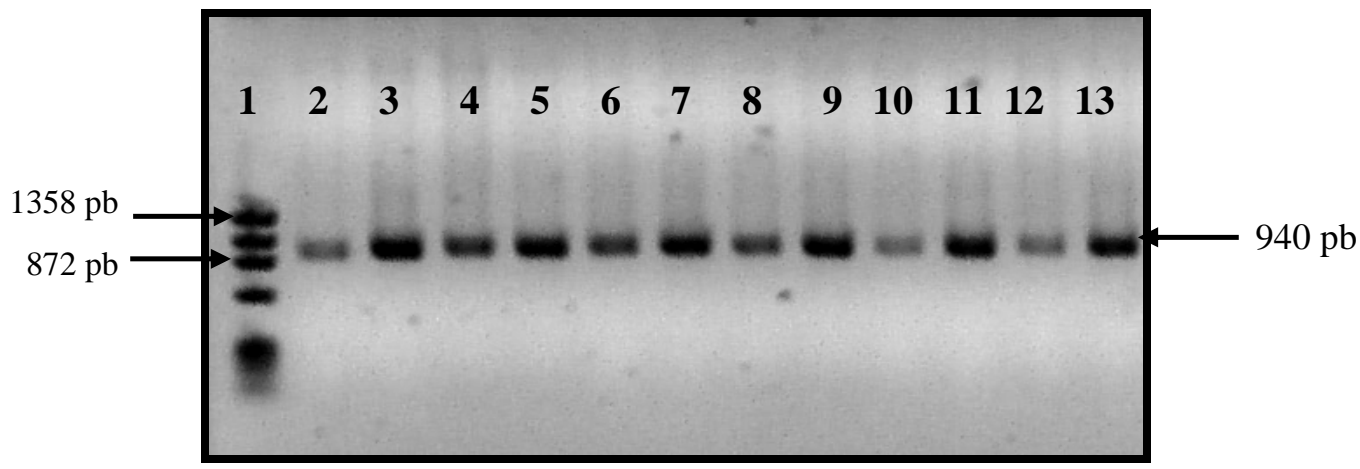

Figura 15 - Gel de agarose 1\% para visualização do fragmento amplificado pelo primer RL_2 do gene do receptor da leptina. A canaleta 1 corresponde ao padrão de peso molecular $\phi x 174$ (Invitrogen) e as canaletas 2 a 13 correspondem as amostras de DNA amplificadas da geração parental

\subsubsection{Purificação dos produtos da PCR}

Após a amplificação foi feita a purificação dos produtos da PCR do gene do receptor da leptina. As amostras purificadas foram submetidas à eletroforese em gel de agarose 1\% para verificação da concentração final dos produtos da PCR. Na Figura 16 pode-se observar a concentração homogênea das amostras.

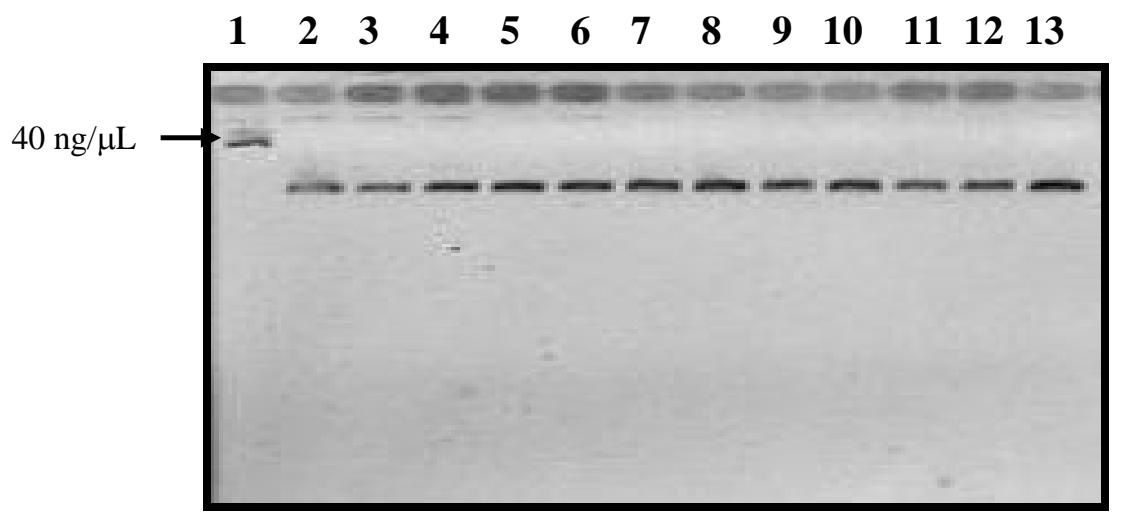

Figura 16 - Gel de agarose 1\% contendo amostras dos produtos da PCR purificados. A primeira canaleta corresponde ao pGEN4Z (40 ng/ $\mu \mathrm{L}$ ), as canaletas seguintes correspondem às amostras de DNA da geração parental 


\subsubsection{Seqüenciamento}

Após a reação de seqüenciamento, as amostras foram purificadas e aplicadas em seqüenciador automático ABI 3100 Applied Biosystems. Na Figura 17 pode-se observar o cromatrograma obtido no seqüenciamento dos produtos da PCR.

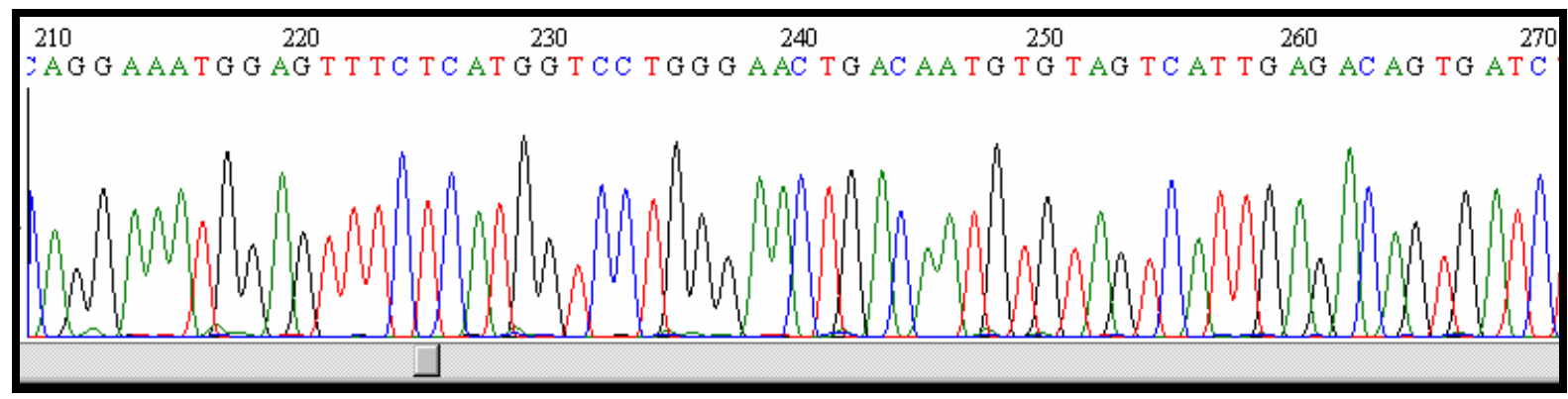

Figura 17 - Padrão do cromatrograma obtido no seqüenciamento dos produtos da PCR

\subsubsection{Análise das seqüências e escolha dos polimorfismos}

A análise de polimorfismos foi realizada por seqüenciamento em duas regiões do gene do receptor da leptina, no íntron 8 (primer RL_1) e no íntron 19 (primer RL_2). Inicialmente a análise foi realizada nos parentais da população referência F2 TCTC: seis machos TT e seis fêmeas CC. Os polimorfismos encontrados nos parentais foram confirmados por meio de seqüenciamento das amostras correspondentes aos 20 animais da geração F1. Foram efetuadas duas reações de seqüenciamento para cada indivíduo, uma utilizando o primer direto e outra o reverso.

No íntron 8, foram identificados doze polimorfismos de uma única base (SNP), que são apresentados nos Anexos A e B. Em média ocorreram 1,6 SNPs por 100 pares de base, média também encontrada por Weigend e Romanov (2001), já Vignal et al. (2002) encontraram um SNP a cada 200 pb, porém Rosthschild e Soller (1999) descrevem que a ocorrência de um polimorfismo a cada 700-1000 pb estaria dentro de uma média aceitável. Desses doze polimorfismos, somente seis ocorreram em um maior número de indivíduos. Na Tabela 9 é apresentada a freqüência destes polimorfismos nas linhagens CC e TT. As substituições, C $\rightarrow$ T na posição 352 (C352T) e A $\rightarrow \mathrm{G}$ na posição 660 (A660G), ocorreram somente nos seis animais da linhagem TT. Dois polimorfismos, $T \rightarrow C$ na posição 508 (T508C) e $G \rightarrow A$ na posição 523 (G523A), ocorreram somente em três animais da linhagem CC. Outros dois polimorfismos, $\mathrm{T} \rightarrow \mathrm{C}$ 
na posição 336 (T336C) e $A \rightarrow G$ na posição 427 (A427G), ocorreram em ambas linhagens, porém, com maior freqüência na linhagem CC. A localização dos SNPs citada acima, é em relação a seqüência depositada no GenBank (AF222783). A seqüência consenso gerada a partir do alinhamento dos parentais e F1 e seus respectivos polimorfismos é apresentada na Figura 18.

Tabela 9 - Freqüência de polimorfismos nas linhagens TT e CC encontrados no íntron 8 do gene do receptor da leptina

\begin{tabular}{ccccc}
\hline Linhagem & Posição & Nucleotídeo Consenso & Nucleotídeo Mutante & Freqüência (\%) \\
\hline CC & 336 & $\mathrm{~T}$ & $\mathrm{C}$ & 50 \\
TT & 336 & $\mathrm{~T}$ & $\mathrm{C}$ & 16,7 \\
CC & 352 & $\mathrm{C}$ & $\mathrm{T}$ & 0 \\
TT & 352 & $\mathrm{C}$ & $\mathrm{T}$ & 100 \\
CC & 427 & $\mathrm{~A}$ & $\mathrm{G}$ & 83 \\
TT & 427 & $\mathrm{~A}$ & $\mathrm{G}$ & 16,7 \\
CC & 508 & $\mathrm{~T}$ & $\mathrm{C}$ & 50 \\
TT & 508 & $\mathrm{~T}$ & $\mathrm{C}$ & 0 \\
CC & 523 & $\mathrm{G}$ & $\mathrm{A}$ & 50 \\
TT & 523 & $\mathrm{G}$ & $\mathrm{A}$ & 0 \\
CC & 660 & $\mathrm{~A}$ & $\mathrm{G}$ & 0 \\
TT & 660 & $\mathrm{~A}$ & $\mathrm{G}$ & 100 \\
\hline
\end{tabular}

ATGAGCACACTGTATAATCTGAATGTGGGAGGTAGGTCACGTGCAGTCACCTTGAGCAGTAAGTAGACT TCTGGGATGCAGTGTATTTTCCAATTTTTGTTTTGTGGAATCAGTATGTGTGAGAACGTTATCCGGGAGC TGCAGCACACTGTGTGCACGAGTTGGACTAAGAATTCCCATGGAAGCTCTTTAACT ${ }^{1}$ TTCTGCTTCTCCT $^{-}$ GCC ${ }^{2}$ GCGTAGCTTTGCCTGAGGTTGTGCTCTTTCCTTTGTAGAAGATTAGCATTAAATGATAAATGCATG GAGACTGCA ${ }^{3}$ CGGTGATCTCCATGACACCCCCATGTCTGGCCCTATTGCTTTCAGACCCAGGAGAAGCTG GGCTTTTCACTTATGCTGCT ${ }^{4}$ GTGTGTTGTTTTCAG $^{5}$ TGTACTGCCCGGGTGTTTTCTGTCAGTTCATTACC ATTTGCCTAGGGACAGTAAAGGTTATTTTTATTAGAACTTGTAAACATGAGTTATGGAATGAAACAGTC AAGGATCTGTTCCTGCTCCTCTGCCCTATAGCAA ${ }^{6}$ TTCGTAATAACAAACCTGGAAGAAGCAGATGATGT AGAGATACTACGGGATAATAGGAATTCTCTGTTGCTCTGTAGTTTTTGTTGTTGTTCTGATTCTGATCTC AGTGGATTTCTTTCTTTTCTTGTAGCTGAAGTGCTGTACTTCCCTACTAAGATACTGACCAGTGTTGGTTC TAACGTTTCGTTTCATTGCATCTATAAAAACAAACCCAGAGCGTA

Figura 18 - Seqüência consenso gerada a partir do sequenciamento do fragmento amplificado com o primer Rlep_1 para os animais da geração parental e F1 e seus respectivos polimorfismos: $1-\mathrm{T} \rightarrow \mathrm{C}$ polimorfismo (T336C), 2 - $\mathrm{C} \rightarrow$ T polimorfismo (C352T), 3 - A $\rightarrow$ G polimorfismo (A427G), 4 - $\mathrm{T} \rightarrow \mathrm{C}$ polimorfismo (T508C), 5 - G $\rightarrow$ A polimorfismo (G523A), 6 - A $\rightarrow$ G polimorfismo (A660G). 
Na região estudada do íntron 19, foram identificados seis polimorfismos, os quais são apresentados nos Anexos C e D. Nesta região foi encontrado em média 0,7 polimorfismos em 100 pb. Na Tabela 10 é apresentada a freqüência destes polimorfismos na linhagem CC e TT. Dos seis polimorfismos, cinco eram SNPs. Os polimorfismos G $\rightarrow$ A na posição 326 (G326A), G $\rightarrow$ A na posição 440 (G440A) e G $\rightarrow$ T na posição 927 (G927T) ocorreram em três animais da linhagem CC. Os polimorfismos $T \rightarrow C$ na posição 646 (T646C) e $G \rightarrow A$ na posição 915 (G915A), ocorreram em dois animais da linhagem CC. O sexto polimorfismo é uma deleção/inserção das bases GGAAG na posição 633 (GGAAG633deleção/inserção) e ocorreu nos seis animais da linhagem TT e em três da linhagem CC. A localização dos SNPs citada acima, é em relação a seqüência depositada no GenBank (AY348718S2). A seqüência consenso gerada a partir do alinhamento dos parentais e F1 e seus respectivos polimorfismos é apresentada na Figura 19.

Tabela 10 - Freqüência de polimorfismos nas linhagens CC e TT encontrados no íntron 19 do gene do receptor da leptina

\begin{tabular}{ccccc}
\hline Linhagem & Posição & Nucleotídeo Consenso & Nucleotídeo Mutante & Freqüência (\%) \\
\hline CC & 326 & G & A & 50 \\
TT & 326 & G & A & 0 \\
CC & 440 & G & A & 50 \\
TT & 440 & G & A & 0 \\
CC & 633 & GGAAG & Deleção & 50 \\
TT & 633 & GGAAG & Deleção & 100 \\
CC & 646 & T & C & 33,3 \\
TT & 646 & T & C & 0 \\
CC & 915 & G & A & 33,3 \\
TT & 915 & G & A & 0 \\
CC & 927 & G & A & 50 \\
TT & 927 & G & A & 0 \\
\hline
\end{tabular}


GAGACCCATCTGTCGATGCAGCACATGAGTTGTAGAATCCAAACGTGTCCCATCG ${ }^{1}$ GTGTAATGCTCCTG TGGCACTGATGGGTGCCGTGCTTGTAGCGGTGGCTGTATGTTTTGCTGGAGTAAACTGCCTCTCTATTTA CCACGTGAATCAAGAGCTGTGATGCAATGG ${ }^{2}$ GCTGTGACCAGTGAGAGCCTTTATGTGGACATAACCCC TTTGCACCAGGAAATGGAGTTTCTCATGGTCCTGGGAACTGACAATGTGTAGTCATTGAGACAGTGATC TAAATTAGGCCTGTTATTTCTAAAATAAAGAGCACCTAATGACAGAAGATTTCTTTGGGGTATTTTAGTT

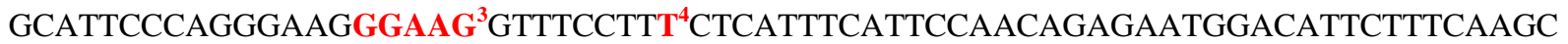
CTAATCATGGTCACTGCCTGCTCGAACCTTTGGGCCATCTCCCAGGCTTCCTAGGGTTAGAAGGTTTTTC TATTTATATTCAGAAGACAGGAAACACAGACACCTTATGATGCTCATTTGCTTAATTATAATGAATCGC AGAAGTAGCTCTGTCAAAAATCTAAACTACCCTTGCAAAAATTCGGAGTAGGTGCCGTGTTACAGACCA GAACATGGCTTGTCACTTGTACG ${ }^{5}$ AGGTTCTGCTG $^{6}$ TAAGATCTTCTGAAGTTTTTACGTGCCCCTGGTGC AGCAGCAGCAACTCAGAGAATGCAGATACTGTGTGCATGTTGTGTCTTGGTTGGTTTTTTTTTACTTGAT TTTTTTTTTTTCCTGAAGGTTCCAACATGAATGCTATTTATATGGCTTCTTTATTCGTTATCATTCAAACA AGCAGCTGTATCAGTGCAAATGTCTGAATCATCTTGAGGGTTAAAAATAAGCAAGCAAAAATCCCCAA GCAC

Figura 19 - Seqüência consenso gerada a partir do sequenciamento do fragmento amplificado com o primer Rlep_2 para os animais da geração parental e F1 e seus respectivos polimorfismos: 1 - G $\rightarrow$ A polimorfismo (G326A), 2 - G $\rightarrow$ A polimorfismo (G440A), 3 - GGAAG $\rightarrow$ deleção/inserção polimorfismo (GGAAG633deleção/inserção), 4 - T $\rightarrow$ C polimorfismo (T646C), 5 - G $\rightarrow$ A polimorfismo (G915A), 6 - G $\rightarrow$ T polimorfismo (G927T)

As seqüências consenso obtidas, nas duas regiões seqüenciadas, foram comparadas às depositadas no banco de SNPs do NCBI (http://www.ncbi.nlm.nih.gov/SNP/snp blastByOrg.cgi) e dois polimorfismos encontram-se depositados no banco de dados: o SNP C352T, que ocorreu no íntron 8, está depositado com o número de acesso rs14657347 e o SNP G440A, localizado no íntron 19, depositado com o número de acesso rs14657359.

A escolha dos polimorfismos a serem genotipados foi baseada na ocorrência dos mesmos em famílias F1 informativas, bem como famílias F1 já estudadas pelo grupo de pesquisa e na identifição de sítios de restrição nas seqüências. Os polimorfismos selecionados foram o C352T no íntron 8 e G915A no íntron 19.

\subsection{Genotipagem de polimorfismos no gene RLep}

O polimorfismo C352T foi selecionado para ser genotipado em quatro famílias F1 informativas, perfazendo um total de 247 aves genotipadas. Foram selecionadas as famílias 7765, 7810, 7978 e 7798 sendo que as três primeiras fazem parte de um estudo de QTL que está sendo conduzido no Laboratório de Biotecnologia Animal. Uma vez que para este loco não foi encontrado sítio para enzima de restrição, a genotipagem foi realizada por seqüenciamento. 
A genotipagem do polimorfismo G915A encontrado no íntron 19 foi realizada pela técnica de PCR-RFLP, usando a enzima de restrição Bsp1407I. Para este sítio polimórfico foram encontradas somente duas famílias F1 informativas: 7713 e 7972, resultando em apenas 137 animais. Essas famílias são formadas por casais heterozigotos e já foram utilizadas pela equipe em estudos de genes candidatos. A reação de amplificação do fragmento do íntron 19 resultou em um fragmento de 940pb, sendo que a digestão com a enzima Bsp1407I resultou três fragmentos: 940, 674, e 266 pb. A Figura 20 mostra o padrão de bandas do polimorfismo após a digestão seguida pela eletroforese em gel de agarose 1\%. Os indivíduos homozigotos GG apresentaram somente uma banda de 940 pb, os homozigotos AA duas bandas, a primeira de 674 pb e a segunda de 266 pb e os indivíduos heterozigotos GA apresentaram três bandas, a primeira de 930 pb, a segunda de 674 e a terceira de $266 \mathrm{pb}$.

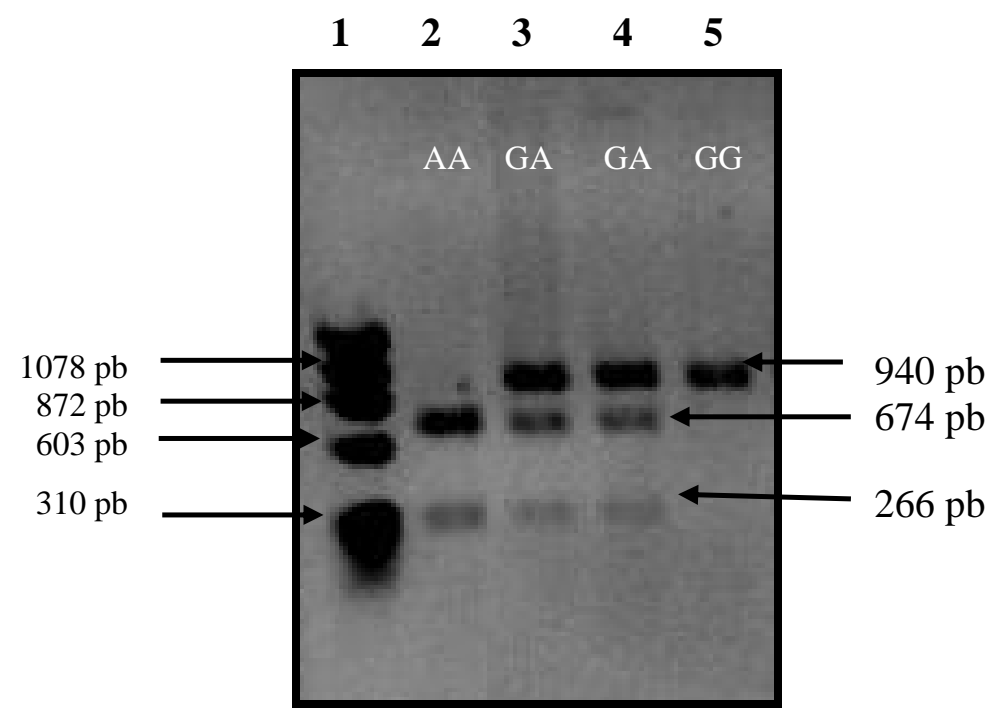

Figura 20 - Padrão de fragmentos do produto amplificado do íntron 19 do gene do receptor da leptina digerido com a enzima Bsp1407I. A canaleta 1 corresponde ao padrão de peso molecular $\phi x 174$ (Invitrogen), a canaleta 2 ao homozigoto AA, as canaletas 3 e 4 aos genótipos heterozigotos GA e a canaleta 5 ao genótipo homozigoto GG 


\subsection{Análise estatística}

\subsubsection{Freqüências genotípicas}

O SNP C352T foi genotipado nas famílias 7765 (n=58), 7810 (n=67), 7978 (75) e 7798 (47), num total de 247 animais. Foi realizada uma análise de frequência dos genótipos nos 247 animais avaliados, sendo que os genótipos CC, CT e TT foram encontrados, este resultado já era esperado, pois as quatro famílias selecionadas eram formadas por casais heterozigotos, gerando assim animais F2 com os três genotipos (CC, CT e TT). As frequências dos genótipos foram semelhantes entre os sexos e entre as famílias. O SNP G915A foi genotipado nas famílias 7972 (n=86) e 7713 (n=51) somando 137 animais. Na análise de freqüência os genótipos GG, GA e AA estavam distribuídos de modo semelhante entre os sexos e entre as famílias. Na Tabela 11 é apresentada a freqüência de genótipos dos SNPs C352T e G915A.

Tabela 11 - Freqüência de genótipos nas famílias da população F2 TCTC avaliadas em relação aos SNPs C352T e G915A

\begin{tabular}{cccc}
\hline \multirow{2}{*}{ SNP C352T } & Genótipo & Freqüência & Porcentagem (\%) \\
\cline { 2 - 4 } & & 58 & 23,48 \\
CC & 122 & 49,39 \\
CT & 67 & 27,13 \\
TT & 247 & 100 \\
\hline Total & & \\
& GG G915A & 35 & 25.55 \\
& GA & 70 & 51.09 \\
AA & 32 & 23.36 \\
& Total & 137 & 100 \\
\hline
\end{tabular}




\subsubsection{Análise de variância}

A Tabela 12 apresenta os resultados da análise de associação entre o SNP C352T e as características avaliadas para desempenho, carcaça, composição de carcaça e características relacionadas a gordura. O efeito de incubação foi significativo para a maioria das características avaliadas, exceto para RPUL. Este resultado era esperado, visto que os animais F2 foram gerados em 17 incubações, o que levou cerca de oito meses. O efeito de família não foi significativo para GP, RCARC, RPEIT, RCOR, RPUL, PB_MN, CZ(g), COL e TRIGLI. O efeito de sexo foi significativo para a maioria das características, exceto para RCOR, RPUL, MS, UM, PB_MN, PB_MS, CZ_MN, CZ_MS, RGA, RFIG, EE_MN e EE_MS. O efeito de genótipo do SNP C352T influenciou significativamente apenas o RFIG. Já as características RCARC, RPEIT, PB e CZ foram influenciadas significativamente pela interação entre sexo e genotipo, indicando que o efeito dos genótipos do SNP C352T sob essas características é dependente do sexo do animal, os genótipos se expressam de maneira diferente nos sexos para essas características.

Tabela 12 - Probabilidades obtidas na análise de variância para as características de desempenho, carcaça, composição de carcaça e características relacionadas à gordura avaliadas para o SNP C352T

(continua)

\begin{tabular}{|c|c|c|c|c|c|c|}
\hline Característica & $\mathbf{n}$ & Incubação & Família & Sexo & Genótipo & Sexo x Genótipo \\
\hline \multicolumn{7}{|l|}{ Desempenho } \\
\hline PN (g) & 246 & $<.0001$ & $<.0001$ & 0.0072 & NS & NS \\
\hline P35 (g) & 247 & $<.0001$ & 0.0004 & $<.0001$ & NS & NS \\
\hline P42 (g) & 247 & $<.0001$ & 0.0007 & $<.0001$ & NS & NS \\
\hline GP (g) & 245 & $<.0001$ & NS & $<.0001$ & NS & NS \\
\hline CR (g) & 247 & $<.0001$ & 0.0052 & $<.0001$ & NS & NS \\
\hline EA & 240 & $<.0001$ & 0.0363 & $<.0001$ & NS & NS \\
\hline \multicolumn{7}{|l|}{ Carcaça } \\
\hline RCARC (\%) & 247 & $<.0001$ & NS & NS & NS & 0.0165 \\
\hline RPEIT (\%) & 247 & 0.0038 & NS & 0.0088 & 0.0129 & 0.0137 \\
\hline RCOXA (\%) & 247 & $<.0001$ & 0.0492 & $<.0001$ & NS & NS \\
\hline RCOR (\%) & 247 & $<.0001$ & NS & NS & NS & NS \\
\hline RPUL (\%) & 247 & NS & NS & NS & NS & NS \\
\hline RFIG (\%) & 247 & $<.0001$ & 0.0530 & NS & 0.0102 & NS \\
\hline RMO (\%) & 247 & $<.0001$ & $<.0001$ & 0.0008 & NS & NS \\
\hline CI (cm) & 247 & $<.0001$ & 0.0084 & $<.0001$ & NS & NS \\
\hline
\end{tabular}


Tabela 12 - Probabilidades obtidas na análise de variância para as características de desempenho, carcaça, composição de carcaça e características relacionadas à gordura avaliadas para o SNP C352T

(conclusão)

\begin{tabular}{lcccccc}
\hline Característica & n & Incubação & Família & Sexo & Genótipo & Sexo x Genótipo \\
\hline Composição de Carcaça & & & & & & \\
MS (\%) & 238 & $<.0001$ & $<.0001$ & NS & NS & NS \\
UM (\%) & 238 & $<.0001$ & $<.0001$ & NS & NS & NS \\
PB (g) & 238 & 0.0002 & 0.0003 & $<.0001$ & NS & 0.0112 \\
PB_MN (\%) & 238 & $<.0001$ & NS & NS & NS & NS \\
PB_MS (\%) & 238 & $<.0001$ & $<.0001$ & NS & NS & NS \\
CZ (g) & 238 & $<.0001$ & NS & $<.0001$ & 0.0402 & 0.0150 \\
CZ_MN (\%) & 238 & $<.0001$ & 0.0204 & NS & NS & NS \\
CZ_MS (\%) & 238 & $<.0001$ & $<.0001$ & NS & NS & NS \\
Gordura & & & & & & \\
RGA (\%) & 247 & $<.0001$ & $<.0001$ & NS & NS & NS \\
EE (g) & 238 & $<.0001$ & $<.0001$ & $<.0001$ & NS & NS \\
EE_MN (\%) & 238 & $<.0001$ & $<.0001$ & NS & NS & NS \\
EE_MS (\%) & 238 & $<.0001$ & $<.0001$ & NS & NS & NS \\
COL (mg/dL) (\%) & 238 & $<.0001$ & NS & $<.0001$ & NS & NS \\
TRIGLI (mg/dL) (\%) & 235 & $<.0001$ & NS & 0.0019 & NS & NS \\
\hline
\end{tabular}

NS - P >0,05, PN - peso ao nascer, P35 e P42 - peso aos 35 e 42 dias de idade, GP - ganho de peso dos 35 aos 41 dias de idade, CR - consumo de ração dos 35 aos 41 dias de idade, EA - eficiência alimentar dos 35 aos 41 dias de idade, RCARC - rendimento de carcaça, RPEITO - rendimento de peito, RCOXA - rendimento de coxa e sobre coxa, RCOR - rendimento de coração, RPUL - rendimento de pulmão, RFIG - rendimento de fígado, RMO rendimento de moela, CI - comprimento de intestino, MS - matéria seca, UM - umidade, PB - proteína bruta, PB_MN - proteína bruta na matéria natural, PB_MS - proteína bruta na matéria seca, CZ - cinza, CZ_MN - cinza na matéria natural, CZ_MS - cinza na matéria seca, RGA - rendimento de gordura abdominal, EE - extrato etéreo, EE_MN - extrato etéreo na matéria natural, EE_MS - extrato etéreo na matéria seca, COL - colesterol, TRIGLI triglicerídeos 
Os resultados da análise de variância do SNP G915A com as características de desempenho, carcaça, composição de carcaça e características relacionadas a gordura são apresentados na Tabela 13. O efeito de incubação foi significativo para a maioria das características avaliadas, porém para as características de CR, RCOR, RPUL, CZ_MN, CZ, e TRIGLI o efeito não foi significativo. O efeito de família também foi significativo para a maioria das características avaliadas, só não foi significativo para as características de GP, CR, EA, RPUL, RMO, PB_MN, RFIG e TRIGLI. O efeito de sexo foi significativo para a maioria das características avaliadas, com exceção do PN, RCOR, RMO, PB_MN, CZ_MN e RFIG. Para o SNP G915A um número menor de características foi significativo para todos os efeitos analisados. Possivelmente isso ocorreu porque foram genotipadas somente duas famílias, consequentemente um número menor de animais os quais foram gerados em 10 incubações, diferindo do SNP C352T. O efeito de genótipo do SNP G915A foi significativo para CR, RCOXA e RPUL.

Tabela 13 - Probabilidades obtidas na análise de variância para as características de desempenho, carcaça, composição de carcaça e características relacionadas à gordura avaliadas para o SNP G915A

(continua)

\begin{tabular}{lcccccc}
\hline Característica & $\mathbf{n}$ & Incubação & Família & Sexo & Genótipo & Sexo x Genótipo \\
\hline Desempenho & & & & & & \\
PN (g) & 137 & $<.0001$ & $<.0001$ & NS & NS & NS \\
P35 (g) & 137 & 0.0063 & 0.0075 & $<.0001$ & NS & NS \\
P42 (g) & 137 & 0.0016 & 0.0001 & $<.0001$ & NS & NS \\
GP (g) & 137 & 0.0011 & NS & $<.0001$ & NS & NS \\
CR (g) & 137 & NS & NS & $<.0001$ & 0.0339 & NS \\
EA & 135 & 0.0051 & NS & 0.0265 & NS & NS \\
Carcaça & & & & & & \\
RCARC (\%) & 137 & $<.0001$ & $<.0001$ & 0.0037 & NS & NS \\
RPEIT (\%) & 137 & $<.0001$ & $<.0001$ & 0.0318 & NS & NS \\
RCOXA(\%) & 137 & 0.0009 & 0.0017 & $<.0001$ & 0.0302 & NS \\
RCOR (\%) & 137 & NS & 0.0025 & NS & NS & NS \\
RPUL (\%) & 137 & NS & NS & 0.0027 & 0.0287 & NS \\
RFIG (\%) & 137 & 0.0015 & NS & NS & NS & NS \\
RMO (\%) & 137 & 0.0076 & NS & NS & NS & NS \\
CI (cm) & 137 & 0.0057 & $<.0001$ & $<.0001$ & NS & NS
\end{tabular}


Tabela 13 - Probabilidades obtidas na análise de variância para as características de desempenho, carcaça, composição de carcaça e características relacionadas à gordura avaliadas para o SNP G915A

(conclusão)

\begin{tabular}{lcccccc}
\hline Característica & n & Incubação & Família & Sexo & Genótipo & Sexo x Genótipo \\
\hline Composição de Carcaça & & & & & & \\
MS (\%) & 129 & $<.0001$ & 0.0248 & 0.0012 & NS & NS \\
UM (\%) & 129 & $<.0001$ & 0.0248 & 0.0012 & NS & NS \\
PB (g) & 129 & $<.0001$ & 0.0042 & $<.0001$ & NS & NS \\
PB_MN (\%) & 129 & $<.0001$ & NS & NS & NS & NS \\
PB_MS (\%) & 129 & $<.0001$ & $<.0001$ & 0.0007 & NS & NS \\
CZ (g) & 129 & NS & 0.0488 & $<.0001$ & NS & NS \\
CZ_MN (\%) & 129 & NS & 0.0003 & NS & NS & NS \\
CZ_MS (\%) & 129 & $<.0001$ & 0.0405 & 0.0012 & NS & NS \\
Gordura & & & & & & \\
RGA (\%) & 137 & $<.0001$ & $<.0001$ & 0.0012 & NS & NS \\
EE_MN (\%) & 129 & $<.0001$ & 0.0002 & 0.0002 & NS & NS \\
EE_MS (\%) & 129 & $<.0001$ & $<.0001$ & 0.0014 & NS & NS \\
EE (g) & 129 & $<.0001$ & $<.0001$ & 0.0003 & NS & NS \\
COL (mg/dL) & 134 & 0.0130 & 0.0008 & $<.0001$ & NS & NS \\
TRIGLI (mg/dL) & 133 & NS & NS & 0.0046 & NS & NS \\
\hline
\end{tabular}

NS - P >0,05, PN - peso ao nascer, P35 e P42 - peso aos 35 e 42 dias de idade, GP - ganho de peso dos 35 aos 41 dias de idade, CR - consumo de ração dos 35 aos 41 dias de idade, EA - eficiência alimentar dos 35 aos 41 dias de idade, RCARC - rendimento de carcaça, RPEIT - rendimento de peito, RCOXA - rendimento de coxa e sobre coxa, RCOR - rendimento de coração, RPUL - rendimento de pulmão, RFIG - rendimento de fígado, RMO - rendimento de moela, CI - comprimento de intestino, MS - matéria seca, UM - umidade, PB - proteina bruta, PB_MN proteína bruta na matéria natural, PB_MS - proteína bruta na matéria seca, CZ - cinza, CZ_MN - cinza na matéria natural, CZ_MS - cina na matéria seca, RGA - rendimento de gordura abdominal, EE - extrato etéreo, EE_MN extrato etéreo na matéria natural, EE_MS - extrato etéreo na matéria, COL - colesterol, TRIGLI - triglicerídeos 


\subsubsection{Associações para o SNP C352T}

$\mathrm{O}$ rendimento de figado foi influenciado significativamente $(\mathrm{P}=0,0102)$ pelo genótipo do SNP C352T. Animais com genótipo homozigoto CC tiveram o rendimento de fígado maior do que os genótipos CT e TT, sendo que neste loco houve efeito de dominância significativo (Tabela 14). O alelo C é proveniente da linhagem de postura, quando em homozigose está relacionado a um maior peso de figado em relação ao peso vivo. O alelo T, proveniente da linhagem de corte, apresenta um efeito de dominância sobre o alelo C, visto que o heterozoigoto CT apresenta RFIG inferior a CC. Essas diferenças nas proporções de peso de figado em relação ao peso vivo sugerem que as aves de postura apresentam um maior metabolismo no figado em relação às aves de corte. Uma possível explicação para isso é o fato de que a geração F2 estudada foi criada como frango de corte, onde a ração é fornecida a vontade e também o nível de proteína e energia metabolizável é maior do que os requeridos por uma linhagem de postura. Consequentemente, estas aves apresentam maior peso de fígado em relação ao peso vivo.

Wang et al. (2004) também estudaram o íntron 8, porém em linhagens de frangos de corte selecionados divergentemente para gordura abdominal a sete semanas de idade. Foram encontrados dois SNPs associados com peso de gordura abdominal, porcentagem de gordura abdominal e peso de fígado. Em nossos resultados não foi verificada associação do SNP com porcentagem de gordura abdominal, possivelmente porque as linhagens fundadoras da nossa população, apesar de diferirem quanto à deposição de gordura, não foram selecionadas divergentemente para deposição de gordura o que diminui o poder de se detectar associação, quando comparando populações que sofreram seleção divergente para a característica em questão.

Tabela 14 - Médias estimadas dos genótipos para rendimento de fígado

\begin{tabular}{|c|c|c|c|c|}
\hline \multirow[t]{2}{*}{ Característica } & & \multicolumn{3}{|c|}{ Genótipos } \\
\hline & & $\mathbf{C C}$ & CT & TT \\
\hline Rendimento de Fígado (RFIG) & & $2.89 \pm 0.046$ & $2.74 \pm 0.034$ & $2.78 \pm 0.042$ \\
\hline Contrastes & & & & \\
\hline Dominância & $\begin{array}{l}\text { Prob t } \\
0.0139 \\
\end{array}$ & & $0.099 \pm 0.040$ & \\
\hline
\end{tabular}


Para a característica de rendimento de peito os genótipos apresentaram diferenças significativas nos machos ( $\mathrm{P}=0,0137)$, associados a um efeito aditivo de 0,45 gramas a cada alelo mutante $\mathrm{T}$ adicionado ao genótipo (Figura 21a). $\mathrm{O}$ alelo $\mathrm{T}$ tem origem na linhagem de corte, que foi selecionada para um maior rendimento de peito. Entre as diversas espécies de aves, o rendimento de peito é superior nas fêmeas (STRINGHINI et al., 2003; RIBEIRO et al., 2000), no presente trabalho o rendimento de peito foi maior nas fêmeas do que nos machos, mas somente para os genótipos CC e CT. Machos e fêmeas de genótipo TT apresentaram rendimento de peito semelhante. Uma hipótese para explicar esses resultados pode ser que esses polimorfismos estejam associados a genes ligados ao sexo, bem como a maior pressão de seleção para a característica considerada na linhagem de corte.

Da mesma maneira, o rendimento de carcaça foi influenciado pelo genótipo do SNP C352T apenas nos machos $(\mathrm{P}=0,0165)$, associados a um efeito aditivo de 0,58 gramas a cada alelo T adicionado ao genótipo (Figura 21b). O rendimento de carcaça dos machos com genótipo TT foi aproximadamente 2,55\% maior que fêmeas de genótipo TT. O alelo T tem origem na linhagem de corte, que foi selecionada para maior rendimento de carcaça. Para os genótipos CC e CT, o rendimento de carcaça foi semelhante nas fêmeas e nos machos. A diferença enontrada entre machos e fêmeas para o genótipo TT parece estar relacionada com o rendimento de peito, cujo alelo T apresentou um efeito aditivo de 0,450 gramas no rendimento de peito dos machos. 


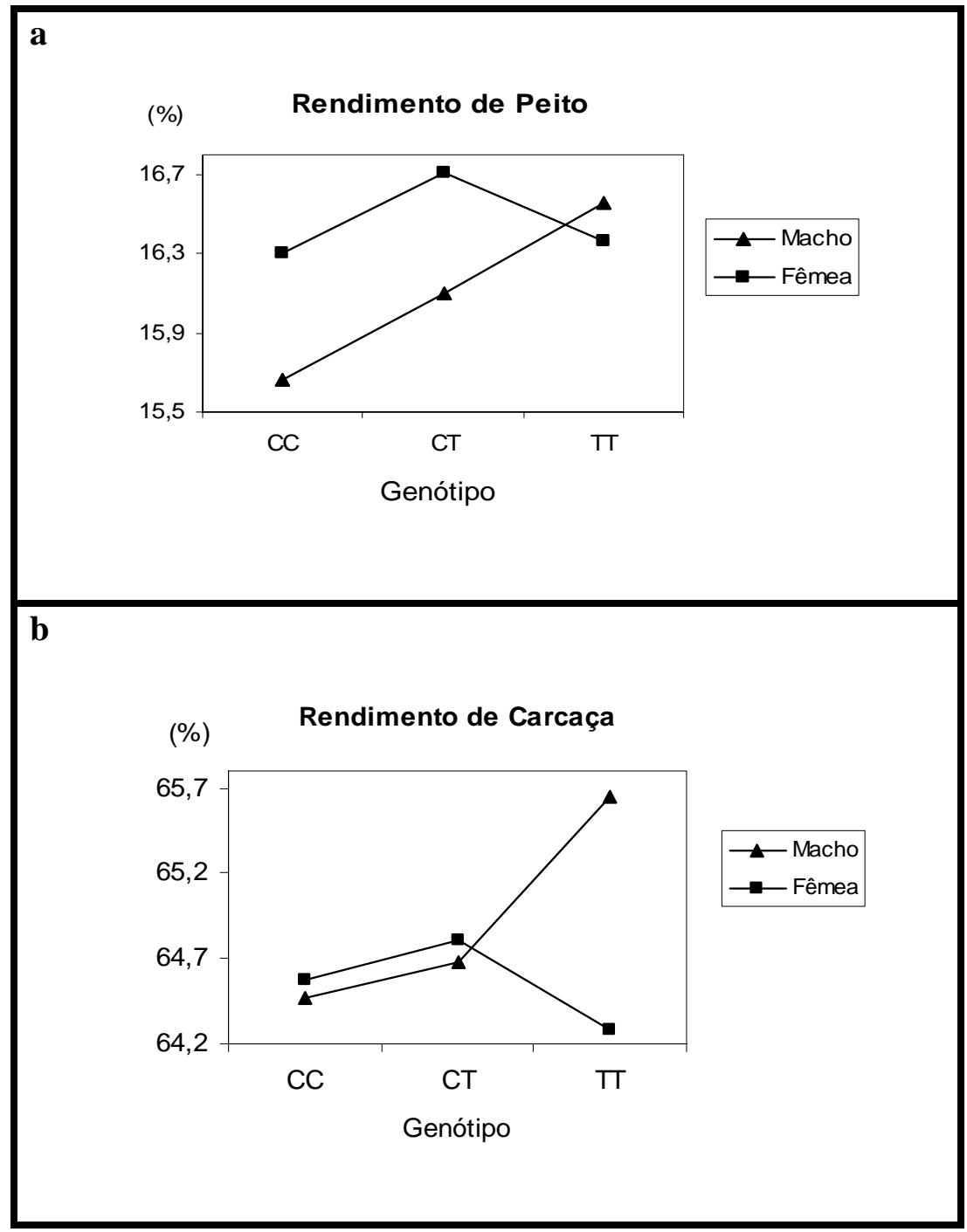

Figura 21 - (a) Médias estimadas para rendimento de peito (RPEIT) e (b) para rendimento de carcaça (RCARC) para aves F2 TCTC de acordo com a interação entre sexo e genótipo do SNP C352T

No presente trabalho, foi verificado efeito significativo da interação genótipo e sexo com gramas de proteína bruta $(\mathrm{P}=0,0112)$ e com gramas de cinza $(\mathrm{P}=0,0150)$ na carcaça, evidenciando um comportamento diferenciado do genótipo entre machos e fêmeas (Figura 22). De modo geral, os macjos apresentaram mais gramas de PB e de CZ do que fêmeas. Isso se justifica pelo fato de machos serem mais pesados do que fêmeas e também machos apresentam uma estrutura óssea mais pesada. Os genótipos apresentaram diferenças significativas em gramas de proteína bruta somente nos machos, associados a um efeito aditivo de 9,9 gramas a cada alelo T adicionado ao genótipo (Figura 22a). Para gramas de cinza na carcaça os genótipos apresentaram 
diferenças significativas somente nos machos, associados a um efeito aditivo de 1,7 gramas a cada alelo mutante $\mathrm{T}$ adicionado ao genótipo (Figura 22b). Esses resultados mostram que o alelo T está ligado a um maior peso de proteína bruta e cinza na carcaça de machos, o que pode ser explicado pelo fato do alelo $\mathrm{T}$ ter origem da linhagem de corte. A diferença na expressão desse genótipo entre machos e fêmeas pode ser devido a influência de outros genes presentes nos comossomos sexuais.

As aves utilizadas no presente trabalho foram criadas como frangos de corte e submetidos ao mesmo manejo e nutrição. Segundo Leeson (1995), a deposição de proteína na carcaça é pré-estabelecida pela genética da ave. Independente da ingestão ocorre limite de deposição diário, que não pode ser compensado, entretanto, as variações ocorridas no total de deposição de proteína podem ser devido à nutrição. O teor de proteína bruta e de aminoácidos essenciais de uma dieta influencia a composição da carcaça de frangos, o alto teor de proteína bruta promove aumento no teor de proteína e reduz o teor de gordura na carcaça. 


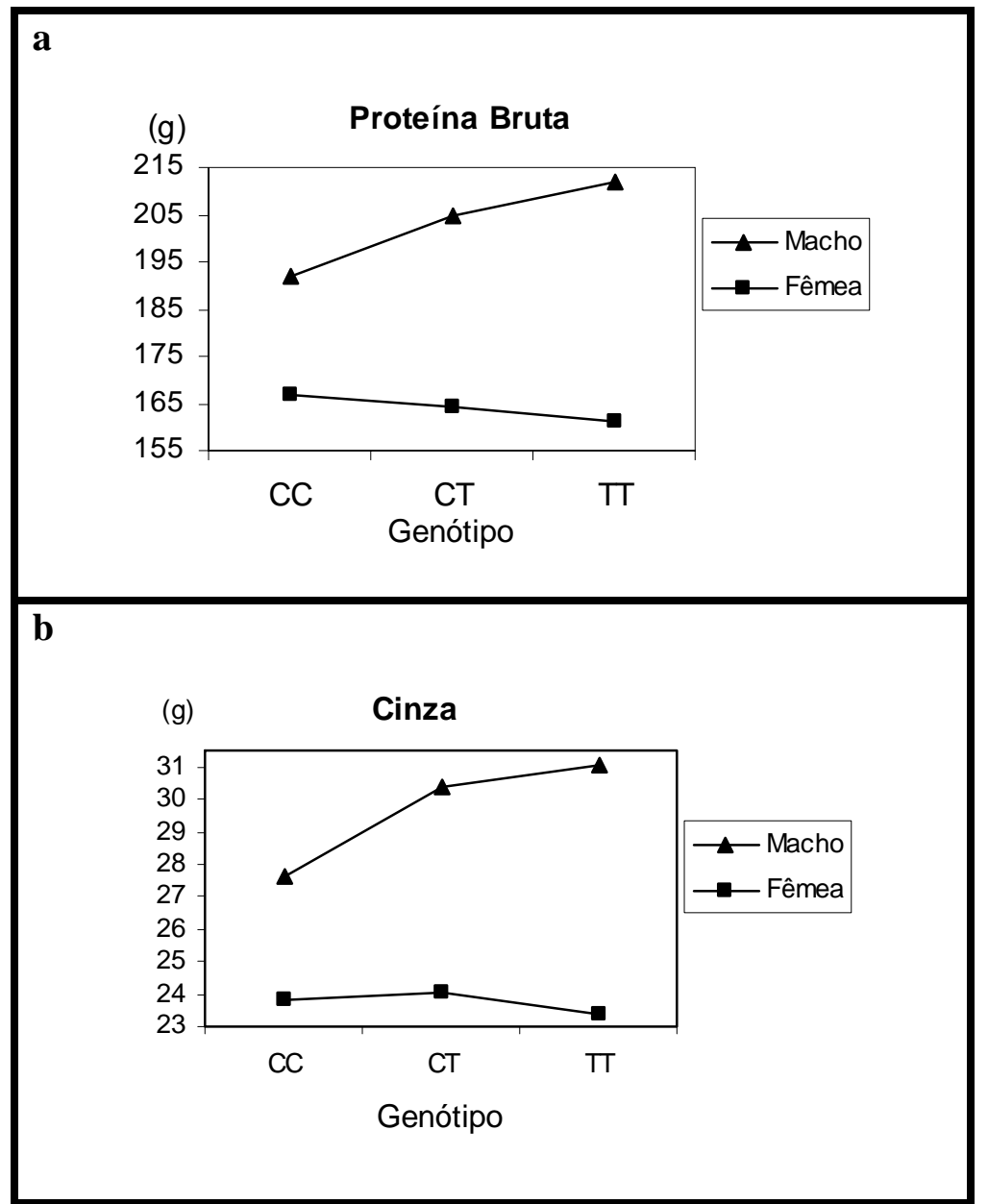

Figura 22 - (a) Médias estimadas para proteína bruta e (b) cinza na carcaça para aves F2 da populacão TCTC, de acordo com os genotipos CC, CT e TT do SNP C352T

\subsubsection{Associações para o SNP G915A}

Os genótipos do SNP G915A apresentaram diferença significativa para consumo de ração ( $\mathrm{P}=0,0339)$. Animais com o genótipo AA tiveram consumo de ração maior em relação aos genótipos GG e GA, havendo um efeito aditivo significativo neste loco (Figura 23a). O alelo A tem origem na linhagem de postura, para cada alelo A adicionado houve um aumento de aproximadamente 29 gramas no consumo de ração, porém, esperava-se que este alelo estivesse ligado a uma diminuição do consumo de alimento.

A partir desse resultado, pode-se sugerir duas hipóteses: 1) que no período avaliado as aves de postura estariam em uma fase do desenvolvimento diferente das aves de corte e consumindo mais alimento; 2) uma vez que esse SNP não está associado ao peso corporal, a 
associação encontrada com o consumo de alimento pode ter sido devido ao desequilíbrio de ligação na população F2 e estar ligado a outro gene localizado nas proximidades do gene do receptor da leptina. Mesmo que a diferença de consumo tenha sido atribuída a esse SNP, muitos outros genes podem estar atuando nessa característica. Além disso, é importante considerar o fator idade e também os níveis de leptina nesses animais. Cassy et al. (2004) estudaram o efeito da leptina na regulação do consumo de alimento em aves de corte e de postura. Tais autores sugerem que a ação da leptina no consumo de alimento em aves é dependente da idade e que aves de corte podem ser menos sensíveis a leptina do que as aves de postura.

$\mathrm{O}$ rendimento de pulmão foi influenciado significativamente $(\mathrm{P}=0,0287)$ pelo genótipo do SNP G915A. Animais com o genótipo GG e GA apresentaram rendimento de pulmão semelhante, porém maior que o genótipo AA (Figura 23c). O alelo G apresenta um efeito de dominância sobre o alelo A. Com base nesses resultados foi possível verificar que o alelo G proveniente da linhagem de corte está relacionado a um maior peso do pulmão em relação ao peso corporal.

Para rendimento de coxas e sobrecoxas o genótipo do SNP G915A também foi significativo $(\mathrm{P}=0,0287)$. Animais com o genótipo homozigoto GG e AA apresentaram rendimento de coxas e sobrecoxas semelhantes, porém superior em relação ao genótipo GA, havendo um efeito negativo de sobredominância significativo neste loco (Figura 23b). O alelo G vem da linhagem de corte e o alelo A da linhagem de postura. Quando em heterozigose a combinação destes alelos foi associada a um RCOXA inferior aos homozigotos. O rendimento de coxa e sobrecoxa são características de grande valor econômico, pois fazem parte da lista dos cortes nobres do frango. 


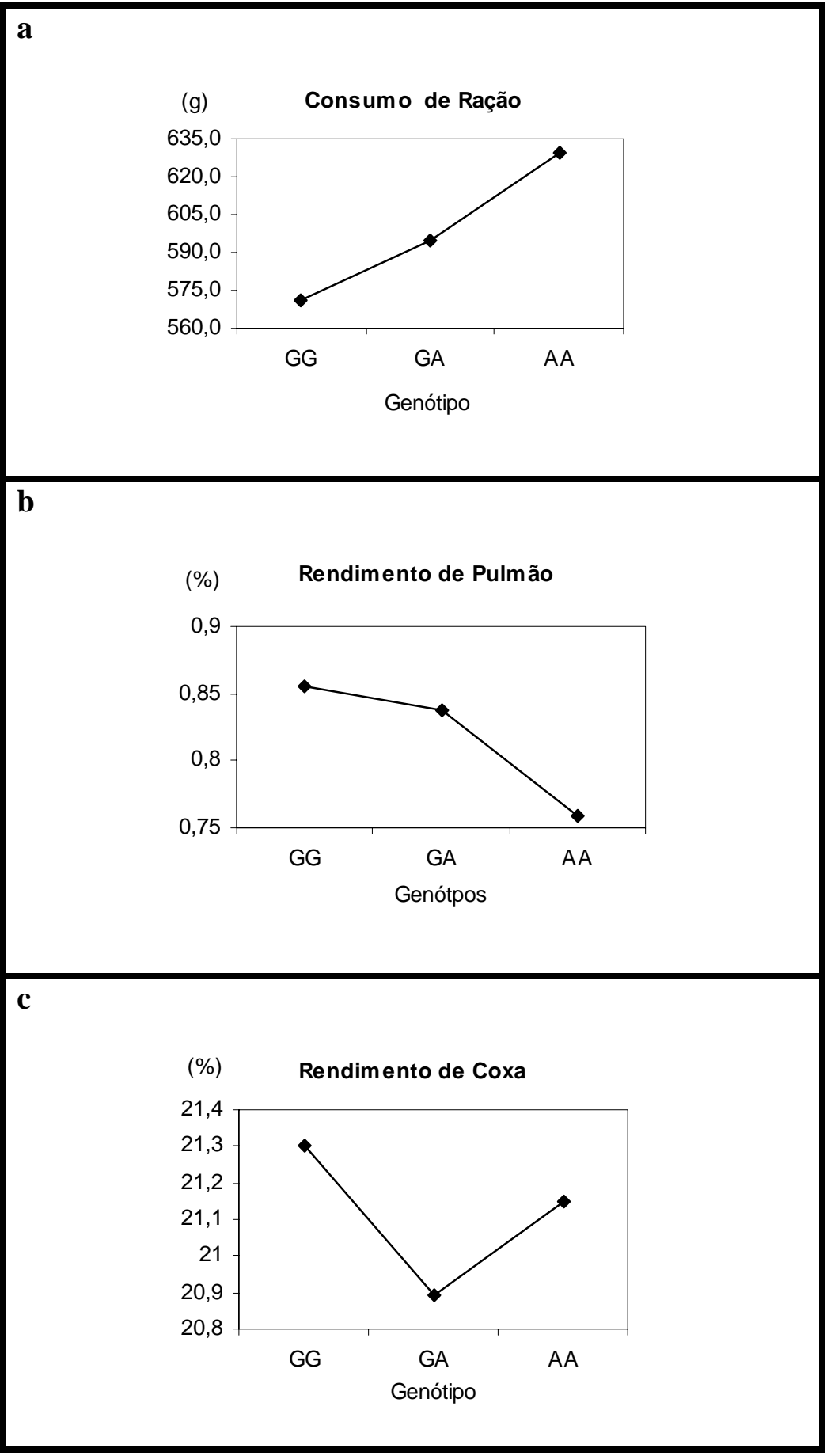

Figura 23 - (a) Médias estimadas para consumo de ração, (b) rendimento de pulmão e (c) rendimento de coxas e sobrecoxas para aves F2 da populacão TCTC, de acordo com os genotipos GG, GA e AA do SNP G915A 


\subsection{Efeito de polimorfismos no gene do receptor da leptina}

O estudo do gene do receptor da leptina em animais domésticos tem crescido nos últimos anos, a maioria busca por polimorfismos que sejam associados a características relacionadas à gordura. Em suínos, polimorfismos no gene do receptor da leptina foram associados a ganho de peso, eficiência alimentar e espessura de gordura (CHEN; CHANG; SU, 2004), já em bovinos polimorfismos nesse gene foram associados ao balanço energético e rendimento de proteína (LIEFERS et al., 2005).

Associações de polimorfismos no gene do receptor da leptina de galinhas com características relacionadas à deposição de gordura foram relatadas por Kuo et al. (2002) e Wang et al. (2004). No presente trabalho essa associação não foi encontrada, entretanto, polimorfismos foram associados a características de desempenho e rendimento de carcaça as quais apresentam um importante papel nos programas de melhoramento genético.

Na geração F2 estudada, o alelo A do SNP G915A provém da linhagem de postura e o alelo $G$ da linhagem de corte. $O$ alelo A foi associado ao maior consumo de ração, o alelo $G$ ao maior rendimento de pulmão e os alelos A e $G$ em homozigose foram associados ao maior rendimento de coxas e sobrecoxas.

No SNP C352T, o alelo T provém da linhagem de corte enquanto que o alelo C provém da linhagem de postura. Na geração F2, machos com o alelo T apresentaram maior rendimento de carcaça, rendimento de peito, gramas de proteína bruta e cinza quando comparados a machos com o alelo C. Com nesses resultados pode-se inferir que este alelo está ligado a um efeito específico no crescimento do tecido muscular de machos, com aumento no peso do peito que resulta em maior rendimento de carcaça. Animais com o alelo $\mathrm{C}$ tiveram rendimento de fígado maior do que animais com o alelo $\mathrm{T}$.

Por ocorrerem em região de íntron, provavelmente esses SNPs não estão envolvidos diretamente com as características associadas, mas podem estar ligados a outra mutação localizada na região regulatória do gene do receptor da leptina (KUO et al., 2002) ou próximo a ele. No futuro outros polimorfismos deverão ser explorados em regiões codificadoras deste gene, para serem utilizados como marcadores associados a características de desempenho e carcaça em aves.

Em adição, o gene do receptor da leptina pode não ser o gene que realmente esteja causando a diferença nas características estudadas. Segundo Rothschild e Soller (1999), sempre 
haverá a possibilidade de que o gene estudado não seja o que realmente esteja causando a diferença na característica, mas que esteja somente ligado ao QTL. Em geral, características quantitativas são afetadas por grande número de genes, onde cada um deles apresenta efeito individual relativamente pequeno.

\subsection{Localização do gene do receptor da leptina no mapa de ligação da Embrapa}

O mapa de ligação foi construído pelo método da máxima verossimilhança, com o auxílio do programa CRIMAP (GREEN et al., 1990), A partir dos dados disponíveis construímos o mapa de ligação do cromossomo 8 com auxílio do programa CRIMAP (GREEN et al., 1990) e MapChart - versão 2,1 (VOORRIPS, 2002). A média da distância entre os marcadores do mapa GG8 (Embrapa) foi 18,56 cM e a extensão do mapa foi 92,8 cM (Figura 24). O mapa GG8 foi semelhante ao mapa consenso e a ordem dos marcadores foi a mesma. No mapa GG8 o marcador RLEP está localizado na posição 92,8 cM assemelhando-se a localização do gene do receptor da leptina no mapa consenso disponível no NCBI (http://www.ncbi.nlm.nih.gov/mapview/), onde o gene está localizado entre os marcadores LEI0044 e MCW0351 nas posicões de 96 cM e 105 cM respectivamente.

A localização deste gene no mapa da população da Embrapa possibilita que os SNPs identificados neste estudo sejam utilizados como marcadores na análise de QTLs no GGA8. 


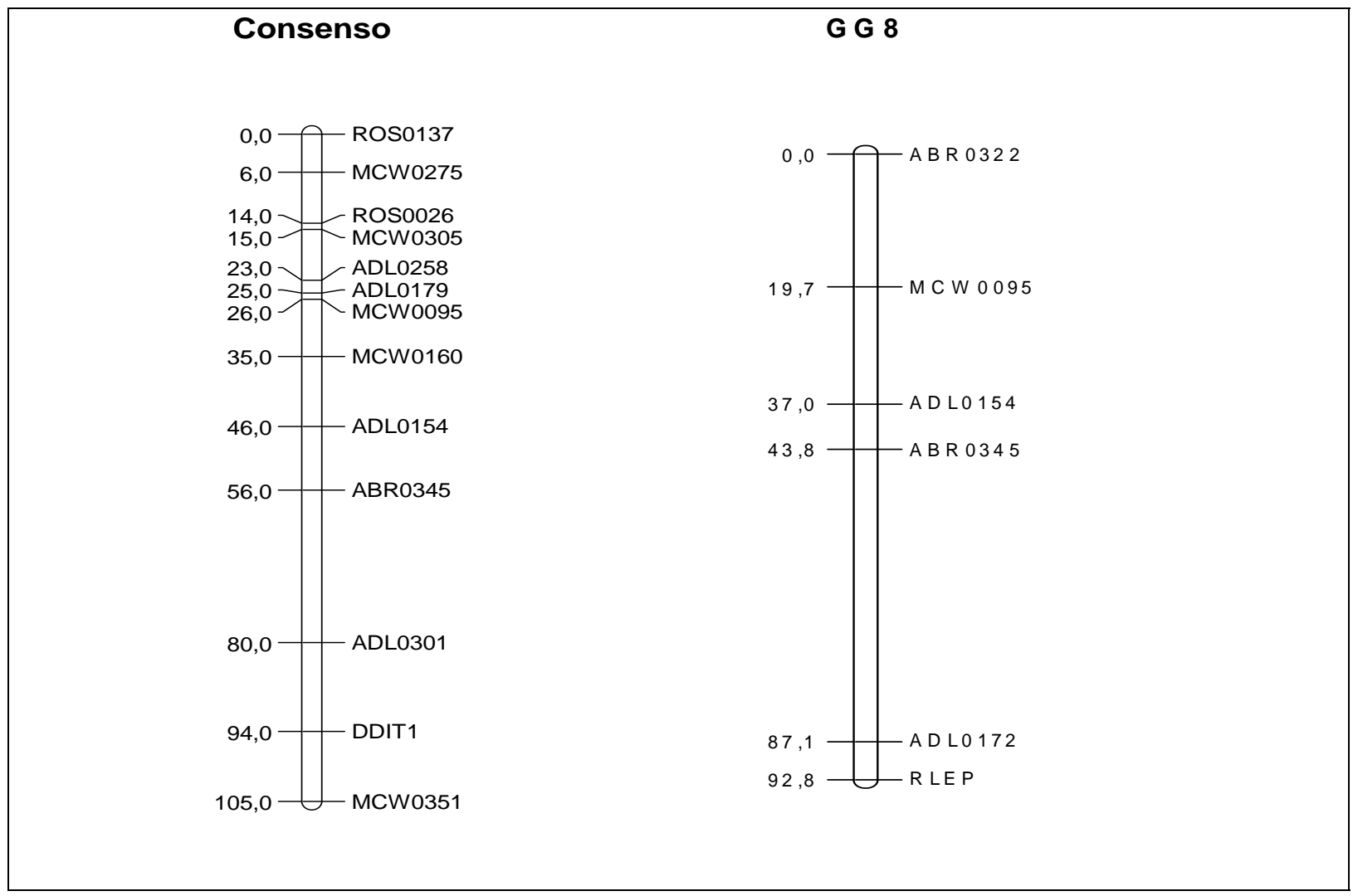

Figura 24 - Mapas de ligação consenso (Schmid, 2000) e GG8 da Embrapa contendo as posições dos marcdores em cM (kosambi). Desenhados com o auxílio do programa Mapchart (Voorrips, 2002)

\subsection{QTLs mapeados no cromossomo 8 de Gallus gallus}

No cromossomo 8, Tuiskula-Haavisto et al. (2002) em experimento empregando uma população desenvolvida a partir de linhagens de poedeiras, encontraram QTL para número de ovos entre os marcadores MCW100 e MCW345 a 34 e 58 cM, respectivamente.

Sewalem et al. (2002) genotiparam 466 aves distribuídas em 30 familias F2 de uma população desenvolvida a partir de linhagem de corte comercial e linhagem de postura e mapearam QTLs significativos para peso corporal a três e seis semana de idade, a 68 cM e 34 cM entre os marcadores ADL0179 e ROS075. Ikeobi et al. (2004) utilizaram a mesma população empregada por Sewalem et al. (2002) onde mapearam quatro QTLs entre os marcadores ADL79 e ROS075: QTL para músculo do peito (covariável carcaça) a 0 cM; asa (covariável carcaça) a 42 cM; músculo do peito (covariável músculo da coxa e sobrecoxa) a 38 cM; e músculo da coxa (covariável músculo da sobrecoxa) a 52 cM. 
Rabie et al. (2005) estudaram uma população gerada a partir do cruzamento de duas linhagens comerciais divergentes de frango de corte com o objetivo de estudar QTLs que controlam características relacionadas a ascite, encontraram QTLs sugestivos entre os marcadores ADL301 e LEI044 para peso corporal a 101 cM, coloração do peito a 80 cM e peso do ventrículo a 105 cM.

Moura et al. (2006) utilizaram a mesma população deste estudo e encontraram QTL sugestivo para peso da moela a 62 cM entre os marcadores ABR345 e ADL172.

O gene do receptor da leptina esta localizado na porção final do cromossomo 8 entre os marcadores LEI0044 (96cM) e MCW0351 (105cM). Nesta região existem poucos marcadores mapeados e na literatura buscada não foram descritos QTLs entre esses marcadores. 


\section{CONCLUSÕES}

- Não foi possível amplificar o gene da leptina para estudos de polimorfismos.

- No íntron 8 do gene do receptor da leptina ocorreram seis SNPs com maior freqüência. O SNP C352T foi associado a características de rendimento e carcaça.

- No íntron 19 do gene do receptor da leptina foram identificados cinco SNPs e uma inserção/deleção. O SNP G915A foi associado a características de rendimento e carcaça.

- $\quad$ gene do receptor da leptina foi localizado no mapa de ligação do cromossomo 8 da Embrapa. O próximo passo será realizar a análise de QTL incluindo esses SNPs como marcadores. 


\section{REFERÊNCIAS}

ANDERSON, L.; HALEY, C. S.; ELLEGREN, H.; KNOTT, S.A.; JOHANSSON, M.; ANDERSON, K.; ANDERSON-EKLUND, L.; EDFORS-LILJA, I.; FREDHOLM, M.; HANSSON, I.; HAKANSSON, J.; LUNDSTROM, K. Genetic mapping of quantitative trait loci for growth and fatness in pigs. Science, Washington, v. 263, p. 1771-1774, 1994.

ASSOCIAÇÃO BRASILEIRA DOS EXPORTADORES DE FRANGO. Relatório Anual 2005. São Paulo, 2006. 54 p.

BADO, A.; LEVASSEUR, S.; ATTOUB, S.; KERMORGANT, S.; LAIGNEAU, J. P.; BORTOLUZZI, M. N.; MOIZO, L.; LEHY, T.; GUERRE-MILLO, M.; LE MARCHANDBRUSTEL, Y.; LEWIN, M. J. The stomach is a source of leptin. Nature, London, v. 394, p.790793, 1998.

BARON, E. E.; RUY, D. C.; NONES, K.; LEDUR, M. C.; CAMPOS, R. L. R.; AMBO, M.; COUTINHO, L. L. Identificação de QTL para peso corporal em aves (Gallus gallus) no cromossomo 4. In: CONGRESSO NACIONAL DE GENÉTICA 49., 2003, Águas de Lindóia. Resumos...Ribeirão Preto: Sociedade Brasileira de Genética, 2003. 1CD-ROM.

BENNETT, A. K.; HESTER, P. Y.; SPURLOCK, D. E. Polymorphisms in vitamin D receptor, osteopontin, insulin-like growth factor and insulin, and their associations with bone, egg and growth traits in a layer-broiler cross in chickens. Animal Genetics, Oxford, v. 37, n. 3, p. 283286, 2006.

BENOMAR, V.; RIDEAU, N.; CROCHET, S.; DEROUET, M.; TAOUIS, M. Leptin fully suppresses acethylcholine-induced insulin secretion and is reversed by tolbutamide in isolated perfused chicken pancreas. Hormone and Metabolic Research, Stuttgard, v. 35, p. 81- 85, 2003.

BOTSTEIN D, RISCH N. Discovering genotypes underlying human phenotypes: past successes for mendelian disease, future approaches for complex disease. Nature Genetics, London, v. 33, p. 228-237, 2003.

BROOKES, A. J. The essence of SNP. Gene, Amsterdam, v.234, p. 177-186, 1999.

BRYNE, P.F.M.D.; MC. MULLEN. Defining genes for agricultural traits: QTL analysis and the candidate gene approach. Probe, Ontario, v. 7, p. 24-27, 1996. 
BUCHANAN, F. C.; FITZSIMMONS, C. J.; VAN KESSEL, A. G.; THUE, T. D.;

WINKELMAN-SIM, D. C.; SCHMUTZ, S. M. Association of a missense mutation in the bovine leptin gene with carcass fat content and leptin mRNA levels. Genetics Selection Evolution, Paris, v. 34, n. 1, p. 105-116, 2002.

BURT, D. W. Applications of biotechnology in the poultry industry. World's Poultry Science Journal, Ithaca, v.58, p.5-13, 2002.

BURT D.W.; HOCKING, P. M. Mapping quantitative trait loci and identification of genes that control fatness in poultry. Proceedings of the Nutrition Society, London, v. 61, n. 4, p. 441-446, 2002.

BURT, D. W. Chicken genome: current status and future opportunities. Genome Research, Cold Spring Harbor, v.12, p. 1692-1698, 2005.

CARO, J. R.; SINHÁ, M. K.; KOLACZYNSKI, J. W.; ZHANG, P. L.; CONSIDINE, R. V. Leptin: The tale of na obese gene. Diabetologia, Heidelberg, v. 45, p. 1455-1462, 1996.

CARRE, W.; WANG, X.; PORTER, T.E.; NYS, Y.; TANG, J.; BERNBER,G. E.; MORGAN, R.; BURNSIDE, J.; AGGREY, S.E.; SIMON, J.; COGBURN, L.A.; Chicken genomics resource: sequencing and annotation of 35,407 ESTs from single and multiple tissue cDNA libraries and CAP3 assembly of a chicken gene index. Physiological Genomics, Rockville, v. 16, n. 25, p. 514-524, 2006.

CASSY, S.; PICARD, M.; CROCHET, S.; DEROUET, M.; KEISLER, D.H.; TAOUIS, M. Peripheral leptin effect on food intake in young chickens is influenced by age and strain.

Domestic Animal Endocrinology, Aubur, v. 27, n. 1, p.51-61, 2004.

CHEN, C.C.; CHANG, T.; SU, H.Y. Characterization of porcine leptin receptor polymorphisms and their association with reproduction and production traits. Animal Biotechnology, Lippincott. v.15, n. 1, p.89-102, 2004.

CHEN, H.; CHARLAT, O.; TARTAGLIA L.A.; WOOLF, E. A.; WENG, X.; ELLIS, S. J. Evidence that the diabetes gene encodes the leptin receptor: Identification of a mutation in the leptin receptor gene in db/db mice. Cell, Cambridge, v. 84, p. 491-495, 1996.

CHEHAB, F. F.; LIM, M. E.; LU, R. Correction of the sterility defect in homozygous obese female mice by treatment with the human recombinant leptin. Nature Genetics, New York, v. 12, p. 318-320, 1996. 
COLEMAN, D. L. Effects of parabiosis of obese with diabetes and normal mice. Diabetologia, Heidelberg, v. 9, p. 294-298, 1973.

CORPET, F. Multiple sequence alignment with hierarchical clustering. Nucleic Acids Research, London, v. 16, n. 22, p. 10881-10890, 1988.

CUMIN, F.; BAUM, H. P.; LEVENS, N. Leptin is cleared from the circulation primarily by the kidney. International Journal of Obesity, London, v.20, p.1120-1126, 1996.

DOYON, C.; DROUIN, G.; TRUDEAU, V.L.; MOON, T.W. Molecular evolution of leptin. General and Comparative Endocrinology, Stuttgard, v. 124, n. 2 p. 188-198, 2001.

DRIDI, S.; BUYSE, J.; DECUYPERE, E.; TAOUIS, M. Potential role of leptin in increase of fatty acid synthase gene expression in chicken liver. Domestic Animal Endocrinology, Aubur, v. 29, p. 646-660, 2005.

DUNN, I.C.; BOSWELL, T.; FRIEDMAN-EINAT, M.; ESHDAT, Y.; BURT, D.; PATON, I.R. Mapping of the leptin receptor gene (LEPR) to chicken chromosome 8. Animal Genetics, Oxford, v. 31, p. 290, 2000.

EWING, B.; GREEN, P. Base-calling of automated sequencer traces using Phred. II, Error probabilities. Genome Research, Woodbury, v. 8, p.186-194, 1998.

FIGUEIREDO, E.A.P.; ROSA, P.S.; SCHEUERMANN, G.N.; JAENISCH, F.R.F.; SCHMIDT, G.S.; LEDUR, M.; BRENTANO, L.; COSTA, C.A.F. Genetic gain in body weight feed conversion and carcass traits in White Plymouth Rock broiler strain Embrapa 021. In: WORLD CONFERENCE ON ANIMAL PRODUCTION, 9.; REUNIÃO DA ASSOC.

LATINOAMERICANA DE PRODUÇÃO ANIMAL, 18., Proceedings...Porto Alegre: WAAP; ALPA; SBZ; UFRGS, 2003a. 1 CD-ROM.

FIGUEIREDO, E.A.P.; SCHMIDT, G.S.; LEDUR, M.C.; AVILA, V.S.; BRUM, P.A.R.; FIORENTIN, L.; JAENISCH, F.R.F. Genetic gain in egg production and egg weight in White Leghorn Embrapa 011. In: WORLD CONFERENCE ON ANIMAL PRODUCTION, 9.; REUNIÃO DA ASSOC. LATINOAMERICANA DE PRODUÇÃO ANIMAL, 18., Proceedings...Porto Alegre: WAAP; ALPA; SBZ; UFRGS, 2003b. 1 CD-ROM. 
FREDERICH, R.C.; HAMANN, A.; ANDERSON, S.; LÖLLMANN B.; LOWELL, B.B.; FLIER J. Leptin levels reflect body lipid content in mice: evidence for diet-induced resistance to leptin action. Nature Medicine, New York, v.1, p. 1311-1314, 1995.

FRIEDMAN-EINAT, M. T.; BOSWELL, G.; HOREV, G.; GIRISHVARMA, I. C.; DUNN TALBOT, R.T.; SHARP, P.J.The chicken leptin gene: Has it been cloned? General and Comparative Endocrinology, New York, v. 115, p. 354-363, 1999.

FRIEDMANN, J.M.; HALAAS, J.L. Leptin and the regulation of body weight in mammals. Nature, London, v. 395, p.763-770, 1998.

GORDON, D.; ABAJIAN, C.; GREEN, P. Consed: A graphical tool for sequence finishing. Genome Research, Cold Spring Harbor, v. 8. p.195 - 202. 1998.

GREEN, P.; FALLS, K.; CROOKS, S. CRI-MAP Program version 2.4. St Louis: Washington University School of Medicine, 1990.

GROBET, L.; MARTIN, L. J.; PONCELET, D.; PIROTTIN, D.; BROUWERS, B.; RIQUET, J.; SCHOEBERLEIN, A.; DUNNER, S.; MENISSIER, F.; MASSABANDA, J.; FRIES, R.; HANSET, R.. GEORGES, M. A deletion in the bovine myostatin gene causes the double-muscled phenotype in cattle. Nature Genetics, New York, v. 17, p. 71-74, 1997.

GROENEN, M.A.M.; CHENG, H.H.; BUMSTEAD, N.; BENKEL, B.F.; BRILES, W.E.; BURKE, T.; BURT, D.W.; CRITTENDEN, L.B.; DODGSON, J.; HILLEL, J.; LAMONT, S.; PONCE DE LEON, F.A.; SOLLER, M.; TAKAHASHI, H.; VIGNAL, A. A consensus linkage map of the chicken genome. Genome Research, Woodbury, v.10, p. 137-147. 2000.

GUIMARÃES, P. E. M.; COSTA, M. C. R. SNPs: Sutis diferenças de um código. Biotecnologia Ciência \& Desenvolvimento, Brasília, v. 26, p.24-27, 2002.

HARDGE, T.; KÖPKE, K.; WIMMERS, K.; LEUTHOLD, G. Association between polymorphism of the leptin-gene (LEP) and performance traits in a porcine ressource family and in commercial outbred populations. INTERNATIONAL CONFERENCE ON ANIMAL GENETICS, 26., Auckland, New Zealand, 1998. p. 9-14.

HE, Y.; CHEN, H.; QUON, M. J.; REITMAN, M. The Mouse obese Gene. Journal of Biological Chemistry, New York, v.270, n. 48, p. 28887-28891 
HERVEY, G. The effects of lesions in the hypothalamus in parabiotic rats. Journal of Physiology, Stanford, v.145, p.336-352, 1959.

HILLIER, L.W.; MILLER, W.; BIRNEY, E.; WARREN, W.; HARDISON, R. C.; PONTING C.P.; BORK, P.; BURT, D. W.; GROENEN, M. A.; DELANY, M. E.; DODGSON, J. B.; CHINWALLA, A. T.; CLIFTEN, P. F.; CLIFTON, S. W.; DELEHAUNTY, K. D.; FRONICK, C.; FULTON, R. S; GRAVES, T. A.; KREMITZKI, C.; LAYMAN, D.; MAGRINI, V.; MCPHERSON, J. D.; MINER, T. L.; MINX, P.; NASH, W. E.; NHAN, M. N.; NELSON, J. O.; ODDY, L.G.; POHL, C. S.; RANDALL-MAHER, J.; SMITH, S. M.; WALLIS, J. W.; YANG, S. P.; ROMANOV, M. N.; RONDELLI, C. M.; PATON, B.; SMITH, J.; MORRICE, D.; DANIELS, L.; TEMPEST, H. G.; ROBERTSON, L.; MASABANDA, J. S.; GRIFFIN, D. K.; VIGNAL, A.; FILLON, V.; JACOBBSON, L.; KERJE, S.; ANDERSSON, L.; CROOIJMANS, R. P.; AERTS, J.; VAN DER POEL, J. J.; ELLEGREN, H.; CALDWELL, R. B.; HUBBARD, S. J.; GRAFHAM, D. V.; KIERZEK, A. M.; MCLAREN, S. R.; OVERTON, I. M.; ARAKAWA, H.; BEATTIE, K. J.; BEZZUBOV, Y.; BOARDMAN, P. E.; BONFIELD, J. K.; CRONING, M. D.; DAVIES, R. M.; FRANCIS, M. D.; HUMPHRAY, S. J.; SCOTT, C. E.; TAYLOR, R. G.; TICKLE, C.; BROWN, W. R.; ROGERS, J.; BUERSTEDDE, J. M.; WILSON, S. A.; STUBBS, L.; OVCHARENKO, I.; GORDON, L.; LUCAS, S.; MILLER, M. M.; INOKO, H.; SHIINA, T.; KAUFMAN, J.; SALOMONSEN, J.; SKJOEDT, K.; WONG, G. K.; WANG, J.; LIU, B.; WANG, J.; YU, J.; YAN,G. H.; NEFEDOV, M.; KORIABINE, M.; DEJONG, P. J.; GOODSTADT, L.; WEBBER, C.; DICKENS, N. J.; LETUNIC, I.; SUYAMA, M.; TORRENTS, D.; VON MERING, C.; ZDOBNOV, E. M.; MAKOVA, K.; NEKRUTENKO, A.; ELNITSKI, L.; ESWARA, P.; KING, D. C.; YANG, S.; TYEKUCHEVA, S.; RADAKRISHNAN, A.; HARRIS RS, CHIAROMONTE F, TAYLOR J, HE J, RIJNKELS M, GRIFFITHS-JONES S, URETAVIDAL, A.; HOFFMAN, M. M.; SEVERIN, J.; SEARLE, S. M.; LAW, A. S.; SPEED, D.; WADDINGTON, D.; CHENG, Z.; TUZUN, E.; EICHLER, E.; BAO, Z.; FLICEK, P.; SHTEYNBER,G. D.D.; BRENT, M. R.; BYE, J. M.; HUCKLE, E. J.; CHATTERJI, S.; DEWEY, C.; PACHTER, L.; KOURANOV, A.; MOURELATOS, Z.; HATZIGEORGIOU, A. G.; PATERSON, A. H.; IVARIE, R.; BRANDSTROM, M.; AXELSSON, E.; BACKSTROM, N.; BERLIN, S.; WEBSTER, M. T.; POURQUIE, O.; REYMOND, A.; UCLA, C.; ANTONARAKIS, S. E.; LONG, M.; EMERSON, J. J.; BETRAN, E.; DUPANLOUP, I.; KAESSMANN, H.; HINRICHS, A. S.; BEJERANO, G.; FUREY, T. S.; HARTE, R. A.; RANEY, B.; SIEPEL, A.; KENT, W. J.; HAUSSLER, D.; EYRAS, E.; CASTELO, R.; ABRIL, J. F.; CASTELLANO, S.; CAMARA, F.; PARRA, G.; GUIGO, R.; BOURQUE, G.; TESLER, G.; PEVZNER, P.A.; SMIT, A.; FULTON, L. A.; MARDIS, E. R.; WILSON RK; INTERNATIONAL CHICKEN GENOME SEQUENCING CONSORTIUM. Sequence and comparative analysis of the chicken genome provide unique perspectives on vertebrate evolution. Nature, London, v. 432, n. 7018, p. 695-716, Dec. 2004.

HOREV, G.; EINANT, P.; AHARONI, T.; ESHDAT, Y.; AND FRIEDMAN-EINAT, M. Molecular cloning and properties of the chicken leptin receptor (CLEPR) gene. Molecular and Cellular Endocrinology, Amsterdam, v.162, p. 95-106, 2000. 
JALVIN, G. R.; VAN'T SLOT, R.; VAN OOST, B.A; Chicken single nucleotide polymorphism identification and selection for genetic mapping. Poultry Science, Ithaca, v. 83, n. 12, p. 1925-1931, 2004.

KENNEDY, G.C. The Role of Depot Fat in the Hypothalamic Control of Food Intake in the Rat Proceedings of the Royal Society of London, London, v. 140, n. 901, p. 578-592, 1953.

KIM, H.; SCHMIDT, C.J.; DECKER, K.S.; EMARA, M.G. A double-screening method to identify reliable candidate non-synonymous SNPs from chicken EST data. Animal Genetics, Oxford, v.34, p.249-254, 2003.

KLEIN, C.H.; LIMA, G.M.M.; LEDUR, M.C.; SUZIN, L. Espectroscopia infravermelho próxima para predição da composição de carcaça de frangos de corte. Revista Brasileira de Ciência Avícola, Campinas, Supl. 5, p. 108, 2003.

KUO, A. Y.; ASHWELL, C. M.; DENBOW, C. J.; SIEGEL, P. B.; DENBOW, D. M. Identification of a single nucleotide polymorphism in the leptin receptor gene of chicken lines divergently selected for body weight. Poultry Science, Ithaca, Supl. 1, p. 179, 2002.

KUO, A.Y; CLINE, M. A.; WERNER, E.; SIEGEL, P. B.; DENBOW, D. M. Leptin effects on food and water intake in lines of chickens selected for high or low body weight. Physiology \& Behavior, New York, v. 84, n. 3, p. 459-464, 2005.

LEDUR, M.C. Genoma do frango - Mapeamento de QTL. In: REUNIÃO ANUAL DA SOCIEDADE BRASILEIRA DE ZOOTECNIA, 38., 2001, Piracicaba, SP. Anais... Viçosa: Sociedade Brasileira de Zootecnia, 2001. p. 620-633.

LEDUR, M.C.; BERTANI, G.R. Análise genômica na avicultura: Resultados e perspectivas. In: SIMPÓSIO NACIONAL DE MELHORAMENTO ANIMAL 4., 2002. Anais...Campo Grande,MS, 2002. p. 132-141

LEESON, S. Nutrição e qualidade de carcaça de frangos de corte. In: COFERÊNCIA APINCO DE CIÊNCIA E TECNOLOGIA AVÍCOLAS, 1995, Curitiba. Anais... Campinas: FACTA, 1995. p.111-118.

LEWIN, B. Genes VII. Oxfor: Oxford University Press, 2000. 955 p. 
LICINIO, J.; NEGRAO, A. B.; MANTZOROS, C.; KAKLAMANI, V.; WONG, M.L.; BONGIORNO, P.B.; MULLA, A.; CEARNAL, L.; VELDHUIS, J.D.; FLIER, J.S., MCCANN, S.M.; GOLD, P.W. Synchronicity of frequently sampled, 24-h concentrations of circulating leptin, luteinizing hormone, and estradiol in healthy women. Proceedings of the National Academy of Sciences, Washington, v. 95, p. 2541-2546, 1998.

LIEFERS, S.C.; VEERKAMP, R.F.; TE PAS, M.F.; DELAVAUD C, CHILLIARD Y, PLATJE M, VAN DER LENDE T. Leptin promoter mutations affect leptin levels and performance traits in dairy cows. Animal Genetics, Oxford, v.36, n.2, p.111-118, 2005.

MAFFEI, M.; HALAAS, J.; RAVUSSIN, E.; PRATLEY, R.E.; LEE, G.H.; ZHANG, Y.; FEI, H.; KIM, S.; LALLONE, R.; RANGANATHAN, S.; KERN, P.A.; FRIEDMAN, J.M.. Leptin levels in human and rodent: measurement of plasma leptin and ob RNA in obese and weight-reduced subjects. Nature Medicine, New York, v.1, n.11, p. 1155-1161, 1995.

MASUZAKI, H.; OGAWA, Y.; SAGAWA, N.; HOSODA, K.; MATSUMOTO, T.; MISE, H.; NISHIMURA, H.; YOSHIMASA, Y.; TANAKA, I.; MORI, T.; NAKAO, K. Nonadipose tissue production of leptin: Leptin as a novel placenta-derived hormone in humans. Nature Medicine, New York, v. 3, p. 1029-1033, 1997.

MEYER, C.; ROBSON, D.; RACKOVSKY, N.; NADKARNI, V.; GERICH, J.; Role of the kidney in human leptin metabolism. American Journal of Physiology, Baltimore, v. 273, p. 903-907, 1997.

MORASH, B.; LI, A.; MURPHY, P.R.; WILKINSON, M.; UR, E. Leptin gene expression in the brain and pituitary gland. Endocrinology, Lippincott, v.140, p. 5995-5998, 1999.

MOURA, A. S. A. M. T.; BOSCHIERO, C.; CAMPOS, R. L. R.; AMBO, M.; NONES, K.; LEDUR, M. C.; ROSARIO, M. F.; MELO, C. M. R.; BURT, D.W.; COUTINHO, L.L. Mapping QTL for performance and carcass traits in chicken chromosomes 6, 7, 8, 11 and 13. In: WORLD CONGRESS ON GENETICS APPLIED TO LIVESTOCK PRODUCTION, 8., 2006. Belo Horizonte: WCGALP, 2006. p. 22-50.

MUIR, W. M. Molecular genetics in poultry breeding. In: SIMPÓSIO INTERNACIONAL DE GENÉTICA E MELHORAMENTO ANIMAL. 1999, Viçosa/MG. Anais...Viçosa, 1999. p. 243-267. 
NIE, Q.; SUN, B.; ZHANG, D.; LUO, C.; ISHA,G. N.A.; LEI, M.; YANG, G.; ZHANG, X. High diversity of the chicken growth hormone gene and effects on growth and carcass traits. Journal of Heredity, Washington, v. 96, n.6, p. 698-703, 2005.

NONES, K.; LEDUR, M. C.; RUY, D. C.; BARON, E. E.; MELO, C. M. R.; MOURA, A. S. A. M. T.; ZANELLA, E. L.; BURT, D. W.; COUTINHO, L. L. Mapping QTLs on chicken chromosome 1 for performance and carcass traits in a broiler x layer cross. Animal Genetics, Oxford, v. 37, p. 95-100, 2006.

NONES, K.; LEDUR, M.C.; RUY, D.C.; BARON, E.E.; COUTINHO, L.L. Identificação de QTLs associados a peso corporal no cromossomo 1 de aves. Revista Brasileira de Ciência Avícola, Campinas, supl. 5, p. 109, 2003.

OHKUBO, T.; TANAKA, M.; NAKASHIMA, K.; Structure and tissue distribution of chicken leptin receptor (cOb-R) mRNA. Biochimica et Biophysica Acta, Amsterdam, v. 1491, p. 303308, 2000.

PASTINEN, T.; KURG A.; METSPALU, A.; PELTONEN, L.; SYVANEN, A.C. Minisequencing: a specificc tool for DNAanalysis and diagnostics on oligonucleotide arrays, Genome Research, Cold Spring Harbor, v. 7, p. 606-614, 1997.

PITEL, F; MONBRUN, C; GELLIN, J; VIGNAL, A. Mapping of the LEP (OB) gene to a chicken microchromosome. Animal Genetics, Oxford, v. 30, n. 1, p.73-74, 1999.

PITEL, F.; MONBRUN, C.; GELLIN, J.; VIGNAL, A. The chicken LEP (OB) gene has not been mapped. Animal Genetics, Oxford, v. 31, p. 281, 2000.

PLASTOW, G.S. Molecular genetics in the swine industry. In. SIMPÓSIO NACIONAL DA SBMA 3., 2000, Belo Horizonte, MG. Anais...Belo Horizonte:SBMA, 2000. p. 21-30.

ROBERT, C.M.F.; PALIN, N.; COULOMBE, C.; ROBERGE, F.G.; SILVERSIDES, B.F. BENKEL, R.M.; PELLETIER, G. Backfat thickness in pigs is positively associated with leptin mRNA levels. Canadian Journal of Animal Science, Ottawa, v. 78, p. 473-482, 1998.

RIBEIRO, A.M.L.; KESSLER, A.M.; JUNIOR, A.M.P.; KRABBE, E.L.; BRUGALLI, I.; POPHAL, S. Avaliação da monensina no desempenho e rendimento de carcaça e partes de frangos de corte. Revista Brasileira de Zootecnia, Viçosa, 29, n. 4, p. 1141-1152, 2000. 
ROBERT, C., PALIN, M.F.; COULOMBE, N.; ROBERGE, C.; SILVERSIDES, F.G.; BENKEL, B.F.; MCKAY, R.M.; PELLETIER, G. Backfat thickness in pigs is positively associated with leptin mRNA levels. Canadian Journal of Animal. Science, Otawa, v. 78, p. 473-482, 1998.

ROTHSCHILD, M.F.; LIU, H.C.; TUGGLE, C.K.; YU, T.P.; WANG, L. Analysis of pig chromosome 7 genetic markers for growth and carcass performance traits. Journal of Animal Breeding and Genetics, Berlin. v. 112, p. 341-348, 1995.

ROTHSCHILD, M. F.; SOLLER, M. Candidate gene analysis to detect traits of economic importance in domestic livestock. Probe, Ontario, v. 8, p.13-20, 1997.

ROTHSCHILD, M.F.; SOLLER, M. Candidate gene analysis to detect genes controlling of economic importance in domestic livestock. In: SIMPÓSIO INTERNACIONAL DE GENÉTICA E MELHORAMENTO ANIMAL, 1999, Viçosa, MG. Anais...Viçosa, MG: s.n, 1999. p. 218-242.

RUY, D.C.; NONES, K.; BARON, E.E.; LEDUR, M.C.; CAMPOS, R.L.R.; AMBO, M.; COUTINHO, L.L. Identificação de QTL influenciando o peso corporal no cromossomo 3 de aves (Gallus gallus). In: CONGRESSO NACIONAL DE GENÉTICA, 49., 2003. Águas de Lindóia, SP. Resumos... Ribeirão Preto: Sociedade Brasileira de Genética, 2003.1 CD-ROM.

SAS INSTIUTE INC, System for Microsoft Windows, Release 8.2, Cary, NC, USA, 2002.

SCHMID, M.; NANDA, I.; HOEHN, H.; SCHARTL, M.; HAAF, T.; BUERSTEDDE, J. M.; ARAKAWA, H.; CALDWELL, R. B.; WEIGEND, S.; BURT, D. W.; SMITH, J.; GRIFFIN, D. K.; MASABANDA, J. S.; GROENEN, M. A.; CROOIJMANS, R. P.; VIGNAL, A.; FILLON, V.; MORISSON, M.; PITEL, F.; VIGNOLES, M.; GARRIGUES, A.; GELLIN, J.; RODIONOV, A. V.; GALKINA, S. A.; LUKINA, N. A.; BEN-ARI, G.; BLUM, S.; HILLEL, J.; TWITO, T.; LAVI, U.; DAVID, L.; FELDMAN, M. W.; DELANY, M. E.; CONLEY, C. A.; FOWLER, V. M.; HEDGES, S. B.; GODBOUT, R.; KATYAL, S.; SMITH, C.; HUDSON, Q.; SINCLAIR, A.; MIZUNO, S.; Second report on chicken genes and chromosomes 2005. Cytogenetic and Genome Research, Basel, v. 109, n. 4, p.415-479, 2005.

SOUZA, C. A; LEDUR, M. C; COUTINHO, L.L. Avaliação do efeito de polimorfismos nos genes da miostatina, myod e miogenina em características quantitativas de desempenho e carcaça em Gallus gallus. In CONGRESSO BRASILEIRO DE GENÉTICA, 51., 2005, Águas de Lindóia. SP. Resumos... Ribeirão Preto. Sociedade Brasileira de Genética, 2005.1 CD-ROM. 
STRINGHINI, J.H.; LABOISSIÉRE, M.; MURAMATSU, K.; LEANDRO, N.S.M.; CAFÉ, M. B. Avaliação do desempenho e rendimento de carcaça de quatro linhagens de frangos de corte criadas em Goiás. Revista Brasileira de Zootecnia, Viçosa, v. 32, n.1, p.183-190, 2003.

TARTAGLIA, L.A.; DEMBSKI, M.; WENG, X.; DENG, N.; CULPEPPER, J.; DEVOS, R.; RICHARDS, G. J; CAMPFIELD, L.A.; CLARK, F.T.; DEEDS, J.; MUIR, C.; SANKER, S.; MORIARTY, A.; MOORE, K.J.; SMUTKO, J.S.; MAYS, E.A.; WOOLF, E.A.; MONROE, C.A.; TEPPER, R.I. Identification and expression cloning of a leptin receptor, OB-R. Cell, Cambridge, v.83, p.1263-1271, 1995.

TAOUIS, M.; CHEN, J. W.; DAVIAUD C.; DUPONT, J.; DEROUET, M.; SIMON, J. Cloning the chicken leptin gene. Gene, Amsterdam, v. 208, p.239-242, 1998.

UNIÃO BRASILEIRA DE AVICULTURA. Relatório Anual 2005/2006. Brasília - DF, 2006. $76 \mathrm{p}$.

VINCENT, A. L.; WANG, L.; ROTHSCHILD, M.F. Rapid communication: a restriction fragment length polymorphism in the porcine leptin receptor (LEPR) gene. Journal of Animal Science, Albany, v. 75, p. 2287, 1997.

VOORRIPS, R.E. MapChart: Software for the graphical presentation of linkage maps and QTLs. The Journal of Heredity, Oxford, v.93, n.1, p.77-78. 2002.

WANG, J.; HE, X.; RUAN, J.; DAI, M.; CHEN, J.; ZHANG, Y.; HU, Y.; YE, C.; LI, S.; CONG, L.; FANG, L.; LIU, B.; LI, S.; WANG, J.; BURT, D. W.; WONG, G. K.; YU, J.; YANG, H.; WANG, J. ChickVD: a sequence variation database for the chicken genome Nucleic Acids Research, London, v. 33, p. 438-441, 2004.

WANG, Q.; LI, H.; LI, N.; LENG, L.; WANG, Y.; TANG, Z.; Identification of single nucleotide polymorphism of adipocyte fatty acid-binding protein gene and its association with fatness traits in the chicken. Poultry Science, Ithaca, v. 85, n. 3, p.429-434, 2006.

WANG, Y., LI, H. GU, Z.L., ZHAO, J.G., WANG, Q.G., WANG, Y.X. [Correlation analysis between single nucleotide polymorphism of the leptin receptor intron 8 and fatness traits in chickens]. Yi Chuan Xue Bao, v. 31, n. 3, p.265, 2004. 
WONG, G.K; LIU, B; WANG, J.; ZHANG, Y.; YANG, X.; ZHANG, Z.; MENG, Q.; ZHOU, J.; LI, D.; ZHANG, J.; NI , LI S, RAN L, LI H, ZHANG J, LI R, LI S, ZHENG H, LIN W, LI G, WANG X, ZHAO W, LI J, YE C, DAI M, RUAN J, ZHOU Y, LI Y, HE X, ZHANG Y, HUANG X, TONG W, CHEN J, YE J, CHEN C, WEI N, LI G, DONG L, LAN F, SUN Y, ZHANG Z, YANG Z, YU Y, HUANG Y, HE D, XI Y, WEI D, QI Q, LI W, SHI J, WANG M, XIE F, WANG J, ZHANG X, WANG P, ZHAO Y, LI N, YANG N, DONG W, HU S, ZENG C, ZHENG W, HAO B, HILLIER LW, YANG SP, WARREN WC, WILSON RK, BRANDSTROM M, ELLEGREN H, CROOIJMANS RP, VAN DER POEL JJ, BOVENHUIS H, GROENEN MA, OVCHARENKO I, GORDON L, STUBBS L, LUCAS S, GLAVINA T, AERTS A, KAISER P, ROTHWELL L, YOUNG JR, ROGERS S, WALKER BA, VAN HATEREN A, KAUFMAN J, BUMSTEAD N, LAMONT SJ, ZHOU H, HOCKING PM, MORRICE D, DE KONING DJ, LAW A, BARTLEY N, BURT DW, HUNT H, CHENG HH, GUNNARSSON U, WAHLBERG P, ANDERSSON L, KINDLUND E, TAMMI MT, ANDERSSON B, WEBBER C, PONTING CP, OVERTON IM, BOARDMAN PE, TANG H, HUBBARD SJ, WILSON SA, YU J, WANG J, YANG H; International Chicken Polymorphism Map Consortium. A genetic variation map for chicken with 2.8 million single-nucleotide polymorphisms. Nature, London, v. 432, n. 7018, p. 717-722, Dec. 2004.

VIGNAL, A.; MILAN, D.; SANCRISTOBAL, M.; EGGEN, A. A review on SNP and other types of molecular markers and their use in animal genetics. Genetics Selection Evolution, Paris, v.34, p.275-305, 2002.

VILÀ, R.; ADÁN, C.; RAFECAS, I.; FERNÁNDEZ-LOPES, J.A.; REMESAR, X.; ALEMANY, M. Plasma leptin turnover rates in lean and obese Zucker rats. Endocrinology, Lippincott; v.139, p.4466-4469, 1998.

ZHANG, Y.; PROENÇA, R.; MAFFEI, M.; BARONE, M.; LEOPOLD, L.; FRIEDMAN, J.M. Positional cloning of the mouse obese gene and its human homologue. Nature, London; v. 372, p.425-432, 1994. 
ANEXO 
ANEXO A - Polimorfismos no íntron 8 do gene do receptor da leptina detectados nas linhagens TT e CC. A posição dos polimorfismos está descrita em relação à seqüência do GenBank AF222783

\begin{tabular}{|c|c|c|c|c|c|}
\hline Posição & Indivíduo & Linhagem & Nucleotídeo Consenso & Nucleotídeo Mutante & Genótipo \\
\hline 218 & 5921 & TT & $\mathrm{T}$ & $\mathrm{C}$ & TC \\
\hline 229 & 5921 & TT & $\mathrm{T}$ & A & AA \\
\hline 320 & 5921 & TT & A & G & AG \\
\hline 336 & 241 & CC & $\mathrm{T}$ & $\mathrm{C}$ & $\mathrm{TC}$ \\
\hline 336 & 886 & CC & $\mathrm{T}$ & C & CC \\
\hline 336 & 88 & CC & $\mathrm{T}$ & C & CC \\
\hline 336 & 5921 & $\mathrm{TT}$ & $\mathrm{T}$ & C & TC \\
\hline 352 & 6037 & TT & $\mathrm{C}$ & $\mathrm{T}$ & TT \\
\hline 352 & 5649 & TT & $\mathrm{C}$ & $\mathrm{T}$ & TT \\
\hline 352 & 5661 & TT & $\mathrm{C}$ & $\mathrm{T}$ & TT \\
\hline 352 & 5921 & TT & $\mathrm{C}$ & $\mathrm{T}$ & CT \\
\hline 352 & 5561 & TT & $\mathrm{C}$ & $\mathrm{T}$ & TT \\
\hline 352 & 6232 & TT & $\mathrm{C}$ & $\mathrm{T}$ & TT \\
\hline 421 & 37 & CC & G & C & GC \\
\hline 421 & 570 & $\mathrm{CC}$ & G & $\mathrm{C}$ & GC \\
\hline 427 & 241 & CC & A & G & AG \\
\hline 427 & 886 & CC & A & G & GG \\
\hline 427 & 88 & CC & A & G & GG \\
\hline 427 & 5921 & $\mathrm{TT}$ & A & G & AG \\
\hline 427 & 37 & CC & A & G & AG \\
\hline 427 & 570 & CC & A & G & $\mathrm{AG}$ \\
\hline 502 & 5921 & $\mathrm{TT}$ & $\mathrm{T}$ & C & $\mathrm{TC}$ \\
\hline 508 & 241 & CC & $\mathrm{T}$ & $\mathrm{C}$ & $\mathrm{TC}$ \\
\hline 508 & 886 & $\mathrm{CC}$ & $\mathrm{T}$ & $\mathrm{C}$ & $\mathrm{CC}$ \\
\hline 508 & 88 & $\mathrm{CC}$ & $\mathrm{T}$ & $\mathrm{C}$ & $\mathrm{CC}$ \\
\hline 523 & 241 & $\mathrm{CC}$ & G & A & GA \\
\hline 523 & 886 & $\mathrm{CC}$ & G & A & AA \\
\hline 523 & 88 & $\mathrm{CC}$ & G & A & AA \\
\hline 660 & 6037 & TT & A & G & GG \\
\hline 660 & 5649 & TT & A & G & GG \\
\hline 660 & 5661 & TT & A & G & GG \\
\hline 660 & 5921 & TT & A & G & AG \\
\hline 660 & 5561 & TT & A & G & GG \\
\hline 660 & 6232 & TT & A & G & GG \\
\hline 733 & 5921 & TT & $\mathrm{T}$ & A & AA \\
\hline
\end{tabular}


ANEXO B - Polimorfismos no íntron 8 do gene do receptor da leptina detectados na geração F1. A posição dos polimorfismos está descrita em relação à seqüência do GenBank AF222783

(continua)

\begin{tabular}{|c|c|c|c|c|c|}
\hline Posição & Indivíduo & Linhagem & Nucleotídeo Consenso & Nucleotídeo Mutante & Genótipo \\
\hline 218 & 7975 & TC & $\mathrm{T}$ & $\mathrm{C}$ & TC \\
\hline 218 & 7971 & TC & $\mathrm{T}$ & $\mathrm{C}$ & $\mathrm{TC}$ \\
\hline 229 & 7975 & TC & $\mathrm{T}$ & A & AA \\
\hline 229 & 7971 & TC & $\mathrm{T}$ & A & AA \\
\hline 320 & 7975 & TC & A & G & AG \\
\hline 320 & 7971 & TC & A & G & AG \\
\hline 336 & 7977 & TC & $\mathrm{T}$ & $\mathrm{C}$ & TC \\
\hline 336 & 7755 & TC & $\mathrm{T}$ & $\mathrm{C}$ & TC \\
\hline 336 & 7716 & TC & $\mathrm{T}$ & $\mathrm{C}$ & TC \\
\hline 336 & 7722 & TC & $\mathrm{T}$ & $\mathrm{C}$ & TC \\
\hline 336 & 7769 & TC & $\mathrm{T}$ & $\mathrm{C}$ & TC \\
\hline 336 & 7765 & TC & $\mathrm{T}$ & $\mathrm{C}$ & $\mathrm{TC}$ \\
\hline 336 & 7771 & TC & $\mathrm{T}$ & $\mathrm{C}$ & TC \\
\hline 336 & 7975 & TC & $\mathrm{T}$ & $\mathrm{C}$ & TC \\
\hline 336 & 7971 & TC & $\mathrm{T}$ & $\mathrm{C}$ & TC \\
\hline 352 & 7977 & TC & $\mathrm{C}$ & $\mathrm{T}$ & $\mathrm{CT}$ \\
\hline 352 & 7978 & TC & $\mathrm{C}$ & $\mathrm{T}$ & $\mathrm{CT}$ \\
\hline 352 & 7755 & TC & C & $\mathrm{T}$ & CT \\
\hline 352 & 7749 & TC & $\mathrm{C}$ & $\mathrm{T}$ & $\mathrm{CT}$ \\
\hline 352 & 7716 & TC & C & $\mathrm{T}$ & $\mathrm{CT}$ \\
\hline 352 & 7722 & TC & $\mathrm{C}$ & $\mathrm{T}$ & CT \\
\hline 352 & 7769 & TC & C & $\mathrm{T}$ & CT \\
\hline 352 & 7765 & TC & $\mathrm{C}$ & $\mathrm{T}$ & CT \\
\hline 352 & 7771 & TC & C & $\mathrm{T}$ & $\mathrm{CT}$ \\
\hline 352 & 7975 & TC & $\mathrm{C}$ & $\mathrm{T}$ & $\mathrm{CT}$ \\
\hline 352 & 7971 & TC & $\mathrm{C}$ & $\mathrm{T}$ & CT \\
\hline 352 & 7972 & TC & $\mathrm{C}$ & $\mathrm{T}$ & CT \\
\hline 352 & 7797 & TC & $\mathrm{C}$ & $\mathrm{T}$ & CT \\
\hline 352 & 7798 & TC & $\mathrm{C}$ & $\mathrm{T}$ & $\mathrm{CT}$ \\
\hline 352 & 7709 & TC & $\mathrm{C}$ & $\mathrm{T}$ & $\mathrm{CT}$ \\
\hline 352 & 7713 & TC & C & $\mathrm{T}$ & $\mathrm{CT}$ \\
\hline 352 & 7822 & TC & $\mathrm{C}$ & $\mathrm{T}$ & CT \\
\hline 352 & 7810 & TC & $\mathrm{C}$ & $\mathrm{T}$ & CT \\
\hline 352 & 7812 & TC & $\mathrm{C}$ & $\mathrm{T}$ & $\mathrm{CT}$ \\
\hline 352 & 7816 & TC & $\mathrm{C}$ & $\mathrm{T}$ & CT \\
\hline 421 & 7797 & TC & G & $\mathrm{C}$ & GC \\
\hline 421 & 7709 & TC & $\mathrm{G}$ & $\mathrm{C}$ & GC \\
\hline 427 & 7977 & TC & A & G & AG \\
\hline 427 & 7755 & TC & A & G & AG \\
\hline 427 & 7716 & TC & A & G & AG \\
\hline 427 & 7722 & TC & A & G & $A G$ \\
\hline 427 & 7769 & TC & A & G & AG \\
\hline 427 & 7765 & TC & A & G & AG \\
\hline 427 & 7771 & TC & A & G & AG \\
\hline
\end{tabular}


ANEXO B - Polimorfismos no íntron 8 do gene do receptor da leptina detectados na geração F1. A posição dos polimorfismos está descrita em relação à seqüência do GenBank AF222783

(conclusão)

\begin{tabular}{|c|c|c|c|c|c|}
\hline Posição & Indivíduo & Linhagem & Nucleotídeo Consenso & Nucleotídeo Mutante & Genótipo \\
\hline 427 & 7975 & TC & $\mathrm{A}$ & $\mathrm{G}$ & GG \\
\hline 427 & 7971 & TC & A & G & AG \\
\hline 427 & 7972 & TC & A & G & AG \\
\hline 427 & 7797 & TC & A & G & AG \\
\hline 427 & 7709 & TC & A & G & AG \\
\hline 502 & 7975 & TC & $\mathrm{T}$ & $\mathrm{C}$ & TC \\
\hline 502 & 7971 & TC & $\mathrm{T}$ & $\mathrm{C}$ & TC \\
\hline 508 & 7977 & TC & $\mathrm{T}$ & $\mathrm{C}$ & TC \\
\hline 508 & 7755 & TC & $\mathrm{T}$ & $\mathrm{C}$ & TC \\
\hline 508 & 7716 & TC & $\mathrm{T}$ & $\mathrm{C}$ & TC \\
\hline 508 & 7722 & TC & $\mathrm{T}$ & $\mathrm{C}$ & TC \\
\hline 508 & 7769 & TC & $\mathrm{T}$ & C & TC \\
\hline 508 & 7765 & TC & $\mathrm{T}$ & $\mathrm{C}$ & TC \\
\hline 508 & 7771 & TC & $\mathrm{T}$ & C & TC \\
\hline 523 & 7977 & TC & G & A & GA \\
\hline 523 & 7755 & TC & G & A & GA \\
\hline 523 & 7716 & TC & G & A & GA \\
\hline 523 & 7722 & TC & G & A & GA \\
\hline 523 & 7769 & TC & G & A & GA \\
\hline 523 & 7765 & TC & G & A & GA \\
\hline 523 & 7972 & TC & G & A & GA \\
\hline 660 & 7977 & TC & A & G & AG \\
\hline 660 & 7978 & TC & A & G & AG \\
\hline 660 & 7755 & TC & A & G & AG \\
\hline 660 & 7749 & TC & A & G & AG \\
\hline 660 & 7716 & TC & A & G & AG \\
\hline 660 & 7722 & TC & A & G & AG \\
\hline 660 & 7769 & TC & A & G & AG \\
\hline 660 & 7765 & TC & A & G & AG \\
\hline 660 & 7771 & TC & A & G & AG \\
\hline 660 & 7972 & TC & A & G & AG \\
\hline 660 & 7797 & TC & A & G & AG \\
\hline 660 & 7798 & TC & A & G & AG \\
\hline 660 & 7709 & TC & A & G & AG \\
\hline 660 & 7713 & TC & A & G & AG \\
\hline 660 & 7822 & TC & A & G & AG \\
\hline 660 & 7810 & TC & A & G & AG \\
\hline 660 & 7812 & TC & A & G & AG \\
\hline 660 & 7816 & TC & A & G & AG \\
\hline 733 & 7975 & TC & $\mathrm{T}$ & A & TA \\
\hline 733 & 7971 & TC & $\mathrm{T}$ & A & TA \\
\hline
\end{tabular}


ANEXO C - Polimorfismos no íntron 19 do gene do receptor da leptina detectados nas linhagens TT e CC. A posição dos polimorfismos está descrita em relação à seqüência GenBank AY348718S2

\begin{tabular}{cccccc}
\hline Posição Consenso & Indivíduo & Linhagem & Nucleotídeo Consenso & Nucleotídeo Mutante & Genótipo \\
\hline 326 & 886 & CC & G & A & AA \\
326 & 88 & CC & G & A & AA \\
326 & 241 & CC & G & A & GA \\
440 & 886 & CC & G & A & AA \\
440 & 88 & CC & G & A & AA \\
440 & 241 & CC & G & A & GA \\
633 & 5561 & TT & GGAAG & Deleção & Deleção \\
633 & 5649 & TT & GGAAG & Deleção & Delecão \\
633 & 5661 & TT & GGAAG & Deleção & Delecão \\
633 & 5921 & TT & GGAAG & Deleção & Deleção \\
633 & 6037 & TT & GGAAG & Deleção & Deleção \\
633 & 6232 & TT & GGAAG & Deleção & Deleção \\
633 & 570 & CC & GGAAG & Deleção & Delecãa \\
633 & 37 & CC & GGAAG & Deleção & Deleção \\
633 & 332 & CC & GGAAG & Deleção & Deleção \\
646 & 886 & CC & T & C & CC \\
646 & 88 & CC & T & C & CC \\
915 & 570 & CC & G & A & AA \\
915 & 37 & CC & G & A & AA \\
927 & 570 & CC & G & T & TT \\
927 & 37 & CC & G & T & TT \\
927 & 332 & CC & G & C & CC \\
\hline
\end{tabular}


ANEXO D - Polimorfismos no íntron 19 do gene do receptor da leptina detectados na geração F1. A posição dos polimorfismos está descrita em relação à seqüência do GenBank AY348718S2

\begin{tabular}{|c|c|c|c|c|c|}
\hline Posição & Indivíduo & Linhagem & Nucleotídeo Consenso & Nucleotídeo Mutante & Genótipo \\
\hline 326 & 7716 & TC & G & A & GA \\
\hline 326 & 7722 & TC & G & A & GA \\
\hline 326 & 7765 & TC & G & A & GA \\
\hline 326 & 7769 & TC & G & A & GA \\
\hline 326 & 7971 & TC & G & A & GA \\
\hline 440 & 7716 & TC & G & A & GA \\
\hline 440 & 7722 & TC & G & A & GA \\
\hline 440 & 7765 & TC & G & A & GA \\
\hline 440 & 7769 & TC & G & A & GA \\
\hline 440 & 7971 & TC & G & A & GA \\
\hline 633 & 7709 & TC & GGAAG & Deleção & Deleção \\
\hline 633 & 7713 & TC & GGAAG & Deleção & Deleção \\
\hline 633 & 7716 & TC & GGAAG & Deleção & GGAAG/Del \\
\hline 633 & 7722 & TC & GGAAG & Deleção & GGAAG/Del \\
\hline 633 & 7749 & TC & GGAAG & Deleção & Deleção \\
\hline 633 & 7755 & TC & GGAAG & Deleção & Deleção \\
\hline 633 & 7765 & TC & GGAAG & Deleção & GGAAG/Del \\
\hline 633 & 7769 & TC & GGAAG & Deleção & GGAAG/Del \\
\hline 633 & 7771 & TC & GGAAG & Deleção & Deleção \\
\hline 633 & 7797 & TC & GGAAG & Deleção & Deleção \\
\hline 633 & 7798 & TC & GGAAG & Deleção & Deleção \\
\hline 633 & 7810 & TC & GGAAG & Deleção & Deleção \\
\hline 633 & 7812 & TC & GGAAG & Deleção & Deleção \\
\hline 633 & 7816 & TC & GGAAG & Deleção & Deleção \\
\hline 633 & 7822 & TC & GGAAG & Deleção & Deleção \\
\hline 633 & 7972 & TC & GGAAG & Deleção & Deleção \\
\hline 633 & 7975 & TC & GGAAG & Deleção & Deleção \\
\hline 633 & 7977 & TC & GGAAG & Deleção & Deleção \\
\hline 633 & 7978 & TC & GGAAG & Deleção & Deleção \\
\hline 646 & 7716 & TC & $\mathrm{T}$ & C & CT \\
\hline 646 & 7722 & TC & $\mathrm{T}$ & $\mathrm{C}$ & CT \\
\hline 646 & 7765 & TC & $\mathrm{T}$ & $\mathrm{C}$ & CT \\
\hline 646 & 7769 & TC & $\mathrm{T}$ & $\mathrm{C}$ & CT \\
\hline 915 & 7709 & TC & G & A & AG \\
\hline 915 & 7797 & TC & G & A & AG \\
\hline 915 & 7972 & TC & G & A & AG \\
\hline 915 & 7975 & TC & G & A & AA \\
\hline 927 & 7709 & TC & G & T e C & $\mathrm{TT}$ \\
\hline 927 & 7971 & TC & G & T e C & GT \\
\hline 927 & 7975 & TC & G & T e C & GT \\
\hline
\end{tabular}

